\title{
46. INORGANIC AND ORGANIC GEOCHEMISTRY OF EOCENE TO CRETACEOUS STRATA RECOVERED FROM THE LOWER CONTINENTAL RISE, NORTH AMERICAN BASIN, SITE 603, DEEP SEA DRILLING PROJECT LEG 93
}

\author{
Walter E. Dean, U.S. Geological Survey, Denver, Colorado \\ and \\ Michael A. Arthur, University of Rhode Island ${ }^{2}$
}

\begin{abstract}
About one hundred samples of sediments and rocks recovered in Hole 603B were analyzed for type, abundance, and isotopic composition of organic matter, using a combination of Rock-Eval pyrolysis, $\mathrm{C}-\mathrm{H}-\mathrm{N}-\mathrm{S}$ elemental analysis, and isotope-ratio mass spectrometry. Concentrations of major, minor, and trace inorganic elements were determined with a combination of X-ray fluorescence and induction-coupled plasma spectrometry.

The oldest strata recovered in Hole 603B (lithologic Unit V) consist of interbedded light-colored limestones and marlstones, and black calcareous claystones of Neocomian age. The inorganic and organic geochemical results suggest a very terrigenous aspect to the black claystones. The organic geochemical results indicate that the limestones and marlstones contain a mixture of highly degraded marine and terrestrial organic matter. Comparison of the Neocomian carbonates at Site 603 with those on the other side of the North Atlantic, off Northwest Africa at Site 367, shows that the organic matter at Site 367 contains more marine organic matter, as indicated by higher pyrolysis hydrogen indices and lighter values of $\delta^{13} \mathrm{C}$. Comparison of inorganic geochemical results for the carbonate lithologies at Site 603 with those for carbonate lithologies at Site 367 suggests that the Site 603 carbonates may contain clastic material from both North American and African sources. The black claystones at Site 603, on the other hand, probably were derived almost entirely from North American clastic sources.

Lithologic Unit IV overlying the Neocomian carbonates, consists of interbedded red, green, and black claystones. The black claystones at Site 603 contain more than ten times the organic carbon concentration of the interbedded green claystones. The average concentration of organic carbon in the black claystones $(2.8 \%)$, however, is low relative to most mid-Cretaceous black claystones and shales in the Atlantic, particularly those found off Northwest Africa. The geochemical data all suggest that the organic matter in the black claystones is more abuhdant but generally more degraded than the organic matter in the green claystones, and that it was derived mainly from terrestrial sources and deposited in oxygenated bottom waters. The increased percentage of black claystone beds in the upper Cenomanian section, and the presence of more hydrogen-rich organic matter in this part of the section, probably resulted from the increased production and accumulation of marine organic matter that is represented worldwide near the Cenomanian/Turonian boundary in deep-sea and land sections. A few upper Cenomanian black claystone samples that have hydrogen indices $>150$ also contain particularly high concentrations of $\mathrm{V}$ and $\mathrm{Zn}$. Most samples of black claystone, however, are not particularly metal-rich compared with other black claystones and shales. Compared with red claystones from lithologic Unit IV, the green and black claystones are enriched in many trace transition elements, especially $\mathrm{V}, \mathrm{Zn}, \mathrm{Cu}, \mathrm{Co}$, and $\mathrm{Pb}$.

The main difference between the "carbonaceous" claystones of lithologic Unit IV and "variegated" or "multicolored" claystones of the overlying Upper Cretaceous to lower Tertiary Unit III is the absence of black claystone beds. As observed at several other sites (105 and 386), the multicolored claystones at Site 603 are somewhat enriched in several trace transition elements-especially $\mathrm{Cu}, \mathrm{Ni}$, and $\mathrm{Cr}$-relative to most deep-sea clays. The multicolored claystones are not enriched in Fe and Mn, and therefore are not "metalliferous" sediments in the sense of those found at several locations in the eastern Pacific. The source of the slightly elevated concentrations of transition metals in the multicolored claystones probably is upward advection and diffusion of metals from the black claystones of the underlying Hatteras Formation.

The red, orange, and green claystone beds of lithologic Unit II (Eocene), like those of Unit III, really represent a continuation of deposition of multicolored claystone that began after the deposition of the Neocomian carbonates. The color of the few black beds that occur within this unit results from high concentrations of manganese oxide rather than high concentrations of organic matter.
\end{abstract}

\section{INTRODUCTION}

Most of the Jurassic to Pleistocene sections recovered at DSDP sites in the North Atlantic consist of cyclically interbedded strata in which the main differences between the interbeds are in color, the amount of organic matter,

\footnotetext{
${ }^{1}$ van Hinte, J. E., Wise, S. W., Jr., et al., Init. Repts. DSDP, 93: Washington (U.S. Govt, Printing Office),

2 Addresses: (Dean) U.S. Geological Survey, Denver, CO 80225; (Arthur) Graduate School of Oceanography, University of Rhode Island, Narragansett, RI 02882.
}

and (or), for carbonate strata, the amount of insoluble residue (Dean et al., 1978; Jansa et al., 1978, 1979; McCave, 1979a; Dean and Gardner, 1982; Arthur and Dean, 1986). The primary causes of the cyclicity were variations in one or more of the following depositional conditions: the position of the calcite compensation depth (CCD), influx of terrigenous clastic material, influx of terrestrial and marine organic matter, and redox conditions in the bottom waters and sediments. The ultimate driving force for the cyclic depositional patterns, however, was probably external to the depositional basins and related to cyclic variations in global climate. Be- 
cause estimates of the periodicities of these cyclic interbeds generally fall within the range of 20 to $100 \mathrm{ky}$. (e.g., Dean et al., 1978; McCave, 1979a; Dean and Gardner, 1982; Arthur, Dean, Bottjer, et al., 1984), it has been suggested that this cyclicity may be related to cyclic variations in insolation-resulting from changes in the Earth's orbital parameters (the so-called Milankovitch Cycles)that have periodicities within the same range (e.g., Schwarzacher and Fischer, 1982; Arthur, Dean, Bottjer, et al., 1984). Superimposed on these cyclic patterns, and sometimes accentuating them, are strata of reworked material introduced by slumping, turbidity currents, and debris flows (Dean et al., 1978; McCave, 1979a, b; Kelts and Arthur, 1981; Summerhayes, 1981; de Graciansky et al., 1982; Dean and Gardner, 1982; Summerhayes and Masran, 1983; Robertson and Bliefnick, 1983; Arthur, Dean, and Stow, 1984). All these cyclic depositional features are particularly well displayed in Hole 603B (Fig. 1). The sedimentary section recovered in Hole 603B has the regional depositional characteristics that prompted Jansa et al. (1979) to define formations for the entire North Atlantic (Fig. 2), but also has a considerable amount of reworked material derived from the continental margin of North America.

This investigation is part of our ongoing investigation of cyclic sedimentation in the oceans through time, particularly cyclic organic carbon (OC) accumulation in Mesozoic and Cenozoic strata in the North Atlantic. For this investigation we have used measurements of type, abundance, and isotopic composition of organic matter, and elemental concentrations in Cretaceous to Eocene rocks recovered in Hole $603 \mathrm{~B}$, all tied to the basic stratigraphic and sedimentologic framework (Fig. 2; Site 603 chapter, this volume). Samples were collected for inorganic and organic geochemical analyses from Hole 603B to characterize the Eocene radiolarian claystones of lithologic Unit II, the Upper Cretaceous multicolored claystones of lithologic Unit III, the mid-Cretaceous black carbonaceous claystones of lithologic Unit IV, and the Lower Cretaceous (Neocomian) limestones and marlstones of lithologic Unit V (Fig. 2); 63 samples were collected on board the Glomar Challenger, and an additional 39 samples from lithologic Units IV and V were collected after the cruise (Tables 1 and 2).

\section{METHODS}

The samples were air-dried and ground to pass a 100-mesh (149- $\mu \mathrm{m})$ sieve. Eleven of the samples were chosen at random for duplicate analyses. Inorganic geochemical analyses were performed on 112 samples (101 samples plus 11 duplicates) at the U.S. Geological Survey (U.S.G.S.), Denver. Twenty-six samples of green and black claystones from lithologic Unit IV and 26 samples of Neocomian carbonates from lithologic Unit V were submitted for Rock-Eval pyrolysis and measurement of stable carbon-isotope ratios of organic carbon (OC) at the U.S.G.S. laboratories in Denver. Splits of shipboard samples were sent to the University of Michigan for analyses of carbon and nitrogen, and splits of all samples were sent to the University of Rhode Island for analyses of carbon, nitrogen, and sulfur by $\mathrm{C}-\mathrm{H}-\mathrm{N}$ (see $\mathrm{Ar}-$ thur et al., this volume, for specific methods and comparison of results). Unless otherwise specified, all $\mathrm{OC}$ concentrations are given on a whole-rock rather than a carbonate-free basis. Splits of some samples also were sent to the University of Illinois for measurement of stable sulfur-isotope ratios (see Bonnell and Anderson, this volume).
All samples were analyzed for 40 major, minor, and trace elements by induction-coupled, argon-plasma emission spectrometry (ICP; Floyd et al., 1980). Thirty elements were detected in at least some of the samples. The following 10 elements (and their lower limits of detection, in parts per million, given in parentheses after the element) were analyzed by ICP but not detected in any of the samples: Ag (4), As (20), $\mathrm{Au}(20), \mathrm{Bi}(20), \mathrm{Cd}(4), \mathrm{Sn}(40), \mathrm{U}(200), \mathrm{Ta}(80), \mathrm{Eu}(4)$, and Ho (8). The shipboard samples also were analyzed for 10 major and minor elements by X-ray fluorescence spectrometry (XRF; Taggert et al., 1980).

The Rock-Eval pyrolysis method provides a rapid determination of the hydrocarbon-generating potential and degree of preservation of sedimentary organic matter (Espitalié et al., 1977). Programmed heating of a sample in a helium atmosphere results in generation of hydrocarbons and $\mathrm{CO}_{2}$. The instrument was calibrated by analysis of reference rock samples, a synthetic standard $\left(n-\mathrm{C}_{20} \mathrm{H}_{42}\right)$, and $\mathrm{CO}_{2}$ gas. The generated hydrocarbons are measured with a flame ionization detector. Free or adsorbed hydrocarbons are liberated by heating the sample in flowing helium at relatively low temperature $\left(250^{\circ} \mathrm{C}\right)$ for $5 \mathrm{~min}$., and the yield is recorded as the area under the first peak on a pyrogram ( $S_{l} ; \mathrm{mg} \mathrm{HC} / \mathrm{g}$ sample). The $S_{l}$ peak is roughly proportional to the content of organic compounds that can be extracted from the rock or sediment with organic solvents. The second peak represents pyrolytic hydrocarbons generated by thermal breakdown of kerogen, and to a small degree by the cracking of resins and asphaltenes, as the sample is heated from 250 to $550^{\circ} \mathrm{C}$ at $25^{\circ}$ per minute $\left(S_{2} ; \mathrm{mg} \mathrm{HC} / \mathrm{g} \mathrm{sam}\right.$ ple). $\mathrm{CO}_{2}$ also is generated by kerogen degradation, and is retained during the heating interval from 250 to $390^{\circ} \mathrm{C}$ and analyzed as the integrated area under the third peak on the pyrogram $\left(S_{3} ; \mathrm{mg} \mathrm{CO} / \mathrm{g}\right.$ sample). Our data are expressed in terms of a hydrogen index (HI), which is the $S_{2}$ peak normalized to the OC content of the sample (mg $\mathrm{HC} / \mathrm{g} \mathrm{OC}$ ); an oxygen index (OI), which is the $S_{3}$ peak normalized to the $\mathrm{OC}$ content of the sample (mg HC/g OC); an oxygen index (OI), which is the $S_{3}$ peak normalized to the OC content of the sample (mg $\mathrm{CO}_{2} / \mathrm{g} \mathrm{OC}$ ); a transformation ratio or production index [PI $=S_{l}$ l $\left(S_{I}+S_{2}\right)$ ], and a temperature of maximum yield of pyrolytic hydrocarbons $\left(T_{\max }\right)$ (Tissot and Welte, 1978). The quantity $S_{l}+S_{2}$, the sum of the free and adsorbed hydrocarbons plus pyrolyzable hydrocarbons, is called the genetic potential of a sample, expressed as $\mathrm{mg} \mathrm{HC} / \mathrm{g} \mathrm{sam-}$ ple, or in equivalent units of $\mathrm{kg} \mathrm{HC}$ per metric ton of rock or parts per thousand hydrocarbons in the rock. The production index (PI) and $T_{\max }$ both have been interpreted as measures of thermal maturity (Tissot and Welte, 1978).

Katz (1983) suggested that there may be some $\mathrm{CO}_{2}$ yield from the breakdown of the carbonate minerals that could affect the OI in finegrained carbonate-rich sediments and rocks. The temperature range over which the evolved $\mathrm{CO}_{2}$ is collected $\left(250-390^{\circ} \mathrm{C}\right)$ is, however, well below the temperature of thermal dissociation of carbonate minerals. We believe that much of what has been attributed to "matrix effects" in pyrolysis analysis actually results from nonlinear response of the pyrolysis apparatus, particularly for samples that contain $<0.2 \%$ OC. The Rock-Eval pyrolysis $\mathrm{HI}$ and $\mathrm{OI}$ correlate well with atomic $\mathrm{H} / \mathrm{C}$ and $\mathrm{O} / \mathrm{C}$ ratios measured in the same samples by other methods (Espitalié et al., 1977; Tissot and Welte, 1978), and HI and OI usually can be converted to $\mathrm{H} / \mathrm{C}$ and $\mathrm{O} / \mathrm{C}$ ratio of kerogen with an accuracy of 5 to $10 \%$ (Orr, 1981, 1983).

Stable carbon-isotope ratios were determined by standard techniques (Kaplan et al., 1970; Pratt and Threlkeld, 1984). Powdered samples were oven-dried at $40^{\circ} \mathrm{C}$ and reacted with $0.5 \mathrm{~N} \mathrm{HCl}$ for $24 \mathrm{hrs}$. to dissolve carbonate minerals. If all the carbonate was not removed by the first acid leach, the sample was reacted with acid for an additional 24-hr. period. The residue was centrifuged, decanted, washed three times with deionized water, dried under flowing nitrogen at $50^{\circ} \mathrm{C}$, and combusted at $1000^{\circ} \mathrm{C}$ under oxygen pressure in a LECO induction furnace. The resulting $\mathrm{CO}_{2}$ was dehydrated and purified in a high-vacuum gas-transfer system, and the isotope ratios were determined with a Finnigan MAT 251 6-in., $90^{\circ}$-sector, isotope-ratio mass spectrometer. Results are reported in the usual per mil $\delta$-notation relative to the Peedee belemnite marine-carbonate standard (PDB):

$$
\delta^{13} \mathrm{C}(\%)=\left[\left(R_{\text {sample }} / R_{P D B}\right)-1\right] \times 10^{3}
$$

where $R$ is the ratio ${ }^{13} \mathrm{C}$ to ${ }^{12} \mathrm{C}$.

Results of all these analyses are presented in Tables 3 through 8 . 


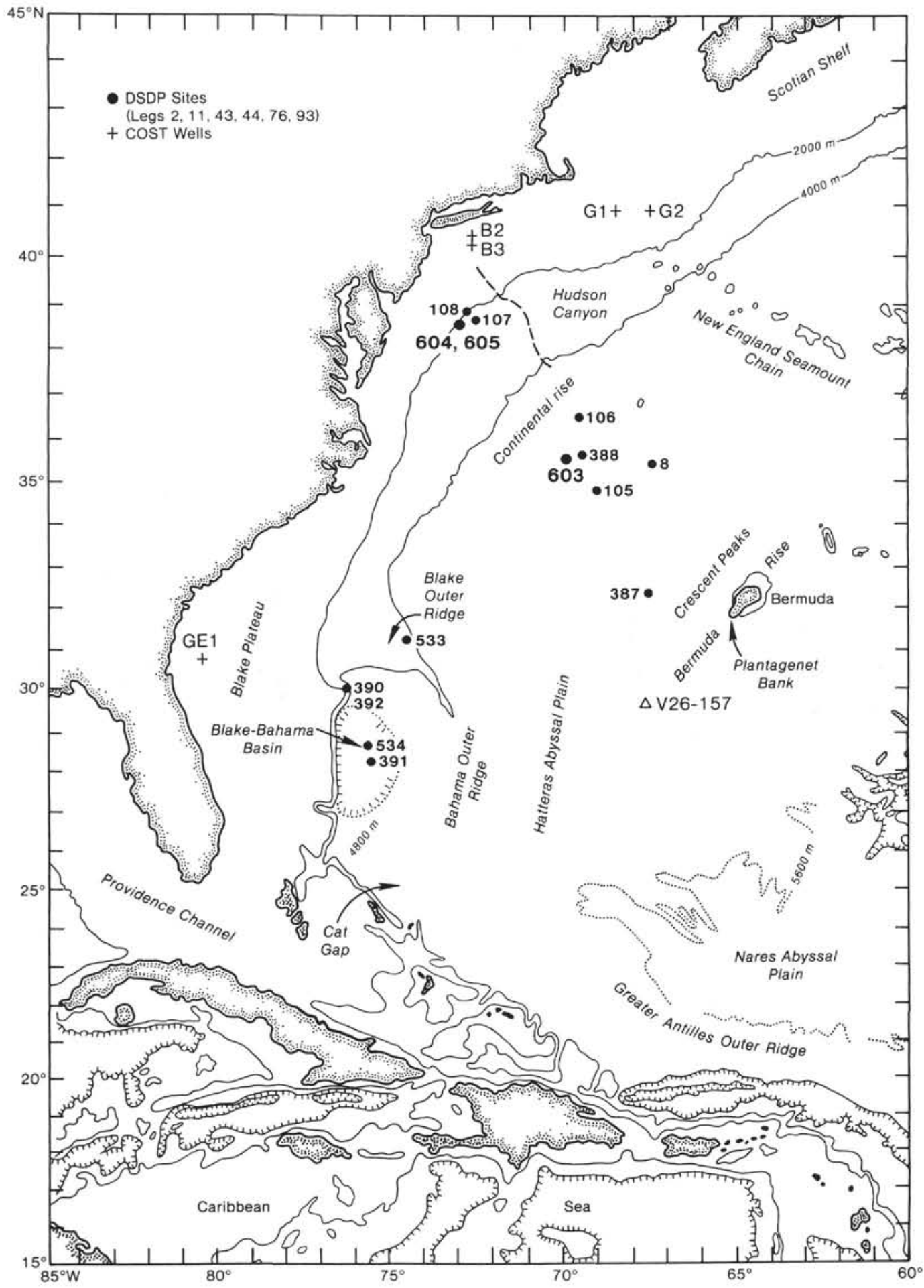

Figure 1. Map showing physiographic features of the North American Basin and locations of DSDP sites, Continental Offshore Stratigraphic Test (COST) wells, and Lamont-Doherty Geological Observatory core V26-157. Bathymetry after Uchupi, 1971.

\section{RESULTS AND INTERPRETATION}

\section{Lithologic Unit V-Neocomian Carbonates}

Interbeds of laminated dark olive to black marlstone and laminated to bioturbated white to light gray limestone of Tithonian through Neocomian age have been recovered at Sites 101, 105, 367, 387, 391, 534, and 603
(Fig. 1) in the North Atlantic, and at Sites 535 and 540 in the Gulf of Mexico (Buffler, Schlager, et al., 1984). This unit has been called the Blake-Bahama Formation by Jansa et al. (1979), and apparently is equivalent to the upper Tithonian to Aptian Maiolica (or Biancone) Formation of Garrison (1967), which is exposed in the Tethyan regions of the Mediterranean (Bernoulli, 1972; 

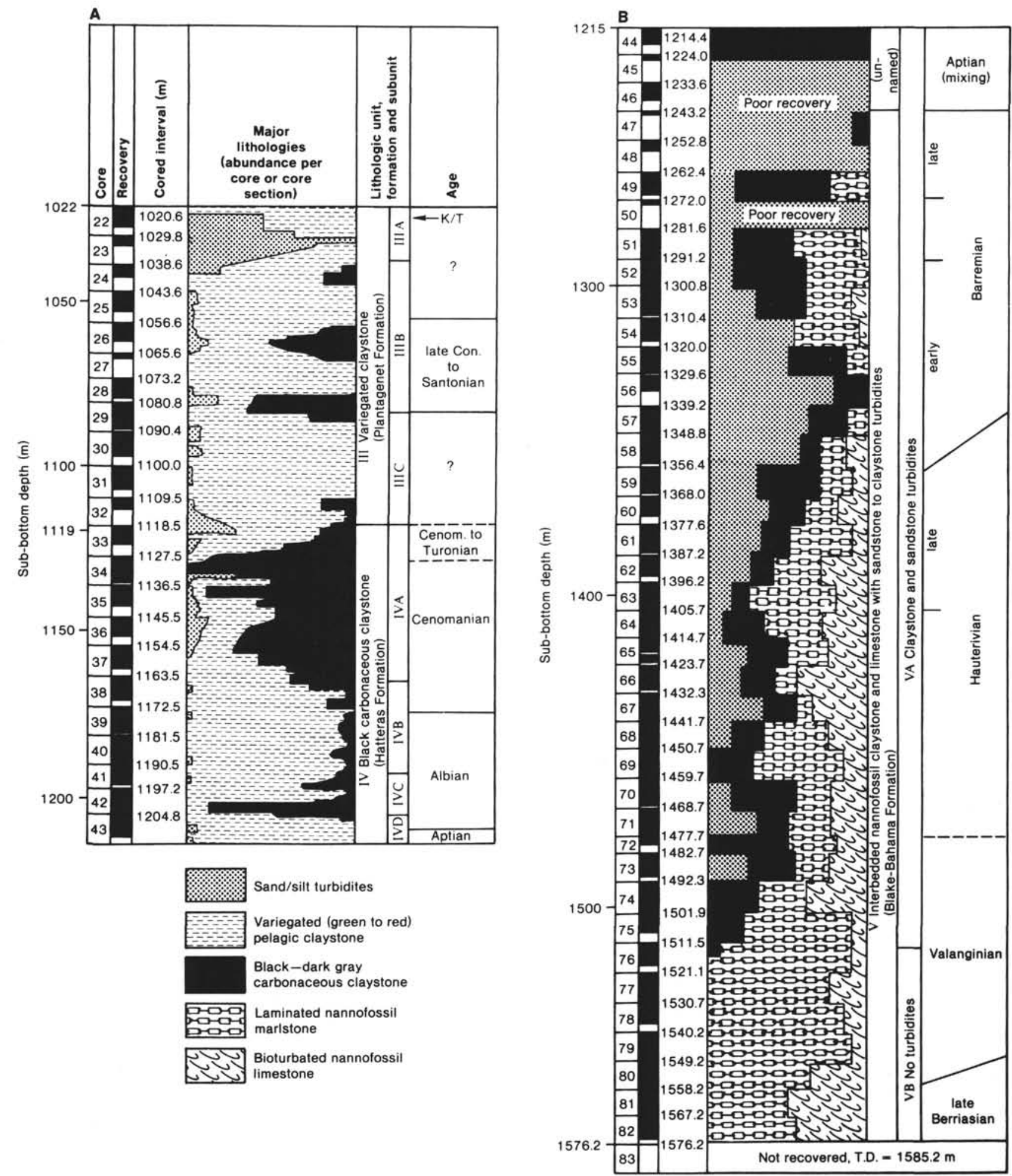

Figure 2. Lithology and age of strata recovered in Hole 603B.

Jansa et al., 1979), and to thick limestone sequences of the Vocontian Trough in France (Cotillon, 1984; Cotillon and Rio, 1984). This lithologic unit marks the widespread deposition of biogenic carbonate over much of the North Atlantic and Tethyan seafloor during a time of overall low sea level and a deep CCD (Tucholke and Vogt, 1979; Thierstein, 1979; Arthur and Dean, 1986). An abrupt rise of the CCD in the Barremian-Aptian marked the end of major pelagic deposition in the deep sea during the Cretaceous, and resulted in widespread 
Table 1. Locations and descriptions of analyzed shipboard samples from Hole 603B.

\begin{tabular}{|c|c|c|}
\hline $\begin{array}{l}\text { Core-Section, } \\
\text { interval }(\mathrm{cm})\end{array}$ & $\begin{array}{l}\text { Sub-bottom } \\
\text { depth } \\
\text { (m) }\end{array}$ & Description \\
\hline
\end{tabular}

Unit II: Radiolarian claystone (Eocene)

\begin{tabular}{|c|c|c|}
\hline $\begin{array}{l}15-3,128-131 \\
\text { Duplicate sample }\end{array}$ & 961.10 & Brown silty claystone \\
\hline $15-4,87-90$ & 962.10 & Green radiolarian claystone \\
\hline $15-5,87-90$ & 963.68 & Red radiolarian silty claystone \\
\hline $16-2,20-23$ & 968.12 & Dark gray radiolarian claystone \\
\hline
\end{tabular}

Unit III: Variegated claystone (Coniacian to Santonian)

\begin{tabular}{|c|c|c|}
\hline $\begin{array}{l}28-1,25-28 \\
\text { Duplicate sample }\end{array}$ & 1073.47 & Dark green claystone \\
\hline $\begin{array}{l}28-3,67-70 \\
\text { Duplicate sample }\end{array}$ & 1076.89 & Dark green claystone \\
\hline $\begin{array}{l}28-3,129-132 \\
\text { Duplicate sample }\end{array}$ & 1077.51 & Red claystone \\
\hline $28, \mathrm{CC}(5-8)$ & 1078.97 & Black claystone \\
\hline $\begin{array}{l}29-1,142-144 \\
\text { Duplicate sample }\end{array}$ & 1082.23 & Dark greenish gray claystone \\
\hline $29-4,103-105$ & 1086.34 & Variegatred red and green claystone \\
\hline $29-4,105-107$ & 1086.36 & Bright red claystone \\
\hline $32-1,45-47$ & 1109.96 & Red silty claystone \\
\hline $32-1,59-61$ & 1110.10 & Green silty claystone \\
\hline $32-1,61-63$ & 1110.12 & Black silty claystone \\
\hline $32-1,76-78$ & 1110.27 & Green silty claystone \\
\hline $32-1,115-117$ & 1110.66 & Red silty claystone \\
\hline
\end{tabular}

Unit IV: Black carbonaceous claystone (Aptian to Turonian)

\begin{tabular}{|c|c|c|}
\hline $34-2,35-40$ & 1129.38 & Black shale with pyrite nodule \\
\hline $36-1,115-116$ & 1146.66 & Dark greenish gray claystone \\
\hline $36-1,118-119$ & 1146.69 & Black shale \\
\hline $36-1,121-122$ & 1146.72 & Green shale \\
\hline $38-1,50-52$ & 1164.01 & Green shale \\
\hline $38-2,52-54$ & 1165.53 & Green shale \\
\hline $38-3,50-52$ & 1167.01 & Green shale \\
\hline $38-4,50-52$ & 1168.51 & Red claystone \\
\hline $38-5,52-54$ & 1170.03 & Green shale \\
\hline $43-2,30-32$ & 1206.61 & Red claystone \\
\hline \multicolumn{3}{|c|}{ Duplicate sample } \\
\hline $43-2,54-56$ & 1206.85 & Red claystone \\
\hline $43-2,111-114$ & 1207.42 & Red claystone \\
\hline $43-3,135-137$ & 1209.16 & Green claystone \\
\hline $43-4,15-18$ & 1209.43 & Cross-laminated green claystone \\
\hline $43-6,25-27$ & 1212.56 & Green shale \\
\hline
\end{tabular}

Unit V: Nannofossil limestone, marlstone, and claystone (Neocomian)

\begin{tabular}{lll}
$44-3,53-55$ & 1217.94 & Black shale \\
$53-5,28-30$ & 1307.09 & Homogeneous dark gray claystone \\
$53-5,32-34$ & 1307.13 & Homogeneous dark gray claystone \\
$57-1,80-83$ & 1340.02 & Laminated light brown-gray limestone \\
$57-1,86-88$ & 1340.07 & Homogeneous dark gray claystone \\
$57-1,93-95$ & 1340.14 & Laminated light brown-gray limestone \\
$58-4,102-104$ & 1354.33 & Homogeneous dark gray claystone \\
$58-4,104-106$ & 1354.35 & Bioturbated light gray limestone \\
$58-4,106-108$ & 1354.37 & Homogeneous dark gray marlstone \\
$63-5,128-130$ & 1403.49 & Homogeneous dark gray claystone \\
$63-5,132-134$ & 1403.53 & Laminated light brown-gray marlstone \\
$64-5,43-45$ & 1412.14 & Bioturbated light gray limestone \\
$64-5,46-48$ & 1412.17 & Homogeneous dark gray claystone \\
$64-5,48-50$ & 1412.19 & Laminated light gray limestone \\
$65-1,17-19$ & 1414.88 & Laminated dark green limestone \\
$65-4,100-102$ & 1420.21 & Bioturbated light gray limestone \\
$65-4,107-109$ & 1420.28 & Homogeneous dark gray claystone \\
$65-4,113-115$ & 1420.34 & Bioturbated light gray limestone \\
$66-3,25-27$ & 1426.96 & Bioturbated light gray limestone \\
$66-3,32-34$ & 1427.03 & Laminated light brown-gray limestone \\
$66-3,35-37$ & 1427.05 & Homogeneous dark gray claystone \\
$66-3,44-45$ & 1427.15 & Laminated light brown-gray limstone \\
$66-3,59-61$ & 1427.30 & Bioturbated light gray limestone \\
$66-3,126-128$ & 1438.47 & Black shale associated with pyrite nodule \\
$75-2,34-36$ & 1503.75 & Bioturbated light gray limestone \\
$75-2,48-50$ & 1503.89 & Homogeneous black claystone \\
Duplicate sample & & \\
$75-2,61-63$ & 1504.02 & Homogeneous black claystone \\
$75-2,70-72$ & 1504.11 & Laminated light brown-gray limestone \\
$75-2,86-88$ & 1504.27 & Bioturbated light gray limestone \\
$75-2,99-101$ & 1504.40 & Laminated medium brown-gray marlstone \\
$75-2,114-116$ & 1504.55 & Black shale associated with pyrite nodule \\
\hline & &
\end{tabular}

Table 2. Locations and descriptions of analyzed postcruise samples from Hole 603B.

\begin{tabular}{|c|c|c|c|}
\hline $\begin{array}{l}\text { Core-Section, } \\
\text { interval }(\mathrm{cm})\end{array}$ & $\begin{array}{l}\text { Sub-bottom } \\
\text { depth } \\
\text { (m) }\end{array}$ & Color & Comments \\
\hline \multicolumn{4}{|c|}{ Albian-Cenomanian claystones } \\
\hline $35-1,23-25$ & 1136.74 & Gray & Bentonite? \\
\hline $35-1,30-32$ & 1136.82 & Black & \\
\hline $35-1,49-51$ & 1137.00 & Black & Laminated; associated with pyrite nodule \\
\hline $35-2,18-20$ & 1138.20 & Black & Faintly laminated \\
\hline $35-2,47-48$ & 1138.47 & Black/green & Associated with pyrite nodule at contact \\
\hline $35-2,128-130$ & 1139.29 & Green & \\
\hline $36-3,8-11$ & 1148.60 & Green & \\
\hline $36-3,13-16$ & 1148.65 & Green & \\
\hline $36-3,17-19$ & 1148.68 & Black/green & Black /green contact at $18 \mathrm{~cm}$ \\
\hline $36-3,21-23$ & 1148.72 & Black and green & Bioturbated \\
\hline $36-3,27-29$ & 1148.78 & Dark gray & \\
\hline $36-3,35-37$ & 1148.86 & Black & Fissile \\
\hline $36-3,49-50$ & 1148.99 & Black & Fissile \\
\hline $36-3,57-59$ & 1149.08 & Black & Fissile \\
\hline $36-3,70-72$ & 1149.21 & Black & Fissile \\
\hline $37-1,30-32$ & 1154.81 & Black & Associated with pyrite nodule \\
\hline $37-1,33-35$ & 1154.84 & Black & Laminated; just below pyrite nodule \\
\hline $37-5,104-106$ & 1161.54 & Green & Bioturbated \\
\hline $37-5,107-109$ & 1161.57 & Black & \\
\hline $37-5,111-113$ & 1161.61 & Black & At contact with green claystone \\
\hline $38-1,146-149$ & 1164.97 & Black & Finely laminated \\
\hline Duplicate sample & & & \\
\hline $38-2,8-10$ & 1165.09 & Green & Finely laminated \\
\hline Duplicate sample & & & \\
\hline $38-2,18-21$ & 1165.19 & Black? & Thick black \\
\hline $38-2,22-25$ & 1165.23 & Black & shale unit \\
\hline $38-2,25-28$ & 1165.27 & Green & \\
\hline \multicolumn{4}{|l|}{ Neocomian carbonates } \\
\hline $66-3,3-5$ & 1426.73 & White & Bioturbated limestone \\
\hline $66-3,40-41$ & 1427.10 & Brown-gray & Laminated limestone \\
\hline $66-3,51-53$ & 1427.21 & Light gray & Bioturbated limestone \\
\hline \multicolumn{4}{|c|}{ Duplicate sample } \\
\hline $66-3,68-70$ & 1427.38 & Black & Homogeneous claystone \\
\hline $69-2,133-136$ & 1453.53 & Black & Homogeneous claystone \\
\hline $69-2,143-146$ & 1453.63 & Black & Homogeneous claystone \\
\hline $69-3,7-9$ & 1453.77 & White & Bioturbated limestone \\
\hline $69-3,19-20$ & 1453.89 & White & Bioturbated limestone \\
\hline $69-3,27-29$ & 1453.97 & Light gray & Laminated to bioturbated limestone \\
\hline $69-3,42-43$ & 1454.12 & Medium gray & Laminated limestone \\
\hline $69-3,48-50$ & 1454.18 & Medium gray & Laminated limestone \\
\hline $69-3,57-59$ & 1454.27 & Light gray & Laminated to bioturbated limestone \\
\hline $69-3,66-68$ & 1454.37 & Light gray & Bioturbated limestone \\
\hline $69-3,71-72$ & 1454.41 & Light gray & Bioturbated limestone \\
\hline Duplicate sample & & & \\
\hline
\end{tabular}

deposition of noncalcareous black shales of the Hatteras Formation (Jansa et al., 1979) over much of the deep North Atlantic.

Much of the Blake-Bahama Formation consists of interbedded laminated and bioturbated marlstone and limestone; the laminated units commonly are OC-rich. At Site 367 in the eastern North Atlantic basin, the dark marlstones are finely laminated and contain up to $5.5 \%$ OC (Dean and Gardner, 1982) with relatively high hydrogen indices (about $400 \mathrm{mg} \mathrm{HC} / \mathrm{g} \mathrm{OC}$; Herbin and Deroo, 1982; Dean et al., 1986), probably indicating enhanced preservation of predominantly marine organic matter under periodic anoxic conditions. In the western North Atlantic basin, although many of the limestone and marlstone beds are laminated, the darkest beds are not. The laminae in many of the limestone and marlstone beds, however, typically are thick and not so distinct, and it is not clear whether they indicate deposition under anoxic bottom water, as commonly has been assumed. The origin of the laminated Neocomian carbonates with high $\mathrm{OC}$ contents and accumulation rates (e.g., Arthur and Dean, 1986) remains an important question. Of equal importance is whether the change from limestone deposition during the Neocomian to black-shale deposition of the Hatteras Formation (Aptian to Turonian) was due simply to a shoaling of the CCD (e.g., Tu- 
Table 3. Inorganic and organic geochemical analyses of shipboard samples from Hole 603B.

\begin{tabular}{|c|c|c|c|c|c|c|c|c|c|c|c|c|c|c|c|c|}
\hline $\begin{array}{l}\text { Core-Section } \\
\text { interval }(\mathrm{cm})\end{array}$ & $\begin{array}{l}\mathrm{SiO}_{2} \\
(\%)\end{array}$ & $\begin{array}{c}\mathrm{Al}_{2} \mathrm{O}_{3} \\
(\%){ }_{0}\end{array}$ & $\begin{array}{c}\mathrm{Fe}_{2} \mathrm{O}_{3} \\
\left.(\%){ }_{0}\right)\end{array}$ & $\begin{array}{l}\mathrm{MgO} \\
(\%)\end{array}$ & $\begin{array}{l}\mathrm{CaO} \\
(\%)\end{array}$ & $\begin{array}{c}\mathrm{Na}_{2} \mathrm{O} \\
(\%)\end{array}$ & $\begin{array}{l}\mathrm{K}_{2} \mathrm{O} \\
(\%)\end{array}$ & $\begin{array}{l}\mathrm{TiO}_{2} \\
(\%)\end{array}$ & $\begin{array}{c}\mathrm{P}_{2} \mathrm{O}_{5} \\
(\%)\end{array}$ & $\begin{array}{c}\mathrm{MnO} \\
(\%)\end{array}$ & $\begin{array}{c}\mathrm{MnO} \\
(\%)\end{array}$ & $\begin{array}{l}\text { LOI900 } \\
(\%)\end{array}$ & $\begin{array}{c}\mathrm{Ba} \\
(\mathrm{ppm})\end{array}$ & $\begin{array}{c}\mathrm{Be} \\
(\mathrm{ppm})\end{array}$ & $\begin{array}{c}\mathrm{Co} \\
(\mathrm{ppm})\end{array}$ & $\underset{(\mathrm{ppm})}{\mathrm{Cr}}$ \\
\hline $15-3,128$ & 56.0 & 16.7 & 6.07 & 2.28 & 0.93 & 1.67 & 2.44 & 0.58 & 0.36 & 0.22 & 0.22 & 11.7 & 780 & 2 & 20 & 87 \\
\hline $15-3,128$ & 56.0 & 16.7 & 6.08 & 2.30 & 0.93 & 1.71 & 2.43 & 0.58 & 0.34 & 0.23 & 0.21 & 11.8 & 730 & 2 & 21 & 85 \\
\hline $15-4,87$ & 71.7 & 9.2 & 2.54 & 1.79 & 0.55 & 1.36 & 1.44 & 0.32 & 0.18 & 0.59 & 0.59 & 8.7 & 330 & $<2$ & 150 & 58 \\
\hline $15-5,87$ & 70.2 & 9.9 & 3.51 & 1.89 & 0.50 & 1.29 & 1.35 & 0.32 & 0.12 & 0.52 & 0.48 & 9.1 & 240 & $<2$ & 18 & 68 \\
\hline $16-2,20$ & 69.9 & 10.0 & 3.34 & 1.54 & 0.45 & 1.11 & 1.40 & 0.35 & 0.15 & 1.67 & 1.55 & 8.9 & 400 & $<2$ & 34 & 89 \\
\hline $28-1,25$ & 54.1 & 20.4 & 6.00 & 1.88 & 0.35 & 1.20 & 2.39 & 0.88 & 0.09 & 0.03 & 0.04 & 11.5 & 300 & 2 & 670 & 130 \\
\hline $28-1,25$ & 53.7 & 20.2 & 5.96 & 1.90 & 0.36 & 1.19 & 2.37 & 0.87 & 0.09 & 0.03 & 0.04 & 12.4 & 300 & 2 & 660 & 140 \\
\hline $28-3,67$ & 55.0 & 20.2 & 6.21 & 1.85 & 0.42 & 1.14 & 2.46 & 0.90 & 0.14 & 0.14 & 0.14 & 10.9 & 310 & 2 & 14 & 130 \\
\hline $28-3,67$ & 54.4 & 20.1 & 6.12 & 1.85 & 0.42 & 1.15 & 2.44 & 0.88 & 0.13 & 0.15 & 0.14 & 11.2 & 310 & 2 & 14 & 130 \\
\hline $28-3,129$ & 52.1 & 19.2 & 8.35 & 1.88 & 0.52 & 1.18 & 2.42 & 0.83 & 0.19 & 0.93 & 0.80 & 11.5 & 300 & 2 & 12 & 120 \\
\hline $28-3,129$ & 51.6 & 19.1 & 8.28 & 1.83 & 0.52 & 1.21 & 2.41 & 0.82 & 0.18 & 1.03 & 0.92 & 12.3 & 290 & 2 & 13 & 130 \\
\hline $28-8,5$ & 59.3 & 17.0 & 4.23 & 1.42 & 0.32 & 0.98 & 2.47 & 0.96 & 0.08 & $<0.02$ & 0.02 & 12.0 & 330 & 3 & 29 & 110 \\
\hline $29-1,142$ & 55.6 & 20.9 & 4.55 & 1.67 & 0.32 & 0.96 & 2.58 & 0.96 & 0.08 & $<0.02$ & 0.02 & 11.2 & 350 & 3 & 35 & 140 \\
\hline $29-1,142$ & 55.1 & 20.7 & 4.61 & 1.62 & 0.32 & 0.97 & 2.56 & 0.95 & 0.08 & $<0.02$ & 0.02 & 11.7 & 340 & 3 & 34 & 130 \\
\hline $29-4,103$ & 54.3 & 21.6 & 4.96 & 1.59 & 0.38 & 1.04 & 2.84 & 0.95 & 0.15 & 0.68 & 0.83 & 10.3 & 330 & 3 & 55 & 120 \\
\hline $29-4,105$ & 52.3 & 20.6 & 8.30 & 1.55 & 0.39 & 1.25 & 2.79 & 0.91 & 0.17 & 0.64 & 0.59 & 10.3 & 330 & 3 & 25 & 120 \\
\hline $32-1,45$ & 54.7 & 20.5 & 7.26 & 1.61 & 0.34 & 1.22 & 3.02 & 0.88 & 0.12 & 0.06 & 0.06 & 9.8 & 380 & 2 & 34 & 120 \\
\hline $32-1,59$ & 54.3 & 20.8 & 5.82 & 1.91 & 0.33 & 1.21 & 3.00 & 0.89 & 0.10 & 0.04 & 0.04 & 10.7 & 390 & 3 & 590 & 130 \\
\hline $32-1,61$ & 52.0 & 19.8 & 5.68 & 1.69 & 0.31 & 1.17 & 2.85 & 0.89 & 0.10 & 0.03 & 0.03 & 13.9 & 380 & 4 & 160 & 220 \\
\hline $32-1,76$ & 54.4 & 21.8 & 5.41 & 1.61 & 0.29 & 1.05 & 2.87 & 0.92 & 0.08 & 0.02 & 0.03 & 10.4 & 380 & 3 & 610 & 130 \\
\hline $32-1,115$ & 53.4 & 20.1 & 8.10 & 1.67 & 0.36 & 1.06 & 2.96 & 0.85 & 0.12 & 0.04 & 0.04 & 10.6 & 380 & 3 & 11 & 120 \\
\hline $34-2,35$ & 62.0 & 8.4 & 5.93 & 0.98 & 0.34 & 1.50 & 1.65 & 0.37 & 0.08 & $<0.02$ & 0.02 & 16.7 & 1,000 & $<2$ & 21 & 130 \\
\hline $36-1,115$ & 58.3 & 17.4 & 5.86 & 2.12 & 0.47 & 1.31 & 2.61 & 0.82 & 0.14 & $<0.02$ & 0.02 & 9.6 & 450 & 3 & 18 & 120 \\
\hline $36-1,118$ & 55.2 & 19.7 & 5.50 & 2.06 & 0.44 & 1.25 & 2.33 & 0.88 & 0.10 & $<0.02$ & 0.02 & 12.0 & 330 & 3 & 34 & 130 \\
\hline $36-1,121$ & 59.1 & 17.0 & 5.76 & 2.08 & 0.47 & 1.26 & 2.44 & 0.81 & 0.13 & $<0.02$ & 0.02 & 9.6 & 370 & 2 & 19 & 120 \\
\hline $38-1,50$ & 58.5 & 17.2 & 5.97 & 2.19 & 0.53 & 1.43 & 2.42 & 0.85 & 0.13 & 0.02 & 0.03 & 9.7 & 390 & 3 & 19 & 100 \\
\hline $38-2,52$ & 59.5 & 17.4 & 5.18 & 1.93 & 0.47 & 1.38 & 2.37 & 0.87 & 0.11 & $<0.02$ & 0.02 & 9.6 & 400 & 3 & 19 & 110 \\
\hline $38-3,50$ & 59.3 & 16.8 & 6.53 & 1.91 & 0.55 & 1.41 & 2.25 & 0.83 & 0.13 & $<0.02$ & 0.02 & 9.4 & 370 & 2 & 21 & 120 \\
\hline $38-4,50$ & 61.7 & 14.8 & 7.54 & 1.75 & 0.50 & 1.42 & 2.41 & 0.84 & 0.12 & 0.13 & 0.13 & 3.0 & 370 & 2 & 13 & 92 \\
\hline $38-5,52$ & 54.9 & 19.1 & 7.22 & 1.98 & 0.51 & 1.28 & 2.31 & 0.78 & 0.09 & $<0.02$ & 0.02 & 11.1 & 360 & 3 & 22 & 130 \\
\hline $43-2,30$ & 58.6 & 15.5 & 9.45 & 1.88 & 0.53 & 1.55 & 2.89 & 0.80 & 0.20 & 0.04 & 0.05 & 7.6 & 380 & 2 & 16 & 87 \\
\hline $43-2,30$ & 58.3 & 15.5 & 9.46 & 1.93 & 0.55 & 1.57 & 2.88 & 0.80 & 0.20 & 0.04 & 0.05 & 3.1 & 370 & 2 & 16 & 91 \\
\hline $43-2,54$ & 57.6 & 15.4 & 9.62 & 1.96 & 0.52 & 1.56 & 2.96 & 0.80 & 0.18 & 0.04 & 0.05 & 8.4 & 370 & 2 & 15 & 98 \\
\hline $43-2,111$ & 59.4 & 14.7 & 9.07 & 1.94 & 0.47 & 1.59 & 3.08 & 0.81 & 0.15 & 0.03 & 0.03 & 7.4 & 370 & 2 & 14 & 93 \\
\hline $43-3,135$ & 58.9 & 17.3 & 5.66 & 1.95 & 0.42 & 1.41 & 2.92 & 1.13 & 0.11 & 0.03 & 0.04 & 8.6 & 350 & 2 & 23 & 99 \\
\hline $43-4,15$ & 59.9 & 17.9 & 4.50 & 1.80 & 0.36 & 1.32 & 3.12 & 1.48 & 0.10 & 0.02 & 0.03 & 3.0 & 410 & 2 & 16 & 100 \\
\hline $43-6,25$ & 56.2 & 17.9 & 7,08 & 2.20 & 0.47 & 1.27 & 3.19 & 0.96 & 0.13 & 0.02 & 0.03 & 9.6 & 350 & 3 & 130 & 130 \\
\hline $44-3,53$ & 50.3 & 20.2 & 6.07 & 2.10 & 1.16 & 1.01 & 3.26 & 1.00 & 0.11 & 0.03 & 0.03 & 14.0 & 340 & 3 & 21 & 130 \\
\hline $53-5,28$ & 44.4 & 14.4 & 5.19 & 2.00 & 10.50 & 1.09 & 2.24 & 0.72 & 0.09 & 0.06 & 0.07 & 16.4 & 290 & $<2$ & 19 & 110 \\
\hline $53-5,32$ & 47.5 & 15.3 & 5.42 & 2.54 & 7.64 & 1.35 & 2.60 & 0.80 & 0.08 & $<0.02$ & 0.02 & 15.4 & 350 & 2 & 21 & 120 \\
\hline $57-1,80$ & 8.5 & 2.9 & 2.46 & 1.02 & 44.20 & 0.37 & 0.29 & 0.08 & 0.09 & 0.12 & 0.14 & 38.0 & 77 & $<2$ & 13 & 34 \\
\hline $57-1,86$ & 42.6 & 15.8 & 6.13 & 2.68 & 9.89 & 1.15 & 2.91 & 0.78 & 0.09 & 0.02 & 0.09 & 16.5 & 150 & $<2$ & 19 & 53 \\
\hline $57-1,93$ & 9.8 & 3.6 & 2.70 & 1.08 & 42.50 & 0.45 & 0.32 & 0.11 & 0.07 & 0.08 & 0.10 & 36.6 & 95 & $<2$ & 13 & 44 \\
\hline $58-4,102$ & 40.2 & 16.0 & 4.96 & 2.16 & 12.80 & 0.88 & 2.58 & 0.68 & 0.07 & $<0.02$ & 0.03 & 18.1 & 260 & $<2$ & 27 & 84 \\
\hline $58-4,104$ & 12.4 & 4.5 & 1.85 & 1.10 & 41.90 & 0.52 & 0.53 & 0.12 & 0.08 & 0.09 & 0.06 & 36.0 & 260 & $<2$ & 35 & 79 \\
\hline $58-4,106$ & 35.0 & 14.2 & 4.11 & 2.04 & 18.20 & 0.79 & 2.15 & 0.56 & 0.08 & 0.02 & 0.04 & 22.2 & 230 & $<2$ & 14 & 93 \\
\hline $63-5,128$ & 44.8 & 16.8 & 5.47 & 2.33 & 7.93 & 1.01 & 2.49 & 0.70 & 0.08 & 0.03 & 0.06 & 16.1 & 250 & $<2$ & 35 & 78 \\
\hline $63-5,132$ & 24.4 & 7.0 & 4.57 & 1.41 & 29.60 & 0.77 & 1.10 & 0.32 & 0.11 & 0.22 & 0.22 & 26.8 & 170 & $<2$ & 47 & 53 \\
\hline $64-5,43$ & 8.3 & 2.6 & 1.25 & 0.93 & 47.30 & 0.26 & 0.18 & 0.07 & 0.06 & 0.27 & 0.28 & 38.9 & 65 & $<2$ & 5 & 18 \\
\hline $64-5,46$ & 43.8 & 15.4 & 5.14 & 2.42 & 10.40 & 1.06 & 2.57 & 0.65 & 0.09 & $<0.02$ & 0.17 & 17.5 & 100 & $<2$ & 14 & 35 \\
\hline $64-5,48$ & 8.8 & 2.8 & 1.45 & 0.92 & 46.40 & 0.31 & 0.25 & 0.08 & 0.08 & 0.28 & 0.28 & 38.4 & 68 & $<2$ & 10 & 18 \\
\hline $65-1,17$ & 15.6 & 5.0 & 4.15 & 1.35 & 34.20 & 0.58 & 0.77 & 0.22 & 0.10 & 0.06 & 0.08 & 32.8 & 130 & $<2$ & 27 & 67 \\
\hline $65-4,100$ & 10.7 & 3.6 & 1.49 & 1.18 & 44.20 & 0.35 & 0.34 & 0.09 & 0.09 & 0.18 & 0.03 & 37.3 & 290 & $<2$ & 24 & 90 \\
\hline $65-4,107$ & 46.4 & 18.6 & 5.02 & 2.38 & 6.26 & 1.04 & 2.55 & 0.72 & 0.08 & $<0.02$ & 0.02 & 15.5 & 290 & 2 & 28 & 110 \\
\hline $65-4,113$ & 9.1 & 3.0 & 1.55 & 1.04 & 45.90 & 0.30 & 0.24 & 0.07 & 0.09 & 0.18 & 0.23 & 37.9 & 85 & $<2$ & 8 & 26 \\
\hline $66-3,25$ & 5.2 & 1.6 & 1.11 & 0.67 & 50.60 & 0.16 & 0.09 & 0.03 & 0.07 & 0.28 & 0.30 & 40.6 & 44 & $<2$ & 3 & 25 \\
\hline $66-3,32$ & 15.2 & 4.6 & 2.13 & 1.08 & 40.40 & 0.43 & 0.65 & 0.15 & 0.17 & 0.15 & 0.04 & 34.4 & 290 & 2 & 33 & 98 \\
\hline $66-3,35$ & 41.1 & 11.9 & 6.28 & 2.13 & 13.90 & 1.21 & 2.17 & 0.62 & 0.11 & 0.03 & 0.05 & 17.5 & 390 & $<2$ & 51 & 87 \\
\hline $66-3,44$ & 4.4 & 1.5 & 1.39 & 0.64 & 50.10 & 0.18 & 0.06 & 0.02 & 0.08 & 0.30 & 0.30 & 40.6 & 71 & $<2$ & 11 & 17 \\
\hline $66-3,59$ & 13.4 & 4.4 & 1.87 & 1.00 & 42.00 & 0.36 & 0.50 & 0.13 & 0.10 & 0.19 & 0.21 & 35.3 & 93 & $<2$ & 8 & 27 \\
\hline $67-4,126$ & 42.4 & 14.0 & 7.34 & 2.18 & 10.40 & 1.11 & 2.32 & 0.63 & 0.07 & $<0.02$ & 0.04 & 16.9 & 350 & 2 & 26 & 110 \\
\hline $75-2,34$ & 18.0 & 4.1 & 1.96 & 0.96 & 39.60 & 0.36 & 0.52 & 0.13 & 0.09 & 0.22 & 0.22 & 33.3 & 120 & $<2$ & 42 & 35 \\
\hline $75-2,48$ & 41.2 & 13.3 & 5.09 & 2.32 & 13.80 & 1.0 & 2.10 & 0.57 & 0.09 & 0.04 & 0.19 & 19.2 & 75 & $<2$ & 5 & 26 \\
\hline $75-2,48$ & 41.2 & 13.1 & 5.07 & 2.28 & 13.70 & 1.09 & 2.08 & 0.56 & 0.08 & 0.04 & 0.19 & 19.5 & 110 & $<2$ & 12 & 30 \\
\hline $75-2,61$ & 40.9 & 12.9 & 5.07 & 2.27 & 14.50 & 1.08 & 2.07 & 0.55 & 0.09 & 0.05 & 0.06 & 19.1 & 250 & $<2$ & 50 & 81 \\
\hline $75-2,70$ & 18.0 & 5.0 & 2.76 & 1.14 & 37.10 & 0.46 & 0.66 & 0.17 & 0.09 & 0.20 & 0.12 & 32.3 & 91 & $<2$ & 7 & 29 \\
\hline $75-2,86$ & 18.0 & 4.8 & 1.84 & 1.01 & 39.00 & 0.40 & 0.56 & 0.16 & 0.07 & 0.17 & 0.32 & 33.4 & 48 & $<2$ & 12 & 15 \\
\hline $75-2,99$ & 23.0 & 6.8 & 3.16 & 1.34 & 31.60 & 0.65 & 0.98 & 0.25 & 0.10 & 0.07 & 0.03 & 30.3 & 290 & $<2$ & 23 & 94 \\
\hline $75-2,114$ & 44.6 & 16.6 & 5.95 & 2.26 & 8.12 & 0.98 & 2.23 & 0.67 & 0.09 & 0.02 & 0.04 & 16.7 & 270 & $<2$ & 24 & 91 \\
\hline
\end{tabular}

Note: $\mathrm{LOI}=$ loss on ignition; $\mathrm{CaCO}_{3}-\mathrm{Ca}=$ concentration of $\mathrm{CaCO}_{3}$ calculated from total $\mathrm{Ca}$ concentration; $\mathrm{CaCO}_{3}-\mathrm{MA}=\mathrm{CaCO}$ concentration determined at Univ. of Rhode Island; OC-MA = organic carbon concentration determined at Univ. of Rhode Island; OC-RE = organic carbon concentration determined by Rock-Eval pyrolysis; Prod-I = production index (see "Methods"); $\mathrm{T}_{\max }=$ temperature of maximum yield of pyrolitic hydrocarbons. Dashes indicate no analysis. Samples with the same core-section, interval designation are analytical duplicates, as indicated in Table 1. 
Table 3 (continued).

\begin{tabular}{|c|c|c|c|c|c|c|c|c|c|c|c|c|c|c|c|c|}
\hline$\underset{(\mathrm{ppm})}{\mathrm{Cu}}$ & $\underset{(\mathrm{ppm})}{\mathrm{La}}$ & $\begin{array}{c}\text { Mo } \\
\text { (ppm) }\end{array}$ & $\begin{array}{c}\mathrm{Nb} \\
(\mathrm{ppm})\end{array}$ & $\begin{array}{c}\mathrm{Ni} \\
(\mathrm{ppm})\end{array}$ & $\begin{array}{c}\mathrm{Pb} \\
(\mathrm{ppm})\end{array}$ & $\underset{(\mathrm{ppm})}{\mathrm{Sc}}$ & $\begin{array}{c}\mathrm{Sr} \\
(\mathrm{ppm})\end{array}$ & $\begin{array}{c}\mathrm{V} \\
(\mathrm{ppm})\end{array}$ & $\underset{(\mathrm{ppm})}{\mathrm{Y}}$ & $\underset{(\mathrm{ppm})}{\mathrm{Zn}}$ & $\underset{(\mathrm{ppm})}{\mathrm{Ce}}$ & $\begin{array}{c}\mathrm{Ga} \\
(\mathrm{ppm})\end{array}$ & $\underset{(\mathrm{ppm})}{\mathrm{Li}}$ & $\begin{array}{c}\text { Th } \\
\text { (ppm) }\end{array}$ & $\begin{array}{c}\mathrm{Yb} \\
(\mathrm{ppm})\end{array}$ & $\underset{(\mathrm{ppm})}{\mathrm{Nd}}$ \\
\hline 160 & 51 & $<4$ & $<8$ & 61 & 15 & 19 & 260 & 81 & 43 & 150 & 110 & 22 & 89 & 21 & 4 & 56 \\
\hline 160 & 49 & $<4$ & $<8$ & 60 & 15 & 19 & 260 & 79 & 40 & 140 & 110 & 20 & 86 & 21 & 4 & 55 \\
\hline 81 & 29 & 10 & $<8$ & 210 & 36 & 11 & 140 & 63 & 22 & 54 & 52 & 14 & 45 & 17 & 2 & 30 \\
\hline 83 & 22 & $<4$ & $<8$ & 52 & $<8$ & 12 & 120 & 56 & 13 & 110 & 38 & 14 & 61 & 12 & $<2$ & 22 \\
\hline 100 & 28 & 8 & $<8$ & 61 & $<8$ & 12 & 130 & 68 & 20 & 75 & 53 & 17 & 54 & 13 & $<2$ & 29 \\
\hline 64 & 37 & $<4$ & 9 & 660 & 32 & 19 & 160 & 160 & 15 & 92 & 95 & 26 & 80 & 14 & 2 & 36 \\
\hline 63 & 37 & $<4$ & 8 & 650 & 33 & 19 & 160 & 160 & 14 & 89 & 93 & 27 & 79 & 16 & $<2$ & 34 \\
\hline 35 & 36 & $<4$ & $<8$ & 45 & 13 & 19 & 160 & 140 & 15 & 98 & 94 & 26 & 84 & 18 & 2 & 38 \\
\hline 35 & 37 & $<4$ & $<8$ & 44 & 13 & 18 & 160 & 130 & 14 & 100 & 91 & 25 & 83 & 16 & $<2$ & 33 \\
\hline 39 & 35 & $<4$ & 10 & 41 & 23 & 18 & 160 & 130 & 18 & 95 & 92 & 28 & 81 & 13 & 2 & 28 \\
\hline 39 & 34 & $<4$ & $<8$ & 47 & 12 & 17 & 160 & 130 & 17 & 95 & 90 & 25 & 78 & 21 & 2 & 34 \\
\hline 34 & 32 & 10 & 8 & 74 & 20 & 15 & 120 & 120 & 14 & 180 & 72 & 25 & 75 & 17 & 2 & 33 \\
\hline 58 & 36 & $<4$ & 12 & 84 & 30 & 18 & 140 & 160 & 15 & 380 & 76 & 27 & 100 & 17 & 2 & 30 \\
\hline 56 & 36 & $<4$ & 12 & 81 & 29 & 18 & 140 & 160 & 15 & 370 & 79 & 27 & 96 & 19 & 2 & 36 \\
\hline 210 & 42 & $<4$ & 12 & 150 & 31 & 20 & 150 & 130 & 19 & 130 & 110 & 29 & 130 & 16 & 3 & 37 \\
\hline 33 & 42 & $<4$ & 11 & 67 & 14 & 20 & 150 & 160 & 21 & 110 & 110 & 27 & 120 & 21 & 3 & 42 \\
\hline 17 & 47 & $<4$ & 10 & 73 & 11 & 19 & 160 & 130 & 19 & 85 & 96 & 26 & 76 & 16 & 3 & 44 \\
\hline 250 & 43 & $<4$ & 9 & 360 & 39 & 21 & 170 & 270 & 16 & 100 & 81 & 30 & 74 & 16 & 2 & 36 \\
\hline 280 & 38 & 5 & 11 & 180 & 110 & 20 & 150 & 1,300 & 14 & 3,000 & 67 & 29 & 76 & 16 & 2 & 37 \\
\hline 32 & 49 & $<4$ & $<8$ & 810 & 21 & 20 & 160 & 150 & 14 & 78 & 100 & 30 & 81 & 16 & 2 & 44 \\
\hline 55 & 49 & $<4$ & 9 & 47 & 9 & 19 & 170 & 140 & 18 & 93 & 110 & 25 & 74 & 17 & 2 & 45 \\
\hline 120 & 18 & 11 & $<8$ & 200 & 15 & 9 & 350 & 640 & 13 & 280 & 25 & 10 & 21 & 9 & $<2$ & 17 \\
\hline 75 & 40 & $<4$ & $<8$ & 66 & 22 & 16 & 210 & 120 & 20 & 180 & 75 & 25 & 60 & 17 & 2 & 43 \\
\hline 68 & 40 & $<4$ & 8 & 110 & 17 & 16 & 180 & 120 & 16 & 89 & 79 & 23 & 77 & 17 & $<2$ & 40 \\
\hline 55 & 42 & $<4$ & 8 & 86 & 19 & 16 & 210 & 120 & 20 & 82 & 80 & 23 & 58 & 13 & 2 & 38 \\
\hline 130 & 43 & $<4$ & $<8$ & 59 & 25 & 17 & 230 & 110 & 24 & 100 & 83 & 27 & 57 & 16 & 2 & 46 \\
\hline 120 & 37 & $<4$ & $<8$ & 59 & 15 & 17 & 220 & 120 & 18 & 330 & 71 & 25 & 58 & 16 & 2 & 41 \\
\hline 180 & 39 & $<4$ & 9 & 66 & 13 & 17 & 240 & 130 & 20 & 70 & 76 & 22 & 44 & 15 & 3 & 39 \\
\hline 35 & 38 & $<4$ & 9 & 47 & 11 & 15 & 210 & 65 & 19 & 81 & 75 & 21 & 37 & 14 & 2 & 36 \\
\hline 42 & 36 & $<4$ & 10 & 71 & 11 & 18 & 240 & 110 & 15 & 110 & 71 & 25 & 60 & 15 & $<2$ & 35 \\
\hline 81 & 43 & $<4$ & 11 & 67 & 14 & 17 & 200 & 110 & 32 & 98 & 95 & 22 & 54 & 12 & 3 & 43 \\
\hline 63 & 43 & $<4$ & 10 & 69 & 15 & 17 & 200 & 110 & 32 & 98 & 98 & 21 & 55 & 13 & 3 & 46 \\
\hline 59 & 40 & $<4$ & $<8$ & 72 & 15 & 18 & 200 & 100 & 27 & 97 & 85 & 20 & 52 & 16 & 3 & 42 \\
\hline 49 & 37 & $<4$ & $<8$ & 58 & 12 & 17 & 190 & 130 & 21 & 94 & 81 & 22 & 51 & 17 & 2 & 40 \\
\hline 150 & 38 & $<4$ & 35 & 97 & 24 & 15 & 190 & 89 & 15 & 250 & 68 & 23 & 81 & 17 & 2 & 34 \\
\hline 110 & 39 & $<4$ & 33 & 70 & 12 & 15 & 180 & 120 & 13 & 350 & 76 & 24 & 89 & 16 & 2 & 40 \\
\hline 62 & 46 & $<4$ & 13 & 290 & 20 & 18 & 210 & 130 & 24 & 98 & 93 & 26 & 81 & 23 & 3 & 50 \\
\hline 74 & 42 & $<4$ & 13 & 66 & 15 & 17 & 170 & 160 & 17 & 130 & 71 & 24 & 140 & 15 & 2 & 39 \\
\hline 55 & 26 & $<4$ & $<8$ & 55 & 13 & 14 & 420 & 130 & 9 & 97 & 44 & 19 & 66 & 10 & $<2$ & 17 \\
\hline 55 & 25 & $<4$ & $<8$ & 52 & 15 & 16 & 400 & 150 & 8 & 99 & 38 & 21 & 68 & 11 & $<2$ & 21 \\
\hline 47 & 28 & $<4$ & $<8$ & 43 & 11 & 5 & 860 & 28 & 29 & 39 & 52 & $<8$ & 50 & $<8$ & 3 & 42 \\
\hline 71 & 25 & $<4$ & $<8$ & 48 & 12 & 8 & 710 & 54 & 15 & 83 & 54 & 10 & 27 & $<8$ & $<2$ & 36 \\
\hline 45 & 33 & $<4$ & $<8$ & 43 & 12 & 11 & 970 & 34 & 31 & 62 & 62 & $<8$ & 20 & $<8$ & 3 & 44 \\
\hline 46 & 24 & $<4$ & $<8$ & 64 & 17 & 12 & 420 & 100 & 7 & 110 & 35 & 21 & 99 & 8 & $<2$ & 25 \\
\hline 63 & 22 & $<4$ & $<8$ & 110 & 15 & 13 & 560 & 90 & 8 & 110 & 38 & 19 & 52 & 8 & $<2$ & 26 \\
\hline 51 & 24 & $<4$ & $<8$ & 41 & 20 & 11 & 560 & 110 & 9 & 88 & 34 & 20 & 98 & $<8$ & $<2$ & 25 \\
\hline 58 & 22 & $<4$ & $<8$ & 100 & 14 & 13 & 550 & 88 & 8 & 120 & 36 & 19 & 50 & $<8$ & $<2$ & 27 \\
\hline 77 & 23 & $<4$ & $<8$ & 160 & 16 & 6 & 630 & 54 & 13 & 190 & 42 & 11 & 63 & $<8$ & $<2$ & 33 \\
\hline 19 & 20 & $<4$ & $<8$ & 10 & $<8$ & $<4$ & 690 & 17 & 17 & 38 & 34 & $<8$ & 43 & $<8$ & $<2$ & 30 \\
\hline 82 & 22 & $<4$ & $<8$ & 32 & $<8$ & 5 & 630 & 41 & 16 & 73 & 40 & 10 & 20 & $<8$ & $<2$ & 35 \\
\hline 30 & 20 & $<4$ & $<8$ & 20 & $<8$ & $<4$ & 660 & 19 & 16 & 30 & 36 & $<8$ & 13 & $<8$ & $<2$ & 28 \\
\hline 48 & 16 & $<4$ & $<8$ & 69 & 10 & 4 & 710 & 88 & 10 & 84 & 32 & 10 & 51 & $<8$ & $<2$ & 23 \\
\hline 50 & 24 & $<4$ & $<8$ & 84 & 19 & 14 & 460 & 120 & 8 & 98 & 41 & 21 & 66 & 9 & $<2$ & 23 \\
\hline 46 & 28 & $<4$ & $<8$ & 72 & 17 & 15 & 360 & 120 & 8 & 96 & 45 & 24 & 100 & 15 & $<2$ & 27 \\
\hline 38 & 24 & $<4$ & $<8$ & 30 & 6 & 5 & 700 & 24 & 21 & 50 & 55 & $<8$ & 55 & $<8$ & 2 & 38 \\
\hline 12 & 12 & $<4$ & $<8$ & 12 & $<8$ & $<4$ & 490 & 10 & 10 & $<8$ & 19 & $<8$ & 30 & $<8$ & $<2$ & 23 \\
\hline 49 & 27 & $<4$ & $<8$ & 110 & 20 & 15 & 400 & 120 & 8 & 93 & 51 & 25 & 97 & 13 & $<2$ & 30 \\
\hline 56 & 19 & $<4$ & $<8$ & 100 & 20 & 10 & 470 & 100 & 8 & 240 & 32 & 19 & 46 & $<8$ & $<2$ & 24 \\
\hline 32 & 21 & $<4$ & $<8$ & 18 & $<8$ & $<4$ & 680 & 20 & 16 & 31 & 40 & $<8$ & 13 & $<8$ & $<2$ & 30 \\
\hline 41 & 25 & $<4$ & $<8$ & 20 & 11 & 5 & 590 & 29 & 19 & 130 & 48 & 8 & 24 & $<8$ & $<2$ & 35 \\
\hline 59 & 31 & $<4$ & $<8$ & 58 & 10 & 17 & 460 & 130 & 13 & 110 & 53 & 28 & 72 & 10 & $<2$ & 34 \\
\hline 68 & 26 & $<4$ & $<8$ & 110 & 11 & 6 & 730 & 36 & 19 & 100 & 57 & 10 & 33 & $<8$ & 2 & 41 \\
\hline 28 & 25 & $<4$ & $<8$ & 9 & $<8$ & 6 & 750 & 24 & 20 & 18 & 55 & $<8$ & 57 & $<8$ & 2 & 40 \\
\hline 44 & 26 & $<4$ & $<8$ & 31 & 9 & 5 & 690 & 35 & 20 & 49 & 54 & 9 & 21 & $<8$ & 2 & 35 \\
\hline 57 & 22 & $<4$ & $<8$ & 140 & 13 & 13 & 550 & 86 & 8 & 110 & 38 & 20 & 47 & $<8$ & $<2$ & 26 \\
\hline 42 & 21 & $<4$ & $<8$ & 15 & 8 & 7 & 730 & 39 & 17 & 33 & 38 & 10 & 63 & $<8$ & $<2$ & 31 \\
\hline 27 & 15 & $<4$ & $<8$ & 26 & $<8$ & $<4$ & 690 & 14 & 12 & 78 & 24 & $<8$ & 27 & $<8$ & $<2$ & 25 \\
\hline 53 & 24 & $<4$ & $<8$ & 62 & 17 & 12 & 440 & 110 & 7 & 97 & 32 & 22 & 76 & 9 & $<2$ & 24 \\
\hline 55 & 28 & $<4$ & $<8$ & 73 & 24 & 14 & 470 & 99 & 8 & 90 & 50 & 24 & 81 & 11 & $<2$ & 31 \\
\hline
\end{tabular}


W. E. DEAN, M. A. ARTHUR

Table 3 (continued),

\begin{tabular}{|c|c|c|c|c|c|c|c|c|c|c|c|c|}
\hline $\begin{array}{l}\text { Core-Section } \\
\text { interval }(\mathrm{cm})\end{array}$ & $\begin{array}{c}\mathrm{CaCO}_{3}-\mathrm{Ca} \\
(\%)\end{array}$ & $\begin{array}{c}\mathrm{CaCO}_{3}-\mathrm{MA} \\
(\%)\end{array}$ & $\begin{array}{c}\text { Total S } \\
(\%)\end{array}$ & $\begin{array}{c}\text { OC-MA } \\
(\%)\end{array}$ & $\begin{array}{c}\text { OC-RE } \\
(\%)\end{array}$ & $\begin{array}{c}\text { Total N } \\
(\%)\end{array}$ & $\mathrm{C} / \mathrm{N}$ & H-index & O-index & Prod-1 & $\mathrm{T}_{\max }$ & $\delta^{13} \mathrm{C}_{\text {org }}$ \\
\hline $15-3,128$ & 1.7 & 0.0 & 0.05 & 0.09 & - & 0.033 & 2.7 & - & - & - & - & - \\
\hline $15-3,128$ & 1.7 & 0.0 & 0.08 & 0.08 & - & 0.036 & 2.2 & - & - & - & - & - \\
\hline $15-4,87$ & 1.0 & 0.0 & 0.06 & 0.14 & - & 0.020 & 7.0 & - & - & - & - & - \\
\hline $15-5,87$ & 0.9 & 0.0 & 0.01 & 0.09 & - & 0.020 & 4.5 & - & - & - & - & - \\
\hline $16-2,20$ & 0.8 & 0.0 & 0.25 & 1.42 & - & 0.047 & 30.2 & - & - & - & - & - \\
\hline $28-1,25$ & 0.6 & 0.0 & 0.08 & 0.18 & 0.06 & 0.035 & 5.1 & 266 & 500 & 0.1 & 466 & -25.9 \\
\hline $28-1,25$ & 0.6 & 0.0 & 0.09 & 0.17 & - & 0.035 & 4.9 & - & - & - & - & - \\
\hline $28-3,67$ & 0.8 & 0.0 & 0.90 & 0.18 & - & 0.033 & 4.8 & - & - & - & - & - \\
\hline $28-3,67$ & 0.8 & 0.0 & 0.06 & 0.14 & - & 0.031 & 4.5 & - & - & - & - & - \\
\hline $28-3,129$ & 0.9 & 0.0 & 0.04 & 0.18 & - & 0.033 & 5.5 & - & - & - & - & - \\
\hline $28-3,129$ & 0.9 & 0.0 & 0.04 & 0.19 & - & 0.032 & 5.9 & - & - & - & - & - \\
\hline $28-8,5$ & 0.6 & 0.0 & 0.58 & 2.40 & 2.41 & 0.082 & 29.3 & 17 & 48 & 0.0 & 413 & -25.0 \\
\hline $29-1,142$ & 0.6 & 0.0 & 0.40 & 0.92 & 0.87 & 0.051 & 18.0 & 16 & 63 & 0.2 & 444 & -25.0 \\
\hline $29-1,142$ & 0.6 & 0.0 & 0.46 & 0.95 & - & 0.056 & 17.0 & - & - & - & - & - \\
\hline $29-4,103$ & 0.7 & 0.0 & 0.06 & 0.11 & - & 0.029 & 3.8 & - & - & - & - & - \\
\hline $29-4,105$ & 0.7 & 0.0 & 0.05 & 0.10 & - & 0.032 & 3.1 & - & - & - & - & - \\
\hline $32-1,45$ & 0.6 & 0.0 & 0.02 & 0.12 & - & 0.034 & 3.5 & - & - & - & - & - \\
\hline $32-1,59$ & 0.6 & 0.0 & 0.02 & 0.17 & 0.09 & 0.036 & 4.7 & 322 & 311 & 0.1 & 449 & -25.5 \\
\hline $32-1,61$ & 0.6 & 0.0 & 1.29 & 3.33 & 3.00 & 0.140 & 23.8 & 215 & 40 & 0.0 & 417 & -26.0 \\
\hline $32-1,76$ & 0.5 & 0.0 & 0.05 & 0.15 & 0.09 & 0.037 & 4.1 & 200 & 300 & 0.1 & 439 & -26.0 \\
\hline $32-1,115$ & 0.6 & 0.0 & 0.15 & 0.10 & - & 0.033 & 3.0 & - & - & - & - & - \\
\hline $34-2,35$ & 0.6 & 0.0 & 2.46 & 5.26 & 3.74 & 0.181 & 29.1 & 388 & 49 & 0.0 & 396 & -24.3 \\
\hline $36-1,115$ & 0.8 & 0.0 & 0.16 & 0.38 & 0.25 & 0.029 & 13.1 & 52 & 248 & 0.1 & 484 & -25.4 \\
\hline $36-1,118$ & 0.8 & 0.0 & 0.25 & 1.35 & 1.35 & 0.056 & 24.1 & 36 & 74 & 0.0 & 413 & -26.2 \\
\hline $36-1,121$ & 0.8 & 0.0 & 0.21 & 0.21 & 0.12 & 0.025 & 8.4 & 66 & 500 & 0.0 & 533 & -25.6 \\
\hline $38-1,50$ & 0.9 & 0.0 & 0.08 & 0.30 & - & 0.027 & 11.1 & - & - & - & - & - \\
\hline $38-2,52$ & 0.8 & 0.0 & 0.12 & 0.46 & 0.33 & 0.032 & 14.4 & 36 & 181 & 0.1 & 504 & -25.2 \\
\hline $38-3,50$ & 1.0 & 0.0 & 0.09 & 0.21 & - & 0.030 & 7.0 & - & - & - & - & - \\
\hline $38-4,50$ & 0.9 & 0.0 & 0.02 & 0.13 & - & 0.020 & 6.5 & - & - & - & - & - \\
\hline $38-5,52$ & 0.9 & 0.0 & 0.05 & 0.52 & 0.30 & 0.039 & 13.3 & 30 & 200 & 0.2 & 481 & -26.1 \\
\hline $43-2,30$ & 0.9 & 0.0 & 0.01 & 0.11 & - & 0.020 & 5.5 & - & - & - & - & - \\
\hline $43-2,30$ & 1.0 & 0.0 & 0.04 & 0.14 & - & 0.021 & 6.7 & - & - & - & - & - \\
\hline $43-2,54$ & 0.9 & 0.0 & 0.02 & 0.08 & - & 0.020 & 4.0 & - & - & - & - & - \\
\hline $43-2,111$ & 0.8 & 0.0 & 0.03 & 0.07 & - & 0.017 & 4.1 & - & - & - & - & - \\
\hline $43-3,135$ & 0.8 & 0.0 & 0.03 & 0.11 & - & 0.015 & 7.3 & - & - & - & - & - \\
\hline $43-4,15$ & 0.6 & 0.0 & 0.01 & 0.08 & - & 0.012 & 6.7 & - & - & - & - & - \\
\hline $43-6,25$ & 0.8 & 0.0 & 0.14 & 0.36 & 0.23 & 0.028 & 12.9 & 52 & 200 & 0.1 & 522 & -24.3 \\
\hline $44-3,53$ & 2.1 & 0.0 & 1.29 & 3.21 & 3.10 & 0.118 & 27.2 & 91 & 51 & 0.0 & 425 & -25.2 \\
\hline $53-5,28$ & 18.8 & 0.0 & 0.81 & 2.58 & 2.71 & 0.098 & 26.3 & 47 & 60 & 0.0 & 425 & -26.7 \\
\hline $53-5,32$ & 13.6 & 13.6 & 0.51 & 1.70 & 2.16 & 0.058 & 25.4 & 33 & 68 & 0.0 & 420 & -25.8 \\
\hline $57-1,80$ & 78.9 & 80.5 & 0.59 & 1.41 & 2.01 & 0.056 & 25.0 & 115 & 81 & 0.0 & 422 & -26.7 \\
\hline $57-1,86$ & 17.7 & 16.0 & 0.73 & 2.06 & 1.77 & 0.077 & 27.0 & 25 & 81 & 0.0 & 418 & -24.4 \\
\hline $57-1,93$ & 75.9 & 75.1 & 0.65 & 1.57 & 2.43 & 0.061 & 26.0 & 126 & 79 & 0.0 & 422 & -26.5 \\
\hline $58-4,102$ & 22.9 & 20.4 & 0.78 & 1.85 & - & 0.063 & 29.0 & - & - & - & - & - \\
\hline $58-4,104$ & 74.8 & 76.0 & 0.21 & 0.44 & - & 0.015 & 29.0 & - & - & - & - & - \\
\hline $58-4,106$ & 32.5 & 29.9 & 0.54 & 1.73 & - & 0.062 & 28.0 & - & - & - & - & - \\
\hline $63-5,128$ & 14.2 & 11.4 & 0.99 & 2.74 & 2.66 & 0.088 & 31.0 & 23 & 55 & 0.0 & 418 & -25.3 \\
\hline $63-5,132$ & 52.9 & 52.4 & 0.61 & 1.50 & 2.11 & 0.046 & 33.0 & 79 & 85 & 0.1 & 421 & -26.5 \\
\hline $64-5,43$ & 84.5 & 85.1 & 0.06 & 0.21 & 0.37 & 0.006 & 35.0 & 2 & 254 & 0.0 & - & -25.3 \\
\hline $64-5,46$ & 18.6 & 16.8 & 0.53 & 1.61 & 1.87 & 0.053 & 30.0 & 30 & 69 & 0.0 & 416 & -25.3 \\
\hline $64-5,48$ & 82.9 & 84.3 & 0.13 & 0.43 & 0.53 & 0.012 & 36.0 & 20 & 184 & 0.2 & 412 & -25.6 \\
\hline $65-1,17$ & 61.1 & 61.6 & 1.25 & 3.08 & 3.49 & 0.086 & 36.0 & 101 & 79 & 0.0 & 417 & -25.7 \\
\hline $65-4,100$ & 78.9 & 79.7 & 0.09 & 0.28 & 0.36 & 0.011 & 25.0 & 0 & 277 & 0.0 & - & -25.0 \\
\hline $65-4,107$ & 11.2 & 8.5 & 0.71 & 1.81 & 2.08 & 0.062 & 29.0 & 25 & 64 & 0.0 & 417 & -25.1 \\
\hline $65-4,113$ & 82.0 & 83.3 & 0.10 & 0.19 & 0.37 & 0.006 & 32.0 & 0 & 232 & 0.0 & - & -25.2 \\
\hline $66-3,25$ & 90.4 & 89.4 & 0.06 & 0.12 & - & 0.005 & 24.0 & - & - & - & - & - \\
\hline $66-3,32$ & 72.1 & 72.4 & 0.18 & 0.54 & 0.96 & 0.016 & 34.0 & 35 & 122 & 0.0 & 416 & -26.0 \\
\hline $66-3,35$ & 24.8 & 22.2 & 0.81 & 2.24 & 2.79 & 0.086 & 26.0 & 43 & 53 & 0.0 & 423 & -25.7 \\
\hline $66-3,44$ & 89.5 & 89.5 & 0.21 & 0.71 & - & 0.024 & 30.0 & - & - & - & - & - \\
\hline $66-3,59$ & 75.0 & 74.6 & 0.06 & 0.18 & - & 0.008 & 23.0 & - & - & - & - & - \\
\hline $67-4,126$ & 18.6 & 16.5 & 0.81 & 2.45 & 2.82 & 0.089 & 28.0 & 43 & 58 & 0.0 & 422 & -25.7 \\
\hline $75-2,34$ & 70.7 & 70.3 & 0.11 & 0.24 & 0.44 & 0.010 & 24.0 & 9 & 225 & 0.3 & 412 & -24.8 \\
\hline $75-2,48$ & 24.6 & 15.3 & 0.64 & 1.58 & 1.48 & 0.048 & 33.0 & 37 & 76 & 0.1 & 414 & -24.7 \\
\hline $75-2,48$ & 24.5 & 21.6 & - & 1.27 & - & 0.045 & 28.0 & - & - & - & - & - \\
\hline $75-2,61$ & 25.9 & 22.4 & 0.43 & 1.43 & 2.10 & 0.048 & 30.0 & 36 & 65 & 0.1 & 416 & -24.8 \\
\hline $75-2,70$ & 66.3 & 65.3 & 0.32 & 1.07 & 1.59 & 0.029 & 37.0 & 62 & 90 & 0.0 & 425 & -25.5 \\
\hline $75-2,86$ & 69.6 & 68.9 & 0.10 & 0.47 & 0.68 & 0.014 & 34.0 & 23 & 170 & 0.1 & 409 & -24.9 \\
\hline $75-2,99$ & 56.4 & 54.4 & 0.84 & 2.05 & 2.61 & 0.068 & 30.0 & 153 & 67 & 0.0 & 422 & -25.3 \\
\hline $75-2,114$ & 14.5 & 13.2 & 0.64 & 1.70 & 2.30 & 0.047 & 36.0 & 41 & 59 & 0.1 & 420 & -24.5 \\
\hline
\end{tabular}


cholke and Vogt, 1979) or to a more complex set of factors, such as changes in climate, sediment input, carbonate productivity, and bottom-water circulation during the mid-Cretaceous.

\section{Lithology of Neocomian Carbonates at Site $\mathbf{6 0 3}$}

The $\mathrm{CaCO}_{3}$ content of the Neocomian carbonate samples from Hole 603B ranges from 11 to $90 \%$, with an average of about $80 \%$ for the laminated to bioturbated light-colored limestones and about $32 \%$ for the black, homogeneous claystones and calcareous claystones (Table 6). Concentrations of $\mathrm{OC}$ average about $0.1 \%$ in bioturbated limestones and $2.24 \%$ in the black claystones, and on a carbonate-free basis there are significant differences between major lithologic types (Table 5).

Four main lithologic types are present as interbeds in the Neocomian carbonates of lithologic Unit V (Fig. 2): (1) bioturbated white to light gray limestone; (2) finely to coarsely laminated, streaked or microburrowed, medium brown to light gray marlstone; (3) homogeneous, dark brown to black claystone and calcareous claystone; and (4) graded to massive, gray to tan siltstone and sandstone (see Site 603 chapter, this volume). The relative proportion of each lithologic type changes with depth: interbedded and bioturbated limestones dominate in the lower part of the sequence (Berriasian to Valanginian) and amounts of terrigenous clastic sediment increase upsection (Fig. 2). In general, laminated carbonate beds predominate over bioturbated limestone beds throughout most of lithologic Unit V. Our studies have concentrated on the interbedded black claystones, laminated marlstones, and bioturbated limestones in several intervals, and in the following discussion we will ignore the coarser-grained clastic units except in so far as they help to interpret depositional processes (see von Rad et al., this volume).

On the basis of visual and gross geochemical criteria, as defined in the following list, the Neocomian carbonates recovered in Hole 603B have two main end-member lithologies and an intermediate, somewhat intergradational lithology (Tables 5, 6, and 9; Fig. 3):

1. Bioturbated white to light gray nannofossil limestone: $70-90 \% \mathrm{CaCO}_{3} ; 0.10-0.4 \%$ OC $(0.58-1.75 \%$ on a carbonate-free basis). Contacts with lithologic type 3 are gradational, whereas those with type 2 typically are sharp.

2. Homogeneous dark brown to black claystone to calcareous claystone: $11-33 \% \mathrm{CaCO}_{3} ; 1.43-2.74 \%$ OC $(1.80-3.19 \%$ on a carbonate-free basis). Contacts with overlying and underlying lithologies typically are sharp, and the black claystones appear to be unbioturbated. The claystones are in contact with lithologic type 3 more commonly than with type 1 .

3. Finely laminated to streaked, medium brown to light gray, microbioturbated to unbioturbated marlstone and limestone: $53-89 \% \mathrm{CaCO}_{3} ; 0.07-3.08 \%$ OC (0.34$7.91 \%$ on a carbonate-free basis). Contacts with both of the other lithologic types are gradational to sharp.

Beds of bioturbated white limestone and black claystone typically are 5 to $15 \mathrm{~cm}$ thick, although some thicker beds do occur. Beds of laminated marlstone and lime- stone usually are thicker (several tens of centimeters) than those of the other lithologies (Fig. 3).

On the basis of lithologic relationships and contents of $\mathrm{CaCO}_{3}$ and $\mathrm{OC}$, the type 3 laminated beds appear to be gradational between types 1 and 2 ; in other words, they are a mixture of nannofossil carbonate and low-carbonate, clay-rich lithologies. Their inorganic geochemical characteristics also are gradational, as we will show. An example of the types of interbedding of the three lithologies is shown in Figure 3 (Core 69, Hole 603B). Figure 4 illustrates the differences in $\mathrm{CaCO}_{3}$ and $\mathrm{OC}$ concentrations for the three lithologic types on the basis of our set of 44 samples, about evenly divided between the three lithologic types (Table 9). Note the distinct cluster of black claystones with relatively high $\mathrm{OC}$ and low $\mathrm{CaCO}_{3}$ values. The bioturbated limestones fall within an even tighter cluster, with low $\mathrm{OC}$ and high $\mathrm{CaCO}_{3}$ values. The laminated (type 3) carbonates have $\mathrm{OC}$ and $\mathrm{CaCO}_{3}$ values intermediate between the other two lithologic types, but closer to, and overlapping with, the bioturbated limestones. The laminated carbonates contain high concentrations of $\mathrm{OC}$ on a whole-rock basis (Tables 6 and 9), and as a group contain the highest OC concentrations on a carbonate-free basis (Table 5).

\section{Characteristics of Organic Matter}

The type and degree of preservation of organic matter also varies with lithology. Figure 5 shows that the Rock-Eval hydrogen index of all samples studied is low ( $<170 \mathrm{mg} \mathrm{HC} / \mathrm{g} \mathrm{OC}$ ) compared with Neocomian bioturbated white limestones and laminated black marlstones from Site 367 (Dean et al., 1986). Highest values of HI occur in the OC-rich transitional laminated marlstones and limestones (type 3), whereas the bioturbated limestones contain organic matter with low $\mathrm{HI}$ and high OI. The black claystones cluster with low values of both HI and OI. Note that the HI values for all Site 367 samples are higher for both the oxidized (bioturbated white limestone) and reduced (laminated black marlstone) lithologies. In the samples from both Site 603 (Fig. 6) and Site 367 there is a strong positive correlation between percentage $\mathrm{OC}$ and $\mathrm{HI}$, a commonly observed relationship in OC-rich strata (e.g., Dean et al., 1986). This relationship implies that sediments with higher concentrations of organic matter tend to be more hydrogen-rich, or, to put it another way, that increases in OC above about $1 \%$ result from the enhanced preservation of $\mathrm{H}$-rich marine organic matter. Plots of absolute percent amorphous organic matter versus percent $O C$ for the western North Atlantic (Summerhayes, 1981) illustrate this same effect; there appears to be a fairly constant background of about 0.5 to $1.0 \%$ terrestrial or reworked OC, and values above about $1.0 \% \mathrm{OC}$ are due mainly to the addition and/or enhanced preservation of amorphous autochthonous marine organic matter.

The stable carbon-isotope composition of OC often has been interpreted in terms of the source of the organic matter. The basis for interpreting the isotopic composition of $\mathrm{OC}$ as a source signal is that modern terrestrial vegetation generally is depleted in ${ }^{13} \mathrm{C}$ relative to modern marine plankton, and generally has $\delta^{13} \mathrm{C}$ values about 5 
Table 4. Inorganic and organic geochemical analyses of postcruise samples from Hole 603B.

\begin{tabular}{|c|c|c|c|c|c|c|c|c|c|c|c|c|c|c|c|c|}
\hline $\begin{array}{l}\text { Core-Section } \\
\text { interval }(\mathrm{cm})\end{array}$ & $\begin{array}{c}\mathrm{Al}_{2} \mathrm{O}_{3} \\
(\%)\end{array}$ & $\begin{array}{c}\mathrm{Fe}_{2} \mathrm{O}_{3} \\
(\%))\end{array}$ & $\begin{array}{c}\mathrm{MgO} \\
(\%)\end{array}$ & $\begin{array}{l}\mathrm{CaO} \\
(\%)\end{array}$ & $\underset{(\%)}{\mathrm{Na}_{2} \mathrm{O}}$ & $\begin{array}{r}\mathrm{K}_{2} \mathrm{O} \\
(\%)\end{array}$ & $\begin{array}{l}\mathrm{TiO}_{2} \\
(\%)\end{array}$ & $\begin{array}{c}\mathrm{P}_{2} \mathrm{O}_{5} \\
(\%)\end{array}$ & $\begin{array}{c}\mathrm{MnO} \\
(\%)\end{array}$ & $\begin{array}{l}\text { As } \\
(\mathrm{ppm})\end{array}$ & $\begin{array}{c}\mathrm{Ba} \\
(\mathrm{ppm})\end{array}$ & $\begin{array}{c}\mathrm{Be} \\
(\mathrm{ppm})\end{array}$ & $\underset{(\mathrm{ppm})}{\mathrm{Cd}}$ & $\begin{array}{c}\text { Co } \\
\text { (ppm) }\end{array}$ & $\begin{array}{c}\mathrm{Cr} \\
(\mathrm{ppm})\end{array}$ & $\underset{(\mathrm{ppm})}{\mathrm{Cu}}$ \\
\hline $35-1,23$ & 20.8 & 3.00 & 4.64 & 0.73 & 2.43 & 1.18 & 0.30 & 0.05 & 0.07 & $<10$ & 140 & 1 & $<2$ & 9 & 80 & 9 \\
\hline $35-1,30$ & 18.9 & 6.44 & 2.16 & 0.63 & 1.33 & 2.76 & 0.83 & 0.07 & 0.04 & $<10$ & 360 & 3 & $<2$ & 25 & 140 & 33 \\
\hline $35-1,49$ & 15.3 & 11.87 & 1.82 & 0.53 & 1.62 & 3.00 & 0.62 & 0.11 & 0.03 & 20 & 450 & 3 & $<2$ & 49 & 160 & 94 \\
\hline $35-2,18$ & 12.7 & 7.01 & 1.66 & 0.62 & 2.02 & 2.64 & 0.50 & 0.16 & 0.03 & 10 & 140 & 3 & 2 & 35 & 200 & 130 \\
\hline $35-2,47$ & 13.6 & 8.44 & 1.44 & 0.76 & 1.35 & 2.52 & 0.67 & 0.07 & 0.03 & $<10$ & 500 & 2 & $<2$ & 26 & 97 & 66 \\
\hline $35-2,128$ & 16.2 & 5.43 & 1.99 & 0.53 & 1.75 & 3.00 & 0.70 & 0.09 & 0.04 & $<10$ & 950 & 2 & $<2$ & 14 & 100 & 85 \\
\hline $36-3,8$ & 18.9 & 5.86 & 2.32 & 0.62 & 1.62 & 3.24 & 0.80 & 0.11 & 0.02 & $<10$ & 430 & 3 & $<2$ & 16 & 150 & 87 \\
\hline $36-3,13$ & 20.8 & 6.58 & 2.49 & 0.64 & 1.75 & 3.48 & 0.85 & 0.11 & 0.02 & $<10$ & 480 & 3 & $<2$ & 17 & 120 & 83 \\
\hline $36-3,17$ & 22.7 & 6.44 & 1.99 & 0.48 & 1.48 & 3.00 & 0.92 & 0.09 & 0.02 & 10 & 420 & 4 & $<2$ & 36 & 170 & 55 \\
\hline $36-3,21$ & 20.8 & 8.29 & 2.16 & 0.53 & 1.35 & 2.88 & 0.83 & 0.09 & 0.02 & $<10$ & 430 & 3 & $<2$ & 25 & 170 & 63 \\
\hline $36-3,27$ & 22.7 & 6.58 & 2.32 & 0.56 & 1.48 & 3.12 & 0.88 & 0.09 & 0.02 & $<10$ & 410 & 4 & $<2$ & 21 & 170 & 61 \\
\hline $36-3,35$ & 20.8 & 7.58 & 2.49 & 0.69 & 1.89 & 3.72 & 0.80 & 0.16 & 0.03 & $<10$ & 670 & 3 & $<2$ & 21 & 130 & 110 \\
\hline $36-3,49$ & 17.4 & 5.43 & 2.32 & 0.73 & 1.62 & 2.52 & 0.70 & 0.16 & 0.02 & 20 & 380 & 2 & 5 & 18 & 170 & 99 \\
\hline $36-3,57$ & 17.2 & 5.58 & 2.32 & 0.81 & 1.62 & 2.52 & 0.70 & 0.21 & 0.02 & 20 & 650 & 2 & $<2$ & 25 & 130 & 92 \\
\hline $36-3,70$ & 20.8 & 8.29 & 2.49 & 0.56 & 1.62 & 3.12 & 0.92 & 0.11 & 0.03 & $<10$ & 420 & 4 & $<2$ & 20 & 130 & 82 \\
\hline $37-1,30$ & 13.8 & 38.61 & 1.51 & 0.57 & 1.08 & 2.04 & 0.53 & 0.05 & 0.01 & 50 & 320 & 2 & $<2$ & 55 & 100 & 41 \\
\hline $37-1,33$ & 20.8 & 6.72 & 2.65 & 0.57 & 1.62 & 3.24 & 0.85 & 0.14 & 0.02 & $<10$ & 470 & 3 & $<2$ & 20 & 160 & 120 \\
\hline $37-5,104$ & 17.6 & 5.72 & 2.16 & 0.70 & 1.75 & 3.24 & 0.77 & 0.11 & 0.02 & 10 & 480 & 3 & $<2$ & 22 & 190 & 65 \\
\hline $37-5,107$ & 18.9 & 6.58 & 2.49 & 0.63 & 1.62 & 3.12 & 0.82 & 0.16 & 0.03 & 20 & 430 & 3 & $<2$ & 44 & 130 & 150 \\
\hline $37-5,111$ & 20.8 & 6.72 & 2.32 & 0.66 & 1.62 & 3.36 & 0.87 & 0.09 & 0.05 & 10 & 450 & 4 & $<2$ & 64 & 120 & 94 \\
\hline $38-1,146$ & 14.9 & 8.29 & 1.99 & 0.92 & 1.48 & 2.64 & 0.68 & 0.25 & 0.07 & 70 & 370 & 2 & 7 & 50 & 130 & 110 \\
\hline $38-1,146$ & 15.3 & 8.58 & 2.16 & 0.94 & 1.62 & 2.64 & 0.70 & 0.25 & 0.08 & 70 & 370 & 2 & 7 & 51 & 120 & 120 \\
\hline $38-2,8$ & 18.9 & 7.29 & 2.32 & 0.48 & 1.62 & 2.88 & 0.87 & 0.09 & 0.04 & 30 & 410 & 3 & $<2$ & 47 & 130 & 88 \\
\hline $38-2,8$ & 20.8 & 7.29 & 2.32 & 0.49 & 1.75 & 3.48 & 0.88 & 0.09 & 0.04 & 30 & 420 & 3 & $<2$ & 48 & 210 & 90 \\
\hline $38-2,18$ & 18.9 & 7.01 & 2.49 & 0.84 & 1.75 & 3.00 & 0.82 & 0.16 & 0.06 & 30 & 400 & 4 & $<2$ & 57 & 120 & 120 \\
\hline $38-2,22$ & 17.6 & 5.43 & 2.16 & 0.59 & 1.48 & 2.76 & 0.78 & 0.14 & 0.03 & 40 & 390 & 3 & $<2$ & 83 & 120 & 97 \\
\hline $38-2,25$ & 16.2 & 4.86 & 1.82 & 0.56 & 1.62 & 2.88 & 0.80 & 0.11 & 0.03 & $<10$ & 420 & 2 & $<2$ & 31 & 110 & 98 \\
\hline $66-3,3$ & 1.1 & 1.03 & 0.56 & 49.00 & 0.15 & 0.18 & 0.03 & 0.05 & 0.34 & $<10$ & 37 & $<1$ & $<2$ & 2 & 11 & 15 \\
\hline $66-3,40$ & 1.2 & 1.57 & 0.61 & 46.20 & 0.20 & 0.24 & 0.05 & 0.05 & 0.25 & $<10$ & 43 & $<1$ & $<2$ & 9 & 14 & 27 \\
\hline $66-3,51$ & 1.1 & 0.94 & 0.56 & 43.40 & 0.13 & 0.17 & 0.03 & 0.07 & 0.28 & $<10$ & 39 & $<1$ & $<2$ & 4 & 13 & 13 \\
\hline $66-3,51$ & 1.3 & 1.06 & 0.63 & 49.00 & 0.24 & 0.22 & 0.05 & 0.07 & 0.32 & $<10$ & 43 & $<1$ & $<2$ & 3 & 6 & 12 \\
\hline $66-3,68$ & 18.9 & 5.01 & 2.49 & 8.40 & 1.23 & 2.76 & 0.72 & 0.07 & 0.02 & $<10$ & 310 & 2 & $<2$ & 23 & 86 & 52 \\
\hline $69-2,133$ & 13.8 & 5.15 & 2.32 & 11.20 & 1.48 & 2.88 & 0.65 & 0.07 & 0.03 & $<10$ & 320 & 1 & $<2$ & 26 & 130 & 53 \\
\hline $69-2,143$ & 14.0 & 5.58 & 2.32 & 10.50 & 1.48 & 2.64 & 0.67 & 0.07 & 0.04 & $<10$ & 330 & 1 & $<2$ & 30 & 110 & 54 \\
\hline $69-3,7$ & 1.2 & 0.94 & 0.50 & 49.00 & 0.11 & 0.13 & 0.05 & 0.05 & 0.43 & $<10$ & 42 & $<1$ & $<2$ & 4 & 74 & 17 \\
\hline $69-3,19$ & 1.4 & 1.10 & 0.51 & 47.60 & 0.28 & 0.30 & 0.05 & 0.05 & 0.43 & $<10$ & 48 & $<1$ & $<2$ & 4 & 7 & 24 \\
\hline $69-3,27$ & 1.7 & 1.16 & 0.53 & 47.60 & 0.18 & 0.28 & 0.07 & 0.07 & 0.39 & $<10$ & 54 & $<1$ & $<2$ & 5 & 89 & 14 \\
\hline $69-3,42$ & 2.5 & 1.42 & 0.65 & 44.80 & 0.43 & 0.53 & 0.10 & 0.14 & 0.30 & $<10$ & 82 & $<1$ & $<2$ & 17 & 19 & 48 \\
\hline $69-3,48$ & 2.5 & 1.57 & 0.63 & 44.80 & 0.39 & 0.47 & 0.10 & 0.11 & 0.32 & $<10$ & 74 & $<1$ & $<2$ & 14 & 15 & 33 \\
\hline $69-3,57$ & 1.4 & 1.06 & 0.48 & 43.40 & 0.13 & 0.19 & 0.05 & 0.09 & 0.36 & $<10$ & 50 & $<1$ & $<2$ & 4 & 35 & 17 \\
\hline $69-3,66$ & 1.3 & 1.13 & 0.50 & 49.00 & 0.13 & 0.19 & 0.05 & 0.07 & 0.41 & $<10$ & 46 & $<1$ & $<2$ & 4 & 33 & 18 \\
\hline $69-3,71$ & 1.5 & 1.10 & 0.46 & 43.40 & 0.24 & 0.26 & 0.05 & 0.07 & 0.35 & $<10$ & 55 & $<1$ & $<2$ & 5 & 9 & 11 \\
\hline $69-3,71$ & 1.7 & 1.23 & 0.51 & 47.60 & 0.22 & 0.28 & 0.07 & 0.07 & 0.37 & $<10$ & 59 & $<1$ & $<2$ & 5 & 53 & 17 \\
\hline
\end{tabular}

Note: $\mathrm{CaCO}_{3}-\mathrm{Ca}=$ concentration of $\mathrm{CaCO}_{3}$ calculated from total $\mathrm{Ca}$ concentration; $\mathrm{CaCO}_{3}-\mathrm{MA}=\mathrm{CaCO}_{3}$ concentration determined at Univ. of Rhode Island; OC-MA = organic carbon concentration determined at Univ. of Rhode Island; OC-RE = organic carbon concentration determined by Rock-Eval pyrolysis; $\mathrm{N}$ MA and C/N-MA, nitrogen and C/N ration determined at Univ. of Rhode Island; Prod-I = production index (see "Methods"); $\mathrm{T}_{\max }=$ temperature of maximum yield of pyrolitic hydrocarbons. Dashes indicate no analysis. Samples with the same core-section, interval designation are analytical duplicates, as indicated in Table 2.

to $6 \%$ lighter (more negative) than those of marine plankton (e.g., Deines, 1980). Most organic matter in modern marine sediments, judged by other geochemical criteria to be mainly marine, has $\delta^{13} \mathrm{C}$ values similar to those of marine plankton and particulate organic matter (about $-22 \%$ ). This relationship also appears to be true of organic matter at least as far back as the Miocene (see Arthur, Dean, and Claypool, 1985; Dean et al., 1986). We therefore expected that the isotopic composition of the OC-rich strata at Site 603, particularly when compared with that of the same facies at Site 367, would be consistent with the results of other geochemical source indicators, such as Rock-Eval pyrolysis. In other words, the $\mathrm{OC}$ at Site 603, being mostly terrestrial, should be isotopically lighter (have more negative values of $\delta^{13} \mathrm{C}$ ) then that at Site 367, which is mostly marine [Tissot et al., 1979, 1980; Summerhayes, 1981, 1986]). Figure 7 shows that the opposite is true; the organic matter from Site 603 is isotopically heavier than the more marine, more $\mathrm{H}$-rich organic matter at Site 367 . In fact, the organic matter in the most OC-rich black marlstone beds at Site 367 is most enriched in hydrogen and is isotopically lightest, whereas the organic matter in the black claystone beds at Site 603 is the least enriched in hydrogen and is isotopically heaviest.

The $\delta^{13} \mathrm{C}$ values of the $\mathrm{OC}$ at Site 367 are similar to those for other Cretaceous marine OC-rich strata (Dean et al., 1986). The $\delta^{13} \mathrm{C}$ values of the OC at Site 603, particularly in the black claystones, are similar to those for other Cretaceous terrestrial OC-rich strata, such as coals. Arthur, Dean, and Claypool (1985) and Dean et al. (1986) concluded that the isotopic composition of Cretaceous organic matter was indeed recording a source signal, but that this source signal was very different from that of modern organic matter. Cretaceous marine $\mathrm{OC}$ had $\delta^{13} \mathrm{C}$ values of about -27 to $-29 \%$, and Cretaceous terrestrial OC had $\delta^{13} \mathrm{C}$ values of about -23 to $-25 \%$. This conclusion is illustrated particularly well in the comparison of $\delta^{13} \mathrm{C}$ and $\mathrm{HI}$ values from Sites 603 and 367 in Figure 7. 
Table 4 (continued).

\begin{tabular}{|c|c|c|c|c|c|c|c|c|c|c|c|c|c|c|c|}
\hline$\underset{(\mathrm{ppm})}{\mathrm{La}}$ & $\begin{array}{c}\text { Mo } \\
(\mathrm{ppm})\end{array}$ & $\begin{array}{c}\mathrm{Nb} \\
(\mathrm{ppm})\end{array}$ & $\begin{array}{c}\mathrm{Ni} \\
(\mathrm{ppm})\end{array}$ & $\begin{array}{c}\mathrm{Pb} \\
(\mathrm{ppm})\end{array}$ & $\underset{(\mathrm{ppm})}{\mathrm{Sc}}$ & $\underset{(\mathrm{ppm})}{\mathrm{Sr}}$ & $\begin{array}{c}\mathrm{V} \\
(\mathrm{ppm})\end{array}$ & $\begin{array}{c}\mathrm{Y} \\
\text { (ppm) }\end{array}$ & $\underset{(\mathrm{ppm})}{\mathrm{Zn}}$ & $\begin{array}{c}\mathrm{Ce} \\
(\mathrm{ppm})\end{array}$ & $\begin{array}{c}\mathrm{Ga} \\
\text { (ppm) }\end{array}$ & $\begin{array}{c}\mathrm{Li} \\
\text { (ppm) }\end{array}$ & $\begin{array}{c}\text { Th } \\
(\mathrm{ppm})\end{array}$ & $\begin{array}{c}\mathrm{Yb} \\
\text { (ppm) }\end{array}$ & $\begin{array}{c}\mathrm{Nd} \\
(\mathrm{ppm})\end{array}$ \\
\hline 130 & 7 & 55 & 81 & 34 & 3 & 290 & 43 & 15 & 320 & 260 & 28 & 110 & 35 & 1 & 46 \\
\hline 42 & $<2$ & 28 & 100 & 44 & 17 & 190 & 130 & 15 & 130 & 82 & 29 & 81 & 19 & 2 & 33 \\
\hline 34 & 11 & 19 & 290 & 42 & 13 & 270 & 190 & 17 & 100 & 70 & 21 & 59 & 11 & 2 & 26 \\
\hline 31 & 6 & 7 & 150 & 36 & 12 & 410 & 420 & 26 & 430 & 62 & 18 & 36 & 8 & 2 & 28 \\
\hline 31 & 2 & 12 & 76 & 42 & 12 & 270 & 100 & 15 & 140 & 64 & 17 & 48 & 10 & 2 & 24 \\
\hline 37 & $<2$ & 13 & 50 & 34 & 14 & 310 & 110 & 18 & 78 & 82 & 21 & 49 & 10 & 2 & 28 \\
\hline 43 & $<2$ & 15 & 70 & 31 & 16 & 200 & 130 & 19 & 130 & 93 & 25 & 73 & 11 & 2 & 34 \\
\hline 42 & $<2$ & 19 & 83 & 37 & 17 & 230 & 150 & 20 & 140 & 98 & 27 & 82 & 11 & 2 & 33 \\
\hline 42 & 7 & 17 & 110 & 39 & 17 & 180 & 150 & 16 & 160 & 96 & 30 & 110 & 13 & 2 & 31 \\
\hline 41 & 7 & 20 & 100 & 37 & 17 & 200 & 160 & 17 & 140 & 96 & 29 & 94 & 13 & 2 & 32 \\
\hline 41 & 8 & 22 & 72 & 32 & 17 & 190 & 190 & 17 & 150 & 92 & 31 & 100 & 25 & 2 & 44 \\
\hline 40 & $<2$ & 16 & 79 & 35 & 18 & 270 & 180 & 21 & 370 & 92 & 29 & 81 & 13 & 2 & 36 \\
\hline 35 & 6 & 13 & 100 & 38 & 14 & 230 & 620 & 24 & 2200 & 73 & 23 & 56 & 11 & 2 & 31 \\
\hline 37 & 8 & 14 & 110 & 34 & 14 & 280 & 540 & 29 & 470 & 80 & 23 & 51 & 11 & 2 & 35 \\
\hline 40 & $<2$ & 19 & 89 & 38 & 17 & 180 & 160 & 17 & 130 & 96 & 29 & 99 & 14 & 2 & 32 \\
\hline 31 & 7 & 7 & 340 & 120 & 13 & 180 & 93 & 9 & 190 & 62 & 17 & 68 & 16 & 1 & 27 \\
\hline 41 & $<2$ & 18 & 90 & 51 & 18 & 210 & 150 & 22 & 220 & 100 & 29 & 79 & 14 & 2 & 42 \\
\hline 39 & 12 & 13 & 110 & 32 & 15 & 240 & 120 & 19 & 130 & 84 & 23 & 71 & 10 & 2 & 31 \\
\hline 38 & 2 & 19 & 150 & 32 & 16 & 250 & 140 & 24 & 410 & 92 & 26 & 60 & 12 & 2 & 39 \\
\hline 39 & 2 & 18 & 200 & 41 & 17 & 230 & 170 & 18 & 290 & 92 & 29 & 100 & 12 & 2 & 30 \\
\hline 45 & 15 & 23 & 270 & 47 & 13 & 210 & 1100 & 41 & 1300 & 91 & 23 & 45 & 7 & 3 & 35 \\
\hline 45 & 17 & 27 & 270 & 43 & 13 & 210 & 1100 & 39 & 1400 & 91 & 24 & 45 & 13 & 3 & 39 \\
\hline 38 & 9 & 27 & 160 & 38 & 16 & 180 & 160 & 17 & 200 & 81 & 26 & 85 & 12 & 2 & 28 \\
\hline 38 & 16 & 25 & 180 & 39 & 16 & 180 & 160 & 16 & 200 & 82 & 29 & 93 & 14 & 2 & 31 \\
\hline 38 & $<2$ & 16 & 160 & 42 & 16 & 220 & 180 & 24 & 430 & 86 & 27 & 69 & 11 & 2 & 31 \\
\hline 34 & $<2$ & 16 & 190 & 36 & 15 & 200 & 130 & 22 & 410 & 83 & 25 & 57 & 11 & 2 & 34 \\
\hline 37 & 5 & 13 & 86 & 35 & 15 & 190 & 120 & 20 & 170 & 79 & 22 & 58 & 11 & 2 & 32 \\
\hline 6 & $<2$ & $<4$ & 9 & 46 & $<2$ & 450 & 7 & 8 & 9 & 13 & 5 & 19 & $<4$ & $<1$ & 8 \\
\hline 13 & $<2$ & $<4$ & 20 & 47 & $<2$ & 590 & 13 & 13 & 33 & 24 & $<4$ & 30 & $<4$ & 1 & 15 \\
\hline 10 & $<2$ & $<4$ & 9 & 42 & $<2$ & 490 & 9 & 13 & 18 & 21 & $<4$ & 19 & $<4$ & 1 & 11 \\
\hline 12 & $<2$ & $<4$ & 6 & 48 & $<2$ & 550 & 10 & 14 & 19 & 22 & 5 & 11 & $<4$ & 1 & 14 \\
\hline 24 & $<2$ & 13 & 53 & 47 & 14 & 400 & 130 & 7 & 120 & 45 & 26 & 100 & 14 & 1 & 18 \\
\hline 21 & $<2$ & 5 & 65 & 38 & 15 & 440 & 110 & 8 & 120 & 40 & 21 & 50 & 8 & 1 & 18 \\
\hline 20 & 8 & 10 & 76 & 41 & 14 & 420 & 110 & 8 & 130 & 38 & 21 & 46 & 7 & 1 & 16 \\
\hline 13 & 6 & $<4$ & 21 & 47 & $<2$ & 530 & 9 & 15 & 12 & 23 & 6 & 15 & $<4$ & 1 & 12 \\
\hline 11 & $<2$ & $<4$ & 7 & 47 & $<2$ & 500 & 11 & 13 & 19 & 17 & 6 & 7 & $<4$ & 1 & 12 \\
\hline 9 & 7 & $<4$ & 27 & 46 & $<2$ & 500 & 12 & 12 & 9 & 18 & 5 & 27 & $<4$ & 1 & 11 \\
\hline 13 & $<2$ & $<4$ & 39 & 52 & $<2$ & 640 & 33 & 13 & 74 & 23 & 6 & 18 & $<4$ & $<1$ & 13 \\
\hline 12 & $<2$ & $<4$ & 33 & 50 & $<2$ & 600 & 21 & 12 & 120 & 21 & 6 & 9 & $<4$ & $<1$ & 12 \\
\hline 7 & $<2$ & $<4$ & 16 & 47 & $<2$ & 470 & 11 & 9 & 23 & 15 & 5 & 30 & $<4$ & $<1$ & 9 \\
\hline 5 & $<2$ & $<4$ & 16 & 47 & $<2$ & 490 & 10 & 10 & 6 & 17 & 5 & 29 & $<4$ & $<1$ & 7 \\
\hline 8 & $<2$ & $<4$ & 11 & 54 & $<2$ & 440 & 11 & 9 & 29 & 13 & 5 & 15 & $<4$ & $<1$ & 8 \\
\hline 9 & 3 & $<4$ & 24 & 49 & $<2$ & 490 & 12 & 11 & 36 & 16 & 5 & 22 & $<4$ & $<1$ & 11 \\
\hline
\end{tabular}

A similar pattern of an isotopically heavy $\left({ }^{13} \mathrm{C}\right.$-enriched) source signal for Cretaceous organic matter along the continental margin of the North America, but even closer to a terrestrial organic source, is shown for the Continental Offshore Stratigraphic Test (COST) wells (Scholle, 1977, 1979, 1980; Scholle and Wenkam, 1982; Figs. 1, 8). Most of the Cretaceous samples from the COST wells have atomic $\mathrm{H} / \mathrm{C}$ ratios of 0.6 to 0.8 (Fig. 8 ), characteristic of hydrogen-poor, humic, type III kerogen. Visual estimates of relative abundances of kerogen types show that most of the kerogen is composed of herbaceous, woody, and coaly types. In fact, beds of coal or lignite were described on the basis of the Lower Cretaceous sections in most of these wells. Most of the Cretaceous samples have $\delta^{13} \mathrm{C}$ values of kerogen that range between -24 and $-26 \%$. Thus, the terrestrial organic matter in the Cretaceous sections of the COST wells has an isotopic composition similar to that of the dark, homogeneous, calcareous claystones of lithologic Unit V in Hole 603B.

Figure 9 shows the stratigraphic distribution of $\delta^{13} \mathrm{C}$ and $\mathrm{HI}$ in Cretaceous organic matter in our samples from Hole 603B. The organic matter at the top of the Neocomian carbonate section ( $1300 \mathrm{~m}$ sub-bottom) tends to be isotopically lighter, which we would interpret to indicate a larger contribution of marine organic matter; the organic matter at the bottom of the section $(1500 \mathrm{~m})$ is isotopically heavier, which we would interpret to indicate a larger contribution of terrestrial organic matter. This probably does not represent a secular trend in $\delta^{13} \mathrm{C}$ of oceanic total dissolved carbon, because analyses of pelagic carbonates show increasing $\delta^{13} \mathrm{C}$ through the $\mathrm{Ne}$ ocomian (Scholle and Arthur, 1980). There is no corresponding difference in $\mathrm{HI}$ between the top and bottom of the Neocomian carbonate section, but all values of $\mathrm{HI}$ are low, indicating that the organic matter, regardless of source, is highly oxidized and degraded.

The ratio of organic carbon to total nitrogen $(\mathrm{C} / \mathrm{N})$ also has been used as an indicator of the source of organic matter in modern sediments (e.g., Goodell, 1972; Walsh et al., 1985). Terrestrial organic matter tends to be depleted in proteinaceous, $\mathrm{N}$-rich compounds and enriched in humic, $\mathrm{C}$-rich compounds. Consequently, the $\mathrm{C} / \mathrm{N}$ ratio of terrestrial organic matter tends to be high (about 14-30; Goodell, 1972; Muller, 1977; Meyers et al., 1984; Meyers, this volume) compared with that of freshly deposited, lipid-rich, autochthonous marine organic matter $(\mathrm{C} / \mathrm{N}<10)$. Interpretations based on $\mathrm{C} / \mathrm{N}$ 
Table 4 (continued).

\begin{tabular}{|c|c|c|c|c|c|c|c|c|c|c|c|c|}
\hline $\begin{array}{l}\text { Core-Section } \\
\text { interval }(\mathrm{cm})\end{array}$ & $\mathrm{CaCO}_{3}-\mathrm{Ca}$ & $\mathrm{CaCO}_{3}-\mathrm{MA}$ & Total S & $\begin{array}{c}\text { OC-MA } \\
(\%)\end{array}$ & $\begin{array}{c}\text { OC-RE } \\
(\%)\end{array}$ & $\begin{array}{c}\text { N-MA } \\
(\%)\end{array}$ & $\mathrm{C} / \mathrm{N}-\mathrm{MA}$ & H-Index & O-Index & Prod-I & $\mathrm{T}_{\max }$ & ${ }^{13} \mathrm{C}_{\text {org }}$ \\
\hline $35-1,23$ & 1.3 & 0.0 & - & 0.14 & - & 0.001 & 142.0 & - & - & - & - & - \\
\hline $35-1,30$ & 1.1 & 0.0 & 0.89 & 1.52 & 1.29 & 0.052 & 29.5 & 79 & 48 & 0.10 & 401 & -26.3 \\
\hline $35-1,49$ & 0.9 & 0.0 & 0.73 & 1.67 & - & 0.058 & 29.0 & - & - & - & - & - \\
\hline $35-2,18$ & 1.1 & 0.0 & 3.25 & 4.25 & 4.05 & 0.147 & 28.9 & 119 & 41 & 0.03 & 405 & -26.4 \\
\hline $35-2,47$ & 1.4 & 0.0 & 1.36 & 0.82 & - & 0.031 & 26.4 & - & - & - & - & - \\
\hline $35-2,128$ & 0.9 & 0.0 & 0.59 & 0.17 & 0.13 & 0.014 & 12.3 & 438 & 284 & 0.03 & 450 & -25.6 \\
\hline $36-3,8$ & 1.1 & 0.0 & 0.56 & 0.41 & - & 0.016 & 25.2 & - & - & - & - & - \\
\hline $36-3,13$ & 1.1 & 0.0 & 0.13 & 0.28 & 0.23 & 0.019 & 14.3 & 421 & 113 & 0.08 & 449 & -25.7 \\
\hline $36-3,17$ & 0.9 & 0.0 & 0.99 & 1.71 & - & 0.073 & 23.3 & - & - & - & - & - \\
\hline $36-3,21$ & 0.9 & 0.0 & 0.89 & 1.15 & - & 0.050 & 23.0 & - & - & - & - & - \\
\hline $36-3,27$ & 1.0 & 0.0 & 1.53 & 1.72 & - & 0.076 & 22.6 & - & - & - & - & - \\
\hline $36-3,35$ & 1.2 & 0.0 & 1.85 & 2.00 & - & 0.086 & 23.3 & - & - & - & - & - \\
\hline $36-3,49$ & 1.3 & 0.0 & 1.42 & 4.24 & 4.18 & 0.174 & 24.4 & 169 & 40 & 0.02 & 414 & -26.9 \\
\hline $36-3,57$ & 1.4 & 0.0 & 1.66 & 3.96 & 3.72 & 0.159 & 25.0 & 154 & 44 & 0.02 & 410 & -26.7 \\
\hline $36-3,70$ & 1.0 & 0.0 & 1.26 & 1.46 & 1.42 & 0.062 & 23.5 & 84 & 65 & 0.08 & 404 & -25.9 \\
\hline $37-1,30$ & 1.0 & 0.0 & 0.34 & 0.95 & - & 0.048 & 19.9 & - & - & - & - & - \\
\hline $37-1,33$ & 1.0 & 0.0 & 0.32 & 1.08 & - & 0.051 & 21.1 & - & - & - & - & - \\
\hline $37-5,104$ & 1.3 & 0.0 & 0.29 & 0.47 & 0.42 & 0.026 & 18.2 & 157 & 109 & 0.04 & 419 & - \\
\hline $37-5,107$ & 1.1 & 0.0 & 1.23 & 1.87 & 1.76 & 0.071 & 26.1 & 64 & 43 & 0.03 & 410 & -26.3 \\
\hline $37-5,111$ & 1.2 & 0.0 & 1.10 & 1.48 & - & 0.064 & 23.1 & - & - & - & - & - \\
\hline $38-1,146$ & 1.7 & 0.0 & 1.86 & 5.49 & 5.48 & 0.218 & 25.2 & 173 & 37 & 0.02 & 409 & -27.1 \\
\hline $38-1,146$ & 1.7 & 0.0 & - & - & - & - & - & - & - & - & - & - \\
\hline $38-2,8$ & 0.9 & 0.0 & 0.10 & 0.22 & 0.20 & 0.020 & 11.0 & 370 & 175 & 0.10 & 439 & -25.7 \\
\hline $38-2,8$ & 0.9 & 0.0 & - & - & - & - & - & - & - & - & - & - \\
\hline $38-2,18$ & 1.5 & 0.0 & 1.29 & 2.58 & - & 0.101 & 25.5 & - & - & - & - & - \\
\hline $38-2,22$ & 1.1 & 0.0 & 0.43 & 1.46 & 1.45 & 0.066 & 22.1 & 82 & 53 & 0.06 & 409 & -26.2 \\
\hline $38-2,25$ & 1.0 & 0.0 & 0.20 & 0.25 & 0.20 & 0.031 & 8.0 & 225 & 135 & 0.02 & 436 & -25.5 \\
\hline $66-3,3$ & 87.5 & - & 0.21 & 0.15 & - & 0.050 & 3.0 & - & - & - & - & - \\
\hline $66-3,40$ & 82.5 & 87.8 & 1.25 & 0.91 & - & 0.037 & 24.0 & - & - & - & - & - \\
\hline $66-3,51$ & 77.5 & 91.6 & 0.34 & 0.20 & - & 0.006 & 32.0 & - & - & - & - & - \\
\hline $66-3,51$ & 87.5 & - & - & - & - & - & - & - & - & - & - & - \\
\hline $66-3,68$ & 15.0 & 12.4 & 0.78 & 1.53 & - & 0.058 & 26.0 & - & - & - & - & - \\
\hline $69-2,133$ & 20.0 & 18.5 & 2.01 & 1.59 & - & 0.046 & 35.0 & - & - & - & - & - \\
\hline $69-2,143$ & 18.8 & 16.0 & 1.06 & 1.57 & - & 0.045 & 35.0 & - & - & - & - & - \\
\hline $69-3,7$ & 87.5 & 91.5 & 0.40 & 0.17 & - & 0.004 & 43.0 & - & - & - & - & - \\
\hline $69-3,19$ & 85.0 & 90.8 & 0.42 & 0.10 & - & 0.003 & 33.0 & - & - & - & - & - \\
\hline $69-3,27$ & 85.0 & 89.5 & 0.28 & 0.14 & - & 0.005 & 28.0 & - & - & - & - & - \\
\hline $69-3,42$ & 80.0 & 83.1 & 1.58 & 0.90 & - & 0.033 & 27.0 & - & - & - & - & - \\
\hline $69-3,48$ & 80.0 & 84.9 & 0.25 & 0.07 & - & 0.016 & 4.0 & - & - & - & - & - \\
\hline $69-3,57$ & 77.5 & 89.7 & 0.63 & 0.23 & - & 0.006 & 38.0 & - & - & - & - & - \\
\hline $69-3,66$ & 87.5 & 90.5 & 0.83 & 0.13 & - & 0.004 & 33.0 & - & - & - & - & - \\
\hline $69-3,71$ & 77.5 & 88.8 & 0.46 & 0.13 & - & 0.004 & 33.0 & - & - & - & - & - \\
\hline $69-3,71$ & 85.0 & - & - & - & - & - & - & - & - & - & - & - \\
\hline
\end{tabular}

ratios alone may be misleading, however (e.g., Waples, 1985), because of selective consumption of N-bearing organic compounds during the decomposition of organic matter, and because a substantial portion of the nitrogen in some samples may be adsorbed inorganic nitrogen. This adsorbed nitrogen usually is in the form of $\mathrm{NH}_{3}$ or $\mathrm{NH}_{4}{ }^{+}$fixed on clays. Consequently, the most serious errors in using $\mathrm{C} / \mathrm{N}$ ratios as indicators of organic matter source would occur in sediments rich in clay and poor in organic matter. That the $\mathrm{C} / \mathrm{N}$ ratios of all Neocomian lithologies from Site 603, regardless of clay content, are close to 30 (Fig. 10) suggests that most of the nitrogen in these samples is organic nitrogen, that the source of this nitrogen was mainly terrestrial organic matter, and/or that the organic matter is highly degraded. In any case, the $\mathrm{C} / \mathrm{N}$ ratio does not appear to be a very useful index of either source or preservation of organic matter in ancient sedimentary rocks.

The carbonate-rich lithologies of lithologic Unit $\mathrm{V}$ tend to be enriched in sulfur and phosphate $\left(\right.$ as $\mathrm{P}_{2} \mathrm{O}_{5}$; Table 5 ), which also may be related to initial source and degree of preservation of organic matter. The mean concentration of sulfur in the carbonate lithologies is raised by a few very high values. Even without these few high-S samples, Figure 11 shows that the carbonates tend to be somewhat enriched in sulfur, on a carbonate-free basis, relative to the claystones, although there is considerable overlap in the ranges of $\mathrm{S}$ concentration among the three lithologic types. Figure 11 shows that the $\mathrm{P}_{2} \mathrm{O}_{5}$ contents of the black claystones are distinctly lower than those of the carbonate lithologies. The average $\mathrm{P}_{2} \mathrm{O}_{5}$ concentration in the black claystones is $0.1 \%$, about the same as the average $\mathrm{P}_{2} \mathrm{O}_{5}$ concentration in claystones of lithologic Unit IV (Table 7; discussed shortly), regardless of organic carbon content. The carbonate lithologies, on the other hand, contain several times more $\mathrm{P}_{2} \mathrm{O}_{5}$ on a carbonate-free basis than the black claystones, although there is no distinction by $\mathrm{P}_{2} \mathrm{O}_{5}$ content between the laminated and bioturbated carbonates (Fig. 11).

The amount of phosphorus that can be buried in sediment, other than that associated with detrital mineral phases, is limited by the initial $\mathrm{C} / \mathrm{P}$ ratio in the organic matter that reaches the sediment/water interface, as well as the different rates of removal of organic carbon and phosphorus during aerobic and anaerobic decomposition of organic matter (Froelich et al., 1979). Phosphorus, like organic nitrogen, tends to be preferentially removed relative to carbon by decay of organic detritus as 
Table 5. Summary statistics for concentrations of major-element oxides and trace elements on a carbonate-free basis in samples of white limestone, black claystone, and laminated transitional marlstone and limestone from lithologic Unit V, Hole 603B.

\begin{tabular}{|c|c|c|c|c|c|c|c|c|c|c|c|c|c|c|c|}
\hline \multirow[b]{2}{*}{ Component } & \multicolumn{5}{|c|}{ Bioturbated white limestones } & \multicolumn{5}{|c|}{ Laminated marlstones and limestones } & \multicolumn{5}{|c|}{ Homogeneous black claystones } \\
\hline & Min. & Max. & GM & GD & $N$ & Min. & Max. & GM & GD & $N$ & Min. & Max. & GM & GD & $N$ \\
\hline \multicolumn{16}{|l|}{ Oxide $(\%)$} \\
\hline $\mathrm{SiO}_{2}$ & 49.25 & 61.46 & 53.85 & 1.081 & 8 & 40.07 & 54.56 & 47.08 & 1.147 & 9 & 51.74 & 55.19 & 53.24 & 1.026 & 13 \\
\hline $\mathrm{Al}_{2} \mathrm{O}_{3}$ & 5.04 & 17.76 & 12.21 & 1.504 & 14 & 6.30 & 16.33 & 12.58 & 1.344 & 14 & 15.82 & 22.22 & 18.67 & 1.099 & 16 \\
\hline $\mathrm{Fe}_{2} \mathrm{O}_{3}^{3}$ & 4.19 & 11.51 & 7.23 & 1.284 & 14 & 4.70 & 13.19 & 8.62 & 1.296 & 14 & 5.65 & 9.01 & 6.77 & 1.129 & 16 \\
\hline $\mathrm{MgO}^{3}$ & 2.06 & 6.95 & 4.05 & 1.403 & 14 & 2.14 & 6.07 & 3.67 & 1.308 & 14 & 2.46 & 3.25 & 2.86 & 1.072 & 16 \\
\hline $\mathrm{Na}_{2} \mathrm{O}$ & 0.60 & 2.07 & 1.32 & 1.397 & 14 & 0.60 & 2.16 & 1.49 & 1.375 & 14 & 1.14 & 1.85 & 2.86 & 1.072 & 16 \\
\hline $\mathrm{K}_{2} \mathrm{O}$ & 0.75 & 2.10 & 1.42 & 1.370 & 14 & 0.57 & 2.64 & 1.63 & 1.543 & 14 & 2.61 & 3.60 & 3.04 & 1.099 & 16 \\
\hline $\mathrm{TiO}_{2}$ & 0.15 & 0.53 & 0.36 & 1.427 & 14 & 0.19 & 0.68 & 0.43 & 1.448 & 14 & 0.74 & 0.95 & 0.83 & 1.071 & 16 \\
\hline $\mathrm{P}_{2} \mathrm{O}_{5}$ & 0.23 & 0.73 & 0.38 & 1.341 & 14 & 0.23 & 0.76 & 0.39 & 1.522 & 14 & 0.08 & 0.146 & 0.10 & 1.182 & 16 \\
\hline $\mathrm{MnO}$ & 0.36 & 3.41 & 1.37 & 2.069 & 14 & 0.15 & 2.85 & 0.80 & 2.602 & 14 & 0.02 & 0.07 & 0.04 & 1.497 & 11 \\
\hline OC & 0.58 & 1.75 & 1.05 & 1.394 & 14 & 0.34 & 7.91 & 2.97 & 2.506 & 14 & 1.80 & 3.19 & 2.30 & 1.222 & 16 \\
\hline $\mathrm{T}-\mathrm{N}$ & 0.018 & 0.060 & 0.036 & 1.449 & 14 & 0.027 & 2.66 & 0.111 & 2.131 & 14 & 0.055 & 0.121 & 0.077 & 1.308 & 16 \\
\hline T-S & 0.24 & 6.64 & 0.94 & 2.756 & 14 & 0.64 & 7.90 & 2.03 & 2.109 & 14 & 0.58 & 2.58 & 0.93 & 1.420 & 16 \\
\hline
\end{tabular}

Element (ppm)

\begin{tabular}{|c|c|c|c|c|c|c|c|c|c|c|c|c|c|c|c|}
\hline $\mathrm{Be}$ & $<1$ & - & - & - & 0 & $<1$ & 7 & - & - & 1 & 1.23 & 2.46 & - & - & 6 \\
\hline Co & 16 & 140 & 39 & 2.034 & 14 & 18 & 120 & 56 & 1.759 & 14 & 7 & 68 & 28 & 1.725 & 16 \\
\hline $\mathrm{Cr}$ & 40 & 590 & 130 & 2.373 & 14 & 75 & 590 & 150 & 1.792 & 14 & 34 & 160 & 100 & 1.547 & 16 \\
\hline $\mathrm{Cu}$ & 49 & 250 & 130 & 1.645 & 14 & 75 & 300 & 160 & 1.447 & 14 & 37 & 100 & 67 & 1.245 & 16 \\
\hline $\mathrm{Li}$ & 47 & 310 & 150 & 1.882 & 14 & 45 & 350 & 130 & 1.667 & 14 & 25 & 150 & 73 & 1.604 & 16 \\
\hline $\mathrm{Ni}$ & 40 & 440 & 120 & 2.240 & 14 & 44 & 390 & 160 & 1.746 & 14 & 12 & 190 & 71 & 1.822 & 16 \\
\hline $\mathrm{Pb}$ & $<9$ & 380 & 130 & 2.709 & 11 & $<9$ & 310 & 86 & 2.750 & 12 & 12 & 55 & 24 & 1.625 & 14 \\
\hline $\mathrm{Sc}$ & $<3$ & 66 & - & - & 5 & $<3$ & 54 & - & - & 7 & 6 & 21 & 15 & 1.399 & 16 \\
\hline V & 40 & 570 & 100 & 2.121 & 14 & 49 & 430 & 130 & 1.739 & 14 & 32 & 170 & 110 & 1.606 & 16 \\
\hline $\mathrm{Y}$ & 32 & 120 & 67 & 1.569 & 14 & 9 & 150 & 40 & 2.689 & 14 & 9 & 27 & 13 & 1.381 & 16 \\
\hline $\mathrm{Zn}$ & $<10$ & 520 & 180 & 2.205 & 13 & 60 & 600 & 210 & 1.854 & 14 & 23 & 320 & 120 & 1.675 & 16 \\
\hline $\mathrm{Ce}$ & 58 & 300 & 140 & 1.579 & 14 & 67 & 380 & 140 & 1.687 & 14 & 42 & 73 & 52 & 1.174 & 16 \\
\hline $\mathrm{Ga}$ & 22 & 100 & 44 & 1.570 & 9 & $<9$ & 90 & 34 & 1.553 & 9 & 12 & 34 & 24 & 1.346 & 15 \\
\hline $\mathrm{La}$ & 35 & 130 & 76 & 1.602 & 14 & 31 & 200 & 74 & 1.677 & 14 & 25 & 38 & 30 & 1.134 & 16 \\
\hline Th & $<9$ & 43 & - & - & 2 & $<9$ & 47 & - & - & 2 & 9 & 17 & - & - & 9 \\
\hline Nd & 35 & 240 & 99 & 1.763 & 14 & 40 & 280 & 93 & 1.775 & 14 & 20 & 53 & 31 & 1.349 & 16 \\
\hline
\end{tabular}

Note: The minimum and maximum observed concentrations are given as Min. and Max., respectively. The geometric mean and geometric deviation are given as GM and GD, respectively. $N$ is the total number of samples that contained measurable concentrations greater than the lower detection limit for that element or oxide. Dashes under columns for GM and GD indicate that GM and GD were not calculated, because more than $50 \%$ of samples were below the detection limit for that element (indicated by less-than, <, symbol in Min. column). OC is organic carbon; T-N, total nitrogen; T-S, total sulfur.

Table 6. Summary statistics for concentrations of $\mathrm{CaCO}_{3}$, organic carbon (OC), total nitrogen (T-N), and total sulfur (T-S); Rock-Eval pyrolysis hydrogen index ( $\mathrm{HI}$, in $\mathrm{mg}$ hydrocarbons/g OC), and oxygen index (OI, in $\mathrm{mg} \mathrm{CO} / \mathrm{g} \mathrm{OC})$; and $\delta^{13} \mathrm{C}$ of $\mathrm{OC}$ in parts per thousand relative to the PDB marine carbonate standards in bulk samples of white bioturbated limestone, black claystone, and laminated transitional marlstone and limestone from lithologic Unit V, Hole 603B.

\begin{tabular}{|c|c|c|c|c|c|c|c|c|c|c|c|c|c|c|c|}
\hline \multirow[b]{2}{*}{ Parameter } & \multicolumn{5}{|c|}{ Bioturbated white limestones } & \multicolumn{5}{|c|}{ Laminated marlstones and limestones } & \multicolumn{5}{|c|}{ Homogeneous black claystones } \\
\hline & Min. & Max. & $\bar{x}$ & SD & $N$ & Min. & Max. & $\bar{X}$ & SD & $N$ & Min. & Max. & $\bar{X}$ & SD & $N$ \\
\hline $\mathrm{CaCO}_{3}-\mathrm{MA}(\%)$ & 68.9 & 91.6 & 83.1 & 8.3 & 13 & 52.4 & 89.7 & 76.5 & 13.2 & 14 & 0.0 & 29.9 & 15.8 & 6.6 & 16 \\
\hline $\mathrm{CaCO}_{3}-\mathrm{Ca}(\%)$ & 69.6 & 90.4 & 80.6 & 6.7 & 14 & 52.9 & 89.5 & 74.3 & 11.1 & 14 & 11.2 & 32.5 & 19.5 & 5.5 & 16 \\
\hline OC-MA $(\%)$ & 0.10 & 0.47 & 0.21 & 0.11 & 14 & 0.07 & 3.08 & 1.04 & 0.83 & 14 & 1.43 & 2.74 & 1.89 & 0.40 & 16 \\
\hline T-N (\%) & 0.003 & 0.015 & 0.007 & 0.004 & 14 & 0.005 & 0.086 & 0.035 & 0.025 & 14 & 0.045 & 0.098 & 0.064 & 0.018 & 16 \\
\hline $\mathrm{C} / \mathrm{N}$ & 23 & 43 & 31 & 5.6 & 14 & 4 & 38 & 29 & 8.6 & 14 & 25 & 36 & 30 & 3.5 & 16 \\
\hline T-S (\%) & 0.05 & 0.83 & 0.25 & 0.22 & 14 & 0.13 & 1.58 & 0.63 & 0.46 & 14 & 0.43 & 2.01 & 0.80 & 0.36 & 16 \\
\hline $\mathrm{HI}$ & 0 & 23 & 7 & 10 & 5 & 20 & 153 & 86 & 46 & 8 & 23 & 47 & 35 & 8 & 11 \\
\hline${ }_{113}$ & 170 & 277 & 232 & 40 & 5 & 67 & 184 & 98 & 38 & 8 & 53 & 81 & 64 & 9 & 11 \\
\hline${ }^{{ }^{13} \mathrm{C}}$ & -25.3 & -24.8 & -25.0 & 0.21 & 5 & -26.7 & -25.3 & -26.0 & 0.53 & 8 & -26.7 & -24.4 & -25.3 & 0.68 & 11 \\
\hline
\end{tabular}

Note: The minimum and maximum observed concentrations are given as Min. and Max., respectively. The arithmetic mean and standard deviation are given as $\bar{X}$ and SD, respectively. $\mathrm{N}$ is the total number of samples analyzed. $\mathrm{CaCO}_{3}-\mathrm{MA}$ is $\mathrm{CaCO}_{3}$ concentration determined by the carbonate-bomb method at University of Rhode Island. CaCO $-\mathrm{Ca}$ is $\mathrm{CaCO}_{3}$ concentration calculated from the total $\mathrm{Ca}$ analysis. OC-MA, T-N, and T-S are organic carbon, total nitrogen, and total sulfur, respectively, as determined at the University of Rhode Island.

it settles through the water column and during early diagenesis (Krom and Berner, 1981), so the C/P ratio of organic matter increases systematically (Suess, 1981; Froelich et al., 1982). Therefore, the total phosphorus content of deep-water OC-rich sediment usually is low and the $\mathrm{C} / \mathrm{P}$ ratio high (Glenn and Arthur, 1985).

Average $\mathrm{OC} / \mathrm{P}_{2} \mathrm{O}_{5}$ ratios for black claystones, bioturbated white limestones, and laminated limestones and marlstones are 23,3 , and 12 , respectively, reflecting the higher phosphate content, relative to $\mathrm{OC}$, of the carbonate-rich lithologies. The lower $\mathrm{OC} / \mathrm{P}_{2} \mathrm{O}_{5}$ ratios in the carbonate lithologies could be interpreted as evidence for larger amounts of initially better-preserved marine organic matter in the carbonates. As discussed previously, however, there is little difference in the degree of preservation of organic matter between lithologies, except in the laminated limestones and marlstones, which contain slightly better-preserved organic matter than the biotur- 
Table 7. Summary statistics for concentrations of major-element oxides and trace elements in samples of green, black, and red claystone from lithologic Unit IV, Hole 603B.

\begin{tabular}{|c|c|c|c|c|c|c|c|c|c|c|c|c|c|c|c|}
\hline \multirow[b]{2}{*}{ Component } & \multicolumn{5}{|c|}{ Green claystones } & \multicolumn{5}{|c|}{ Black claystones } & \multicolumn{5}{|c|}{ Red claystones } \\
\hline & Min. & Max. & GM & GD & $N$ & Min. & Max. & GM & GD & $N$ & Min. & Max. & $\mathrm{GM}$ & GD & $N$ \\
\hline \multicolumn{16}{|l|}{ Oxide (\%) } \\
\hline $\mathrm{SiO}_{2}$ & 54.1 & 59.5 & 56.7 & 1.039 & 13 & 50.3 & 62.0 & 55.6 & 1.091 & 5 & 52.1 & 61.6 & 56.1 & 1.066 & 8 \\
\hline $\mathrm{Al}_{2} \mathrm{O}_{3}$ & 16.2 & 21.8 & 18.6 & 1.100 & 20 & 8.4 & 22.7 & 17.2 & 1.258 & 16 & 14.7 & 20.6 & 17.4 & 1.168 & 8 \\
\hline $\mathrm{Fe}_{2} \mathrm{O}_{3}^{3}$ & 4.55 & 8.29 & 6.00 & 1.155 & 20 & 4.23 & 38.6 & 7.19 & 1.553 & 16 & 7.26 & 9.62 & 8.42 & 1.107 & 8 \\
\hline $\mathrm{MgO}^{3}$ & 1.61 & 2.49 & 2.02 & 1.115 & 20 & 0.98 & 2.65 & 2.00 & 1.285 & 16 & 1.55 & 1.96 & 1.77 & 1.093 & 8 \\
\hline $\mathrm{CaO}$ & 0.29 & 0.70 & 0.47 & 1.266 & 20 & 0.31 & 1.16 & 0.60 & 1.396 & 16 & 0.34 & 0.53 & 0.45 & 1.199 & 8 \\
\hline $\mathrm{Na}_{2} \mathrm{O}$ & 0.96 & 1.75 & 1.37 & 1.186 & 20 & 0.98 & 2.02 & 1.46 & 1.214 & 16 & 1.06 & 1.59 & 1.34 & 1.164 & 8 \\
\hline $\mathrm{K}_{2} \mathrm{O}$ & 2.25 & 3.48 & 2.75 & 1.139 & 20 & 1.65 & 3.72 & 2.75 & 1.200 & 16 & 2.41 & 3.08 & 2.81 & 1.102 & 8 \\
\hline $\mathrm{TiO}_{2}$ & 0.70 & 1.13 & 0.86 & 1.105 & 20 & 0.37 & 1.00 & 0.75 & 1.275 & 16 & 0.80 & 0.91 & 0.84 & 1.047 & 8 \\
\hline $\mathrm{P}_{2} \mathrm{O}_{5}$ & 0.08 & 0.14 & 0.11 & 1.198 & 20 & 0.05 & 0.25 & 0.11 & 1.506 & 16 & 0.12 & 0.20 & 0.15 & 1.244 & 8 \\
\hline $\mathrm{MnO}$ & $<0.02$ & 0.140 & 0.030 & 1.661 & 15 & $<0.02$ & 0.075 & 0.031 & 1.486 & 13 & 0.035 & 0.80 & 0.10 & 3.849 & 8 \\
\hline
\end{tabular}

Element (ppm)

\begin{tabular}{|c|c|c|c|c|c|c|c|c|c|c|c|c|c|c|}
\hline $\mathrm{Ba}$ & 300 & 950 & 405 & 1.267 & 20 & 140 & 1000 & 410 & 1.445 & 16 & 300 & 380 & 360 & 1.090 \\
\hline $\mathrm{Be}$ & 2 & 3 & 3 & 1.219 & 20 & $<2$ & 4 & 3 & 1.288 & 16 & 2 & 3 & 2 & 1.206 \\
\hline Co & 14 & 670 & 39 & 3.648 & 20 & 18 & 160 & 35 & 1.777 & 16 & 11 & 34 & 16 & 1.474 \\
\hline $\mathrm{Cr}$ & 99 & 190 & 130 & 1.180 & 20 & 97 & 220 & 140 & 1.229 & 16 & 87 & 120 & 105 & 1.154 \\
\hline $\mathrm{Cu}$ & 32 & 250 & 80 & 1.689 & 20 & 33 & 280 & 88 & 1.646 & 16 & 17 & 81 & 42 & 1.602 \\
\hline $\mathrm{Li}$ & 44 & 100 & 70 & 1.248 & 20 & 21 & 140 & 65 & 1.503 & 16 & 37 & 120 & 64 & 1.438 \\
\hline Mo & $<4$ & 12 & - & - & 4 & $<4$ & 15 & 6 & 1.989 & 13 & $<4$ & - & - & - \\
\hline $\mathrm{Ni}$ & 45 & 810 & 110 & 2.294 & 20 & 66 & 340 & 130 & 1.644 & 16 & 41 & 73 & 58 & 1.251 \\
\hline $\mathrm{Pb}$ & 11 & 39 & 25 & 1.493 & 20 & 15 & 120 & 37 & 1.689 & 16 & 9 & 23 & 13 & 1.325 \\
\hline $\mathrm{Sc}$ & 14 & 21 & 17 & 1.109 & 20 & 9 & 20 & 15 & 1.196 & 16 & 15 & 20 & 18 & 1.094 \\
\hline $\mathrm{Sr}$ & 140 & 310 & 200 & 1.206 & 20 & 120 & 410 & 220 & 1.322 & 16 & 150 & 210 & 180 & 1.135 \\
\hline V & 89 & 270 & 134 & 1.257 & 20 & 93 & 1300 & 230 & 2.209 & 16 & 85 & 160 & 120 & 1.224 \\
\hline Y & 14 & 24 & 18 & 1.171 & 20 & 9 & 41 & 19 & 1.389 & 16 & 18 & 32 & 21 & 1.232 \\
\hline $\mathrm{Zn}$ & 70 & 380 & 130 & 1.616 & 20 & 89 & 3000 & 300 & 2.619 & 16 & 81 & 110 & 94 & 1.097 \\
\hline $\mathrm{Ce}$ & 68 & 100 & 83 & 1.125 & 20 & 25 & 100 & 75 & 1.341 & 16 & 75 & 110 & 92 & 1.147 \\
\hline $\mathrm{Ga}$ & 21 & 30 & 25 & 1.106 & 20 & 10 & 31 & 23 & 1.303 & 16 & 20 & 28 & 24 & 1.134 \\
\hline $\mathrm{La}$ & 36 & 49 & 40 & 1.091 & 20 & 18 & 45 & 36 & 1.214 & 16 & 35 & 49 & 41 & 1.124 \\
\hline Th & 10 & 23 & 14 & 1.248 & 20 & 7 & 25 & 13 & 1.350 & 16 & 12 & 21 & 16 & 1.193 \\
\hline $\mathrm{Yb}$ & $<2$ & 3 & 2 & 1.136 & 19 & $<2$ & 3 & 2 & 1.208 & 14 & 2 & 3 & 2 & 1.242 \\
\hline $\mathrm{Nd}$ & 28 & 50 & 35 & 1.175 & 20 & 17 & 44 & 32 & 1.242 & 16 & 28 & 45 & 40 & 1.169 \\
\hline
\end{tabular}

Note: The minimum and maximum observed concentrations are given as Min. and Max., respectively. The geometric mean and geometric deviation are given as GM and GD, respectively. $N$ is the total number of samples that contained measurable concentrations greater than the lower detection limit for that element or oxide. Dashes under columns for GM and GD indicate that GM and GD were not calculated, because more than $50 \%$ of samples were below the detection limit for that element (indicated by less-than, <, symbol in Min. column).

Table 8. Summary statistics for concentrations of organic carbon (OC), total nitrogen (T-N), and total sulfur (T-S); Rock-Eval pyrolysis hydrogen index ( $\mathrm{HI}$, in mg hydrocarbons/g OC), and oxygen index (OI, in $\mathrm{mg} \mathrm{CO} 2 / \mathrm{g} \mathrm{OC}$ ); and $\delta^{13} \mathrm{C}$ of $\mathrm{OC}$ in parts per thousand relative to the PDB marine carbonate standard in samples of red, green, black claystones from lithologic Unit V, Hole 603B.

\begin{tabular}{|c|c|c|c|c|c|c|c|c|c|c|c|c|c|c|c|}
\hline \multirow[b]{2}{*}{ Parameter } & \multicolumn{5}{|c|}{ Red claystones } & \multicolumn{5}{|c|}{ Green claystones } & \multicolumn{5}{|c|}{ Black claystones } \\
\hline & Min. & Max. & $\bar{x}$ & SD & $N$ & Min. & Max. & $\bar{x}$ & SD & $N$ & Min. & Max. & $\bar{x}$ & SD & $N$ \\
\hline OC-MA (\%) & 0.07 & 0.18 & 0.11 & 0.034 & 8 & 0.08 & 1.14 & 0.34 & 0.26 & 21 & 0.82 & 5.49 & 2.41 & 1.42 & 21 \\
\hline OC-RE $(\%)$ & - & - & - & - & & 0.06 & 0.87 & 0.25 & 0.21 & 14 & 1.29 & 5.48 & 2.84 & 1.35 & 13 \\
\hline T-N $(\%)$ & 0.017 & 0.034 & 0.026 & 0.007 & 8 & 0.012 & 0.051 & 0.029 & 0.011 & 21 & 0.031 & 0.218 & 0.095 & 0.052 & 21 \\
\hline $\mathrm{C} / \mathrm{N}$ & 1.0 & 56 & 12.7 & 19.0 & 8 & 6.6 & 22 & 12 & 9 & 21 & 20 & 30 & 25 & 2.69 & 21 \\
\hline T-S (\%) & 0.01 & 0.15 & 0.04 & 0.05 & 8 & 0.01 & 0.90 & 0.24 & 0.27 & 21 & 0.25 & 3.25 & 1.24 & 0.73 & 21 \\
\hline $\mathrm{HI}$ & - & - & - & - & & 16 & 438 & 189 & 153 & 14 & 17 & 388 & 129 & 97 & 13 \\
\hline $\mathrm{OI}$ & - & - & - & - & & 63 & 500 & 237 & 134 & 14 & 37 & 74 & 49 & 11 & 13 \\
\hline${ }^{{ }^{13} \mathrm{C}}$ & - & - & - & - & & -26.1 & -24.3 & -25.5 & 0.47 & 13 & -27.1 & -24.3 & -26.0 & 0.79 & 13 \\
\hline
\end{tabular}

Note: The minimum and maximum observed concentrations are given as Min. and Max., respectively. The arithmetic mean and standard deviation are given as $\bar{X}$ and SD, respectively. $N$ is the total number of samples analyzed. Dashes indicate no analyses.

bated limestones. More likely, the higher $\mathrm{P}_{2} \mathrm{O}_{5}$ concentrations in the carbonate lithologies are due to phosphorus that was adsorbed on, or incorporated in, the original biogenic carbonate. Froelich et al. (1982) found that the average phosphorus concentration in pelagic calcareous nannofossils is about $440 \mathrm{ppm}$, and suggested that nannofossil ooze is a major sink for phosphorus.

Sulfur in these strata most likely is present mainly in the reduced form. The relatively low concentrations probably indicate that sulfate reduction and iron sulfide for- mation were minor because of the paucity of reactive organic matter in the Neocomian sequences. The generally higher concentrations of suflur, on a carbonate-free basis, in the more OC-rich laminated marlstones probably result from the somewhat better initial preservation of OC in those beds. The sediments probably were not iron-limited.

The pyrolysis results (Figs. 5 and 6), carbon-isotope results (Fig. 7), nitrogen concentrations (Fig. 10), and sulfur and $\mathrm{P}_{2} \mathrm{O}_{5}$ concentrations (Fig. 11) all suggest dif- 
Table 9. Concentrations of $\mathrm{CaCO}_{3}$ and organic carbon (OC); Rock-Eval pyrolysis hydrogen index $(\mathrm{HI}$; in $\mathrm{mg}$ hydrocarbons $/ \mathrm{g} \mathrm{OC}$ ) and oxygen index (OI; in $\left.\mathrm{mg} / \mathrm{CO}_{2} / \mathrm{g} \mathrm{OC}\right) ; \delta^{13} \mathrm{C}$ of $\mathrm{OC}$ in parts per thousand relative to the PDB marine carbonate standard; and Q-mode factor grouping for samples of bioturbated white limestones, transitional laminated marlstones and limestones, and homogeneous black claystones from lithologic Unit V, Hole 603B.

\begin{tabular}{|c|c|c|c|c|c|c|}
\hline $\begin{array}{l}\text { Core-Section, } \\
\text { interval }(\mathrm{cm})\end{array}$ & $\begin{array}{c}\mathrm{CaCO}_{3} \\
(\%)\end{array}$ & $\begin{array}{l}O C \\
(\%)\end{array}$ & HI & OI & $\delta^{13} \mathrm{C}$ & $\begin{array}{l}\text { Q-mode } \\
\text { factor }\end{array}$ \\
\hline \multicolumn{7}{|c|}{ Bioturbated white limestones } \\
\hline $58-4,104$ & 75 & 0.44 & - & - & - & $4 / 3 / 1$ \\
\hline $64-5,43$ & 84 & 0.21 & 2 & 254 & -25.3 & 3 \\
\hline $65-4,100$ & 79 & 0.28 & 0 & 277 & -25.0 & $4 / 3$ \\
\hline $65-4,113$ & 82 & 0.19 & 0 & 232 & -25.2 & 3 \\
\hline $66-3,3$ & 88 & 0.15 & - & - & - & 2 \\
\hline $66-3,25$ & 90 & 0.12 & - & - & - & 3 \\
\hline $66-3,51$ & 78 & 0.20 & - & - & - & 2 \\
\hline $66-3,59$ & 75 & 0.18 & - & - & - & $3 / 1$ \\
\hline $69-3,7$ & 88 & 0.17 & - & - & - & 2 \\
\hline $69-3,19$ & 85 & 0.10 & - & - & - & 2 \\
\hline $69-3,66$ & 88 & 0.13 & - & - & - & 2 \\
\hline $69-3,71$ & 78 & 0.13 & - & - & - & $4 / 3$ \\
\hline $75-2,34$ & 71 & 0.24 & 9 & 225 & -24.8 & $4 / 3$ \\
\hline $75-2,86$ & 70 & 0.47 & 23 & 170 & -24.9 & $1 / 3$ \\
\hline \multicolumn{7}{|c|}{ Laminated marlstones and limestones } \\
\hline $57-1,80$ & 89 & 1.41 & 115 & 81 & -26.7 & 3 \\
\hline $57-1,93$ & 76 & 1.57 & 126 & 79 & -26.5 & 3 \\
\hline $63-5,132$ & 53 & 1.50 & 79 & 85 & -26.5 & $1 / 4 / 3$ \\
\hline $64-5,48$ & 83 & 0.43 & 20 & 184 & -25.6 & 3 \\
\hline $65-1,17$ & 61 & 3.08 & 101 & 79 & -25.7 & $1 / 3 / 4$ \\
\hline $66-3,32$ & 72 & 0.54 & 35 & 122 & -26.0 & $4 / 3 / 1$ \\
\hline $66-3,40$ & 83 & 0.91 & - & - & - & 2 \\
\hline $66-3,44$ & 89 & 0.71 & - & - & - & 2 \\
\hline $69-3,27$ & 85 & 0.14 & - & - & - & 2 \\
\hline $69-3,42$ & 80 & 0.90 & - & - & - & $2 / 4 / 1$ \\
\hline $69-3,48$ & 80 & 0.07 & - & - & - & $2 / 4 / 1$ \\
\hline $69-3,57$ & 78 & 0.23 & - & - & - & 2 \\
\hline $75-2,70$ & 66 & 1.07 & 62 & 90 & -25.5 & $1 / 3$ \\
\hline $75-2,99$ & 56 & 2.05 & 153 & 67 & -25.3 & $1 / 4 / 3$ \\
\hline
\end{tabular}

Homogeneous black claystones

$\begin{array}{lllllll}53-5,28 & 19 & 2.58 & 47 & 60 & -26.7 & 1 \\ 53-5,32 & 14 & 1.70 & 33 & 68 & -25.8 & 1 \\ 57-1,86 & 18 & 2.06 & 25 & 81 & -24.4 & 1 \\ 58-4,102 & 23 & 1.85 & - & - & - & 1 \\ 58-4,106 & 33 & 1.73 & - & - & - & 1 \\ 63-5,128 & 14 & 2.74 & 23 & 55 & -25.3 & 1 \\ 64-5,46 & 19 & 1.61 & 30 & 69 & -25.3 & 1 \\ 65-4,107 & 11 & 1.81 & 25 & 64 & -25.1 & 1 \\ 66-3,35 & 25 & 2.24 & 43 & 53 & -25.7 & 1 \\ 66-3,68 & 15 & 1.53 & - & - & - & 1 \\ 67-4,126 & 19 & 2.45 & 43 & 58 & -25.7 & 1 \\ 69-2,133 & 20 & 1.59 & - & - & - & 1 \\ 69-2,143 & 19 & 1.57 & - & - & - & 1 \\ 75-2,48 & 25 & 1.58 & 37 & 76 & -24.7 & 1 \\ 75-2,61 & 26 & 1.43 & 36 & 65 & -24.8 & 1 \\ 75-2,114 & 15 & 1.70 & 41 & 59 & -24.5 & 1\end{array}$

Note: Dashes (-) indicate no analyses for that parameter for that sample.

ferences in the sources and degree of preservation of organic matter in the Neocomian carbonates in the eastern and western basins of the North Atlantic during the Early Cretaceous. The bioturbated white limestones at Site 603 probably contain a background hemipelagic "rain" of organic matter, consisting of a mixture of terrestrial and highly degraded marine organic matter. This is indicated by their low HI and higher OI values (Figs. 5 and 6 ), and values of $\delta^{13} \mathrm{C}$ that are not as light as those of the more marine Neocomian OC-rich strata at Site 367 off Northwest Africa (Fig. 7). The only significant amounts of marine organic matter in the Site 603 samples from lithologic Unit V are preserved in the laminated marlstones and limestones, as indicated by higher values of $\mathrm{HI}$ and higher concentrations of OC (Figs. 5 and 6), and possibly by higher concentrations of sulfur (Fig. 11). Even in the laminated carbonate beds, the organic matter is highly degraded and mixed with terrestrial organic matter, as indicated by lower $\mathrm{HI}$ and higher OI values relative to other strata rich in marine OC, such as those of equivalent age at Site 367 (Fig. 5). The bioturbated white limestones at Site 367 also contain mixed terrestrial and marine organic matter with a larger proportion of marine organic matter than their equivalent lithology at Site 603 (indicated by lighter values of $\delta^{13} \mathrm{C}$ and higher HI values; Figs. 5 and 7). This organic matter also has been highly degraded (indicated by the high OI values; Fig. 5). The organic matter in the laminated black marlstones at Site 367 and homogeneous black claystones at Site 603 is most likely redeposited material from shallower sites of accumulation. This is indicated by the sharp basal contacts, homogeneous texture, and association with sand and silt beds at Site 603 (see Site 603 chapter, this volume). At Site 603, this organic matter is largely terrestrial, as indicated by low $\mathrm{HI}$ values (Fig. 5), heavy $\delta^{13} \mathrm{C}$ values (Fig. 7), very low concentrations of nitrogen and high $\mathrm{C} / \mathrm{N}$ ratios (Fig. 10), and low concentrations of sulfur and $\mathrm{P}_{2} \mathrm{O}_{5}$ (Fig. 11). This organic matter probably was derived from the same coastal wetlands of North America that produced extensive Cretaceous coal deposits (e.g., Parrish et al., 1982; Beeson, 1984). At Site 367 , this organic matter is largely marine, derived from accumulations of phytoplankton debris in highly productive shelf and slope environments under strong upwelling conditions that existed along the coast of Northwest Africa in the Cretaceous just as they do today (Arthur and Natland, 1979; Tissot et al., 1980; Parrish and Curtis, 1982; Barron, 1985).

Many other studies indicate that, in general, the supply of organic matter to the western basin of the North Atlantic throughout most of the Cretaceous was mainly terrestrial, along with some highly degraded marine organic matter (e.g., Tissot et al., 1979, 1980; Summerhayes 1981, 1986; Herbin and Deroo, 1982; de Graciansky et al., 1982; Habib, 1983). Previous studies also indicate that much of this organic matter may have been redeposited by turbidity currents from shallower environments (e.g., Habib, 1979, 1983; Dean and Gardner, 1982; Summerhayes and Masran, 1983, Arthur, Dean, and Stow, 1984). Most of organic matter in Cretaceous OC-rich strata in the eastern North Atlantic appears to have a similar origin, except in the region off central Northwest Africa, particularly in the Cape Verde Basin and Rise (Sites 367 and 368), where the organic matter was derived mainly from autochthonous marine sources throughout the Cretaceous (e.g., Tissot et al., 1979, 1980; Summerhayes, 1981; Herbin and Deroo, 1982; de Graciansky et al., 1982). The organic geochemical results already presented here substantiate these previous studies. We suggest that the organic matter in the black li- 


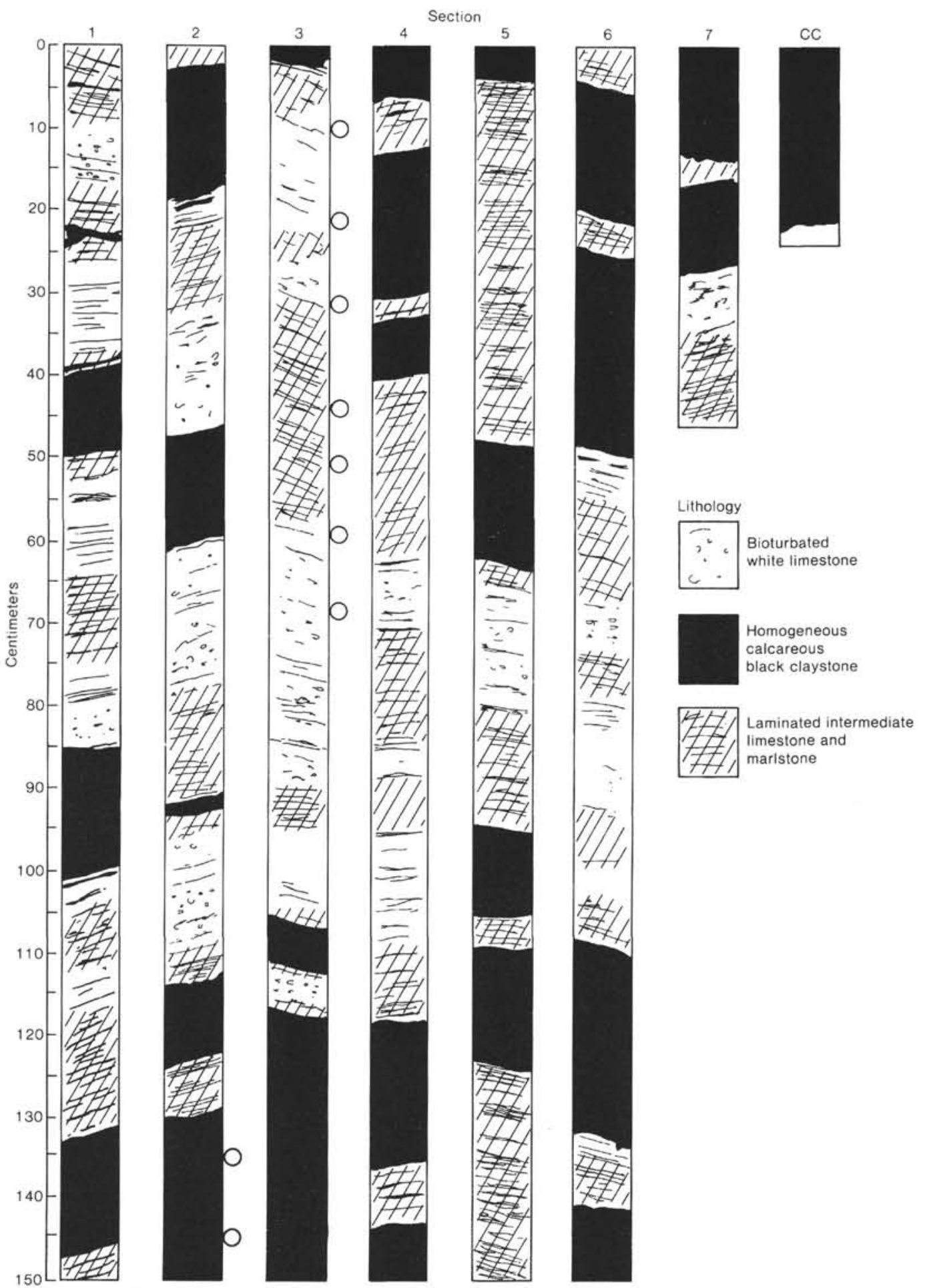

Figure 3. Diagrammatic representation of the three Neocomian lithologic types as they occur in Core 69, Hole 603B. Circles mark the locations of samples collected for this investigation.

thologies at these two sites (603 and 367) represents two different end-member sources for organic matter in Cretaceous proto-Atlantic Ocean.

The origin of the laminations in the transitional marlstones and limestones at Site 603 is still somewhat puzzling. The association of the laminations with betterpreserved organic matter suggests that they may have resulted from lack of bioturbation in oxygen-depleted bottom-waters. And yet the laminations are not as thin as might be expected for deposition under anoxic bottom waters. We suggest that the lamination is currentinduced, and that the laminated-bioturbated cycles are due to fluctuations in bottom-current intensity. The laminated intervals therefore contain reworked terrigenous 


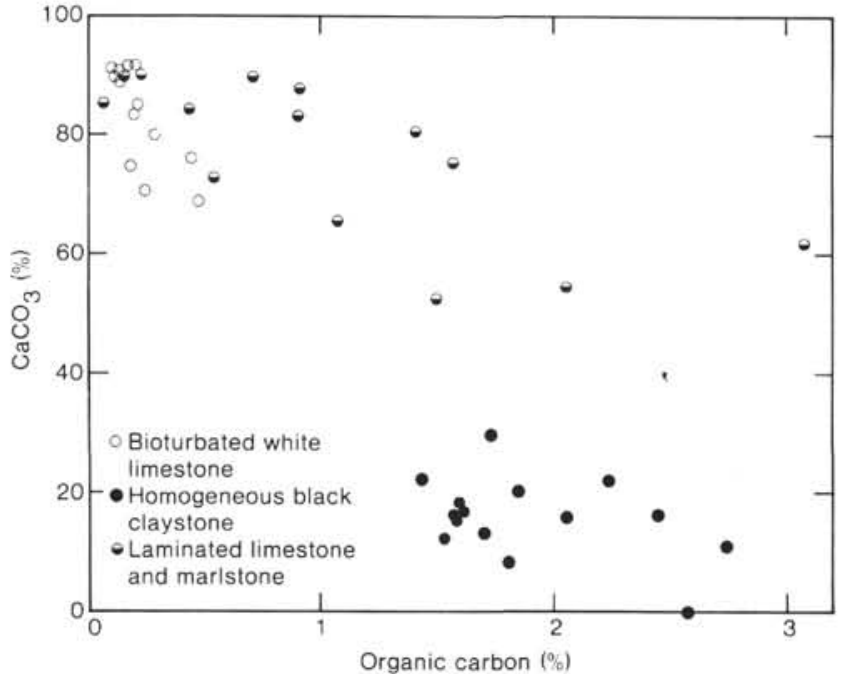

Figure 4. Plot of percent organic carbon (whole-rock basis) versus percent $\mathrm{CaCO}_{3}$ (measured at Univ. of Rhode Island) for the three Neocomian lithologic types of Hole 603B.

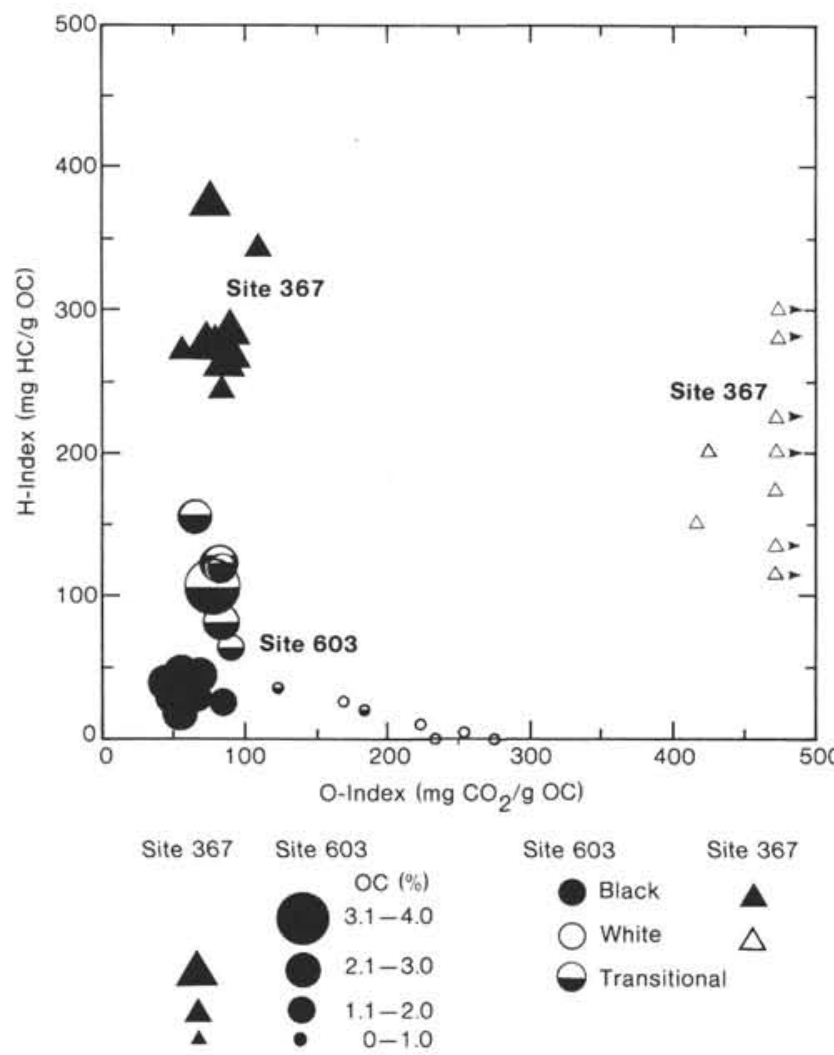

Figure 5. Plot of Rock-Eval hydrogen index versus oxygen index for samples of Neocomian carbonates from Sites 367 and 603 .

detritus mixed with normal pelagic material, and probably were deposited at somewhat higher rates than the bioturbated limestones. Such an origin would explain the higher concentrations and better preservation of organic matter in the laminated beds, because higher sedimentation rates tend to enhance the preservation of organic matter (e.g., Muller and Suess, 1979). Jansa et al. (1979) concluded that the laminated Neocomian carbon-

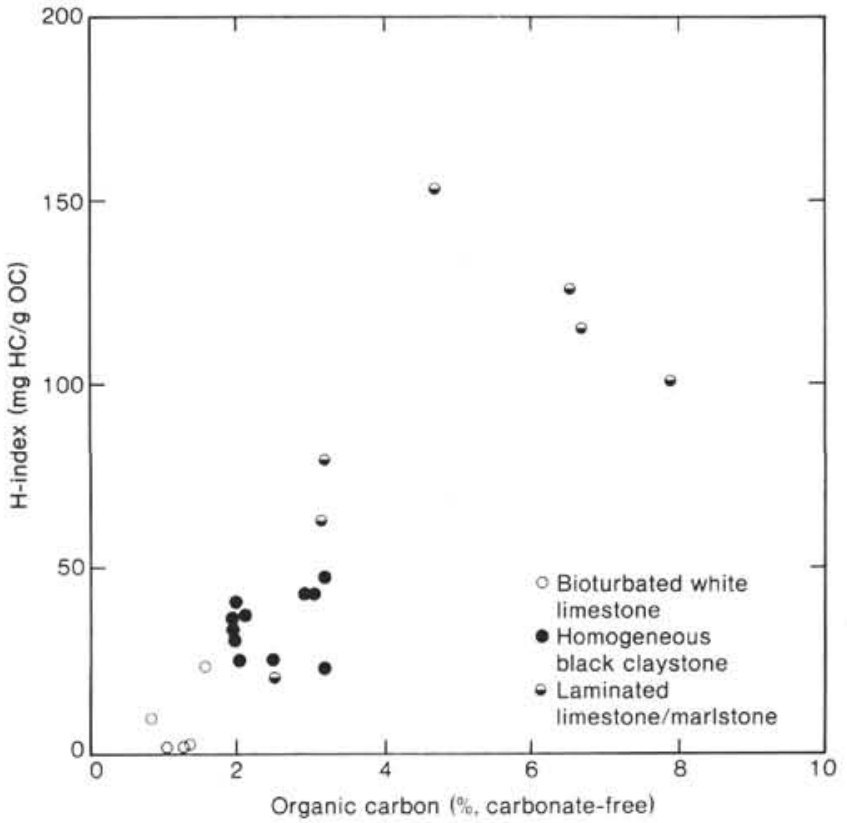

Figure 6. Plot of percent carbonate-free organic carbon versus RockEval hydrogen index for samples of the three Neocomian lithologic types of Hole 603B. See Figure 4 for symbol designations.

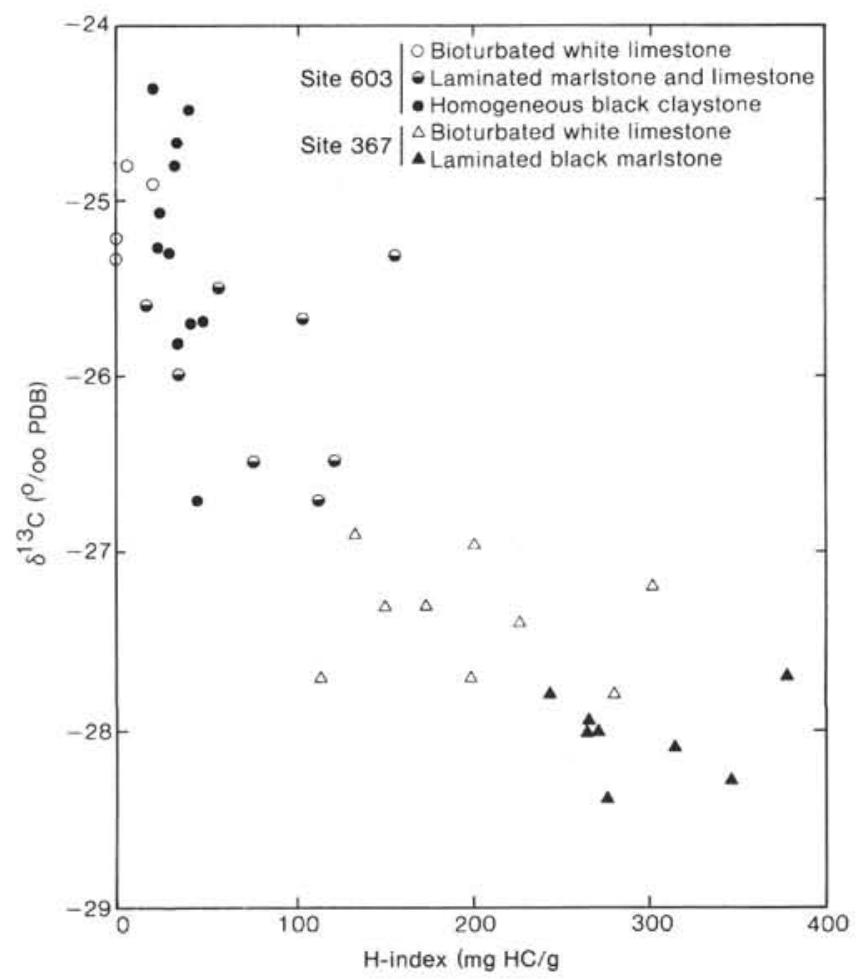

Figure 7. Plot of Rock-Eval hydrogen index versus $\delta^{13} \mathrm{C}$ of organic matter in samples of Neocomian carbonates from Site 367 in the eastern North Atlantic and Site 603 in the western Atlantic.

ates at Site 391 in the North American Basin may include fine-grained turbidites derived from the Blake Plateau, and that some of the laminations may be due to reworking by bottom currents that were intensified near the steep escarpment of the plateau. The graded coarse 
cost B-2

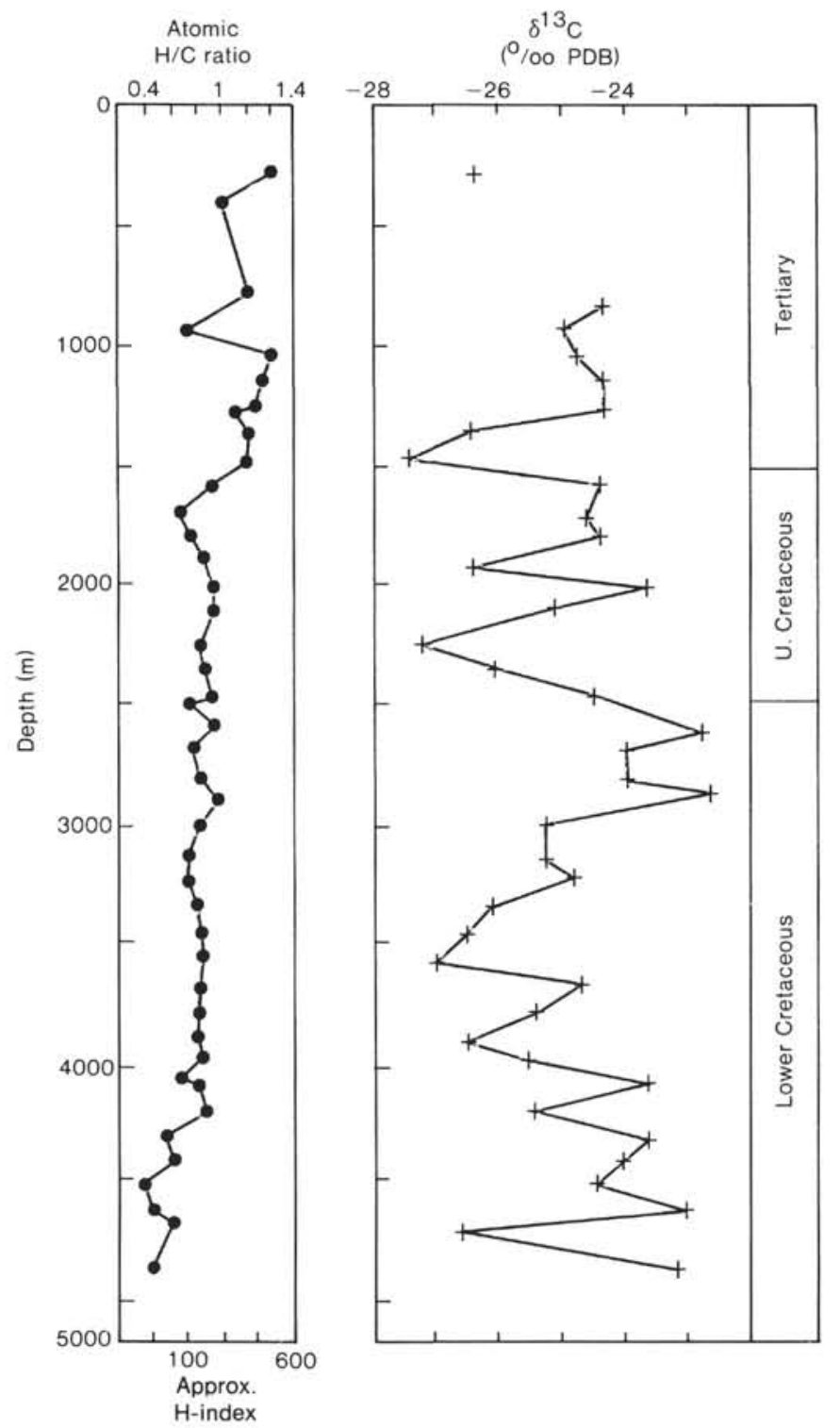

cost B-3

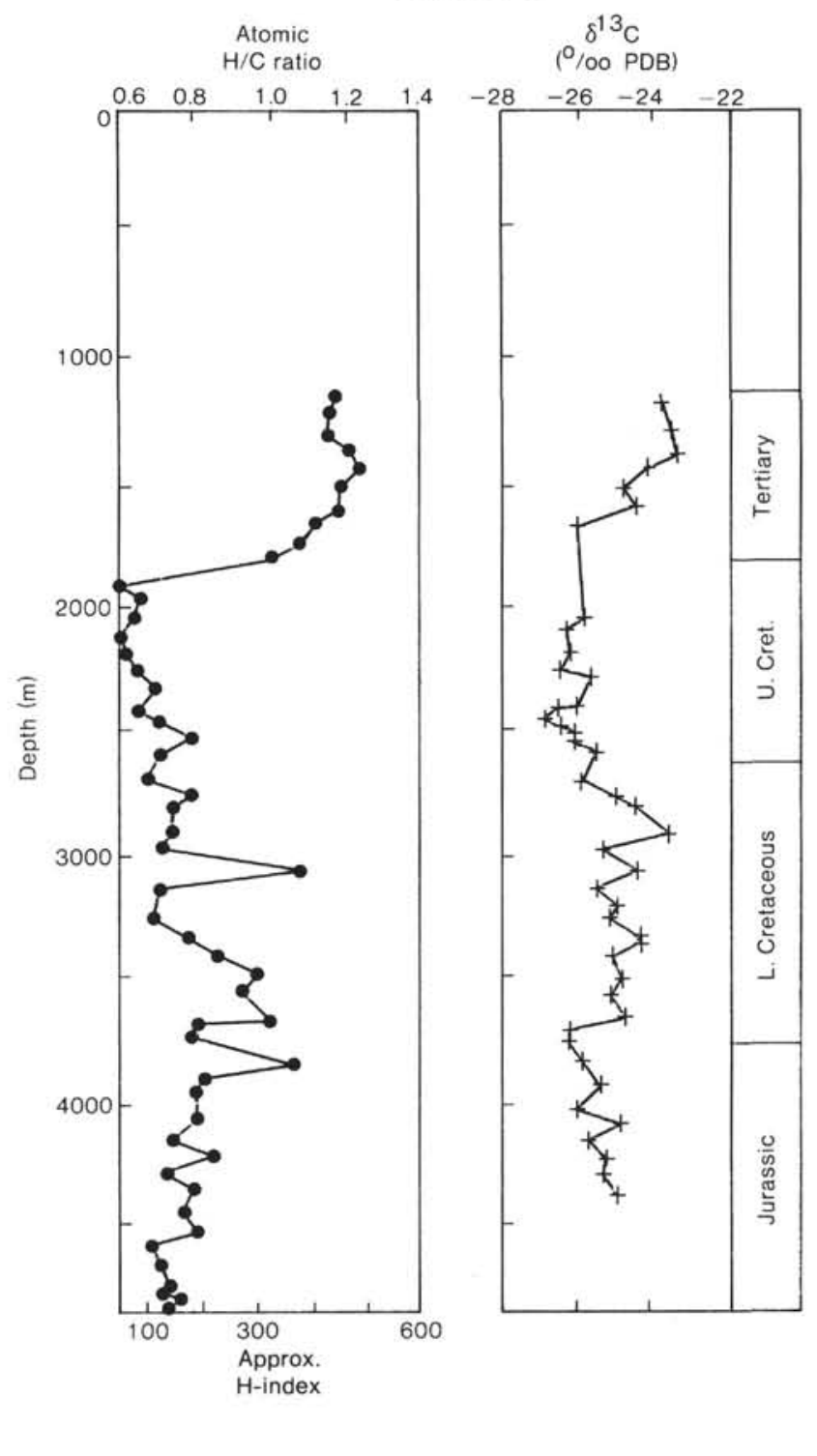

Figure 8. Downhole plots of atomic H/C ratio and $\delta^{13} \mathrm{C}$ of organic carbon for Continental Offshore Stratigraphic Test (COST) wells B-2, B-3, G-2, and GE-1. See Figure 1 for locations of wells.

clastics within lithologic Unit $\mathrm{V}$ certainly indicate that turbidity-current deposition was important at Site 603 . Tucholke and Mountain (1979) noted thickness variations in seismic reflection profiles of the Neocomian carbonates along the continental margin of North America, and attributed them to structures induced by contour currents. We believe that the high sedimentation rates, the sedimentary structures, and the content and preservation of organic matter are all consonant with a current-induced origin of the laminations. The inorganic geochemical results discussed in the next section lend further support to this hypothesis.

\section{Inorganic Geochemistry}

Figure $12 \mathrm{~A}$ shows the ranges and arithmetic mean concentrations of organic carbon, total sulfur, and total nitrogen, and the ranges and geometric mean concentra- tions of major- and minor-element oxides (in percent) on a carbonate-free basis, in samples of the three lithologic types at Site 603 and the two lithologic types at Site 367. Figure 12B shows the carbonate-free concentrations (in parts per million, ppm) of trace elements in the same samples. The most distinctive geochemical features are (1) the higher concentrations of organic carbon, sulfur, nitrogen, and $\mathrm{P}_{2} \mathrm{O}_{5}$ in the laminated carbonate beds at Site 603 , relative to the other two lithologic types, particularly the black claystones: (2) higher concentrations of $\mathrm{Al}_{2} \mathrm{O}_{3}, \mathrm{~K}_{2} \mathrm{O}$, and $\mathrm{TiO}_{2}$ in the black lithologies at both sites; (3) markedly lower concentrations of $\mathrm{MnO}$ and slightly lower concentrations of $\mathrm{MgO}$ and $\mathrm{Fe}_{2} \mathrm{O}_{3}$ in black claystones at Site 603; (4) lower concentrations of most trace elements, especially $\mathrm{Cu}, \mathrm{Cr}$, $\mathrm{Ni}, \mathrm{Co}$, and $\mathrm{Pb}$, in black claystones from Site 603, and higher concentrations of $\mathrm{V}, \mathrm{Cu}$, and $\mathrm{Ni}$ in black marl- 
cosT G-2

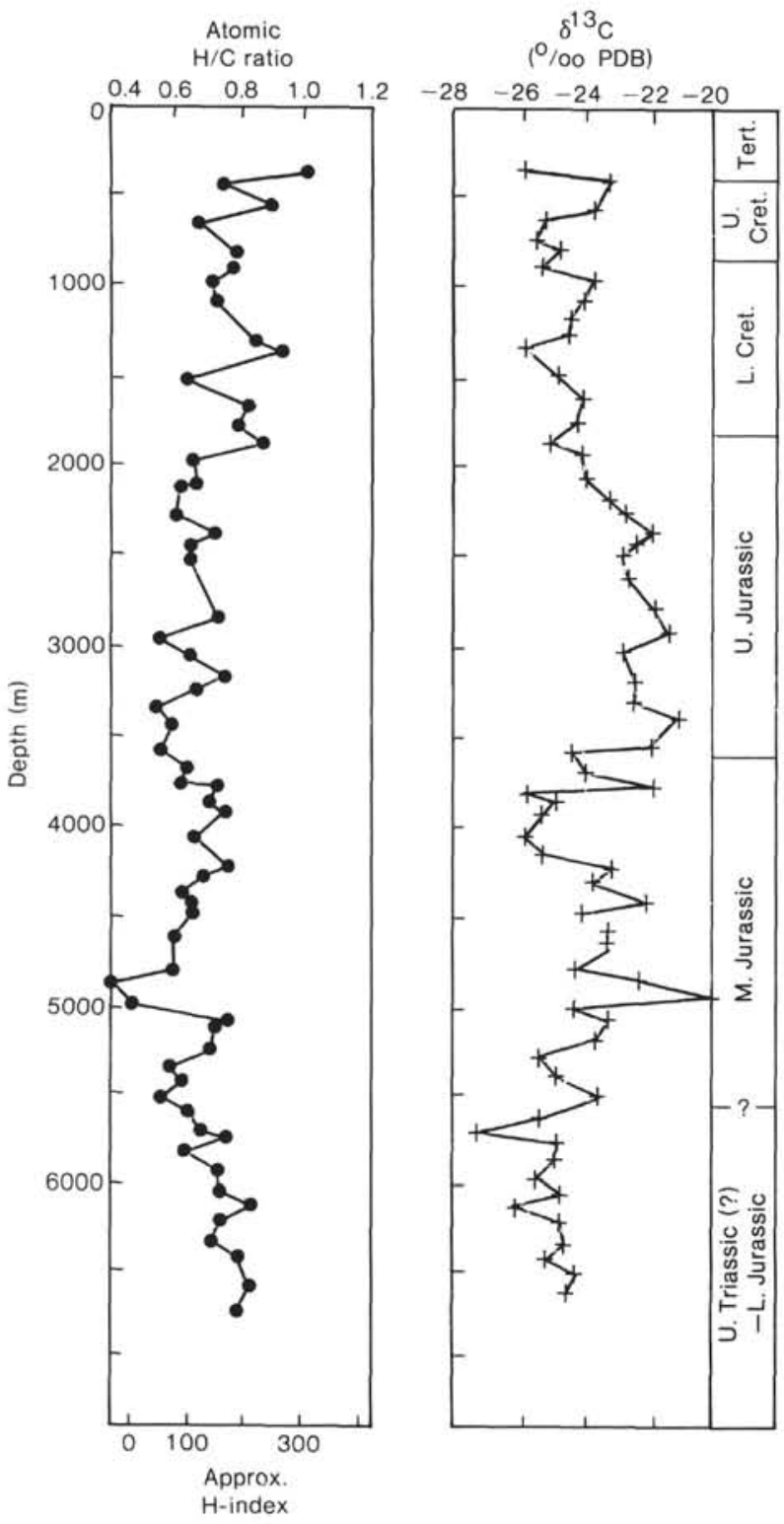

COST GE-1

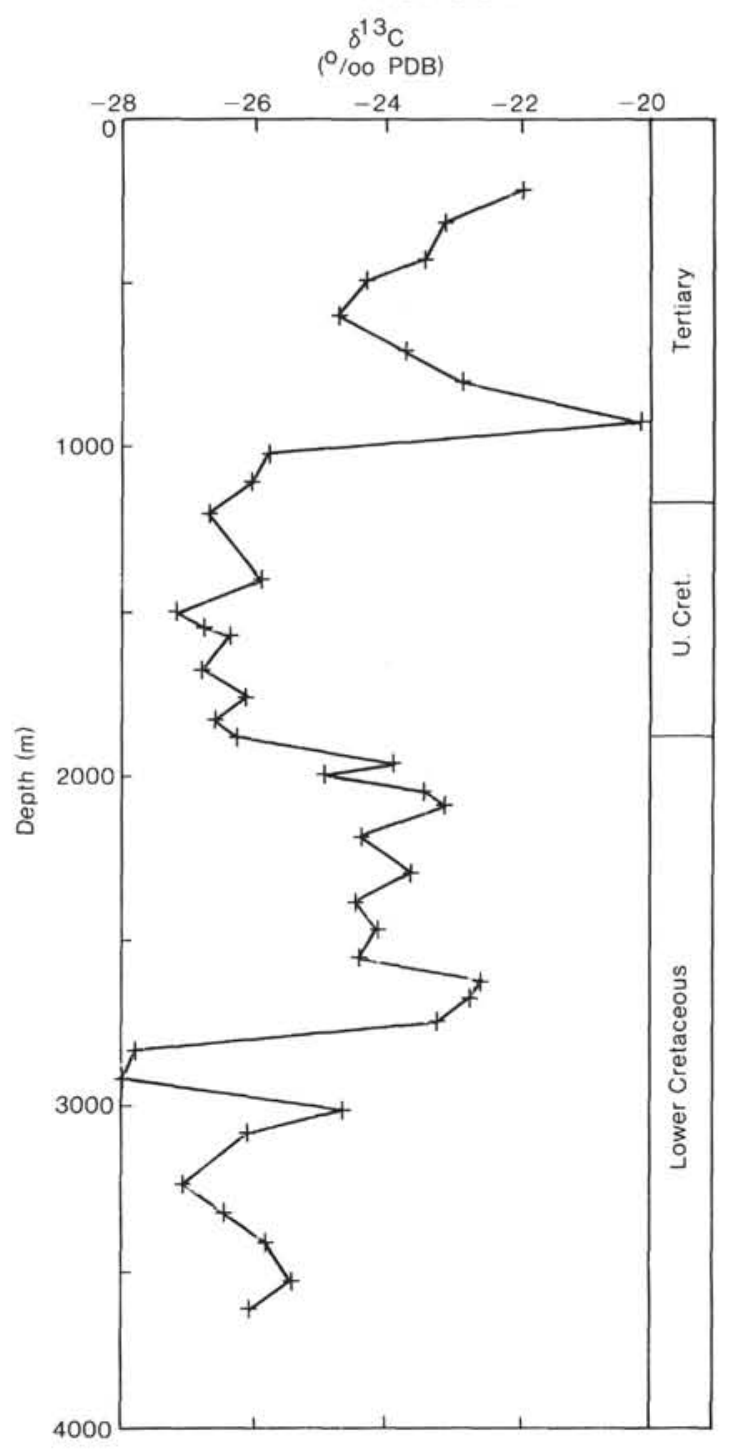

Figure 8 (continued).

stones from Site 367; and (5) Higher concentrations of most trace elements in the transitional laminated limestones and marlstones, relative to both the black claystones and the bioturbated white limestones at Site 603 .

There appears to be a distinct compositional difference between the detrital-clastic (noncarbonate) component in the black claystones and that in the laminated and bioturbated carbonate lithologies (Fig. 12A). This is indicated by the markedly higher carbonate-free concentrations of $\mathrm{Al}_{2} \mathrm{O}_{3}, \mathrm{~K}_{2} \mathrm{O}$, and $\mathrm{TiO}_{2}$. These differences in composition of clastic fractions between lithologic types are clearer in Figure 13, a plot of $\mathrm{Al}_{2} \mathrm{O}_{3} / \mathrm{TiO}_{2}$ ratio versus $\mathrm{Na}_{2} \mathrm{O} / \mathrm{K}_{2} \mathrm{O}$ ratio for the Neocomian samples from Hole 603B; average values from mid-Cretaceous claystones of lithologic Unit IV are provided for comparison. The Neocomian black claystones have ratios distinctly different from those of bioturbated limestone beds and essentially identical to those of the black claystones of Unit IV. The laminated carbonate beds overlap both of the other lithologic types in terms of $\mathrm{Al}_{2} \mathrm{O}_{3} / \mathrm{TiO}_{2}$ ratio, but are closer to the bioturbated limestones in terms of $\mathrm{Na}_{2} \mathrm{O} / \mathrm{K}_{2} \mathrm{O}$ ratio. On the basis of Figure 13, we consider $\mathrm{Al}_{2} \mathrm{O}_{3}$ ratios of 20 to 25 and $\mathrm{Na}_{2} \mathrm{O} / \mathrm{K}_{2} \mathrm{O}$ ratios of 0.3 to 0.6 to be typical of terrigenous clastics derived from the eastern margin of North America during the Early Cretaceous. The black marlstones at Site 367 also have low $\mathrm{Al}_{2} \mathrm{O}_{3} / \mathrm{TiO}_{2}$ and $\mathrm{Na}_{2} \mathrm{O} / \mathrm{K}_{2} \mathrm{O}$ ratios (Dean and Gardner, 1982; Arthur and Dean, unpublished data), similar to those of the black claystones at Site 603. The bioturbated white limestones at Site 367 , like the carbonate-rich lithologies at Site 603 , have high $\mathrm{Al}_{2} \mathrm{O}_{3} / \mathrm{TiO}_{2}$ ratios (range of 28-62, mean of 41; Arthur and Dean, unpublished data) and particularly high $\mathrm{Na}_{2} \mathrm{O} / \mathrm{K}_{2} \mathrm{O}$ ratios (range of 2.7-6.5, mean of 4.6). The trends of the two 


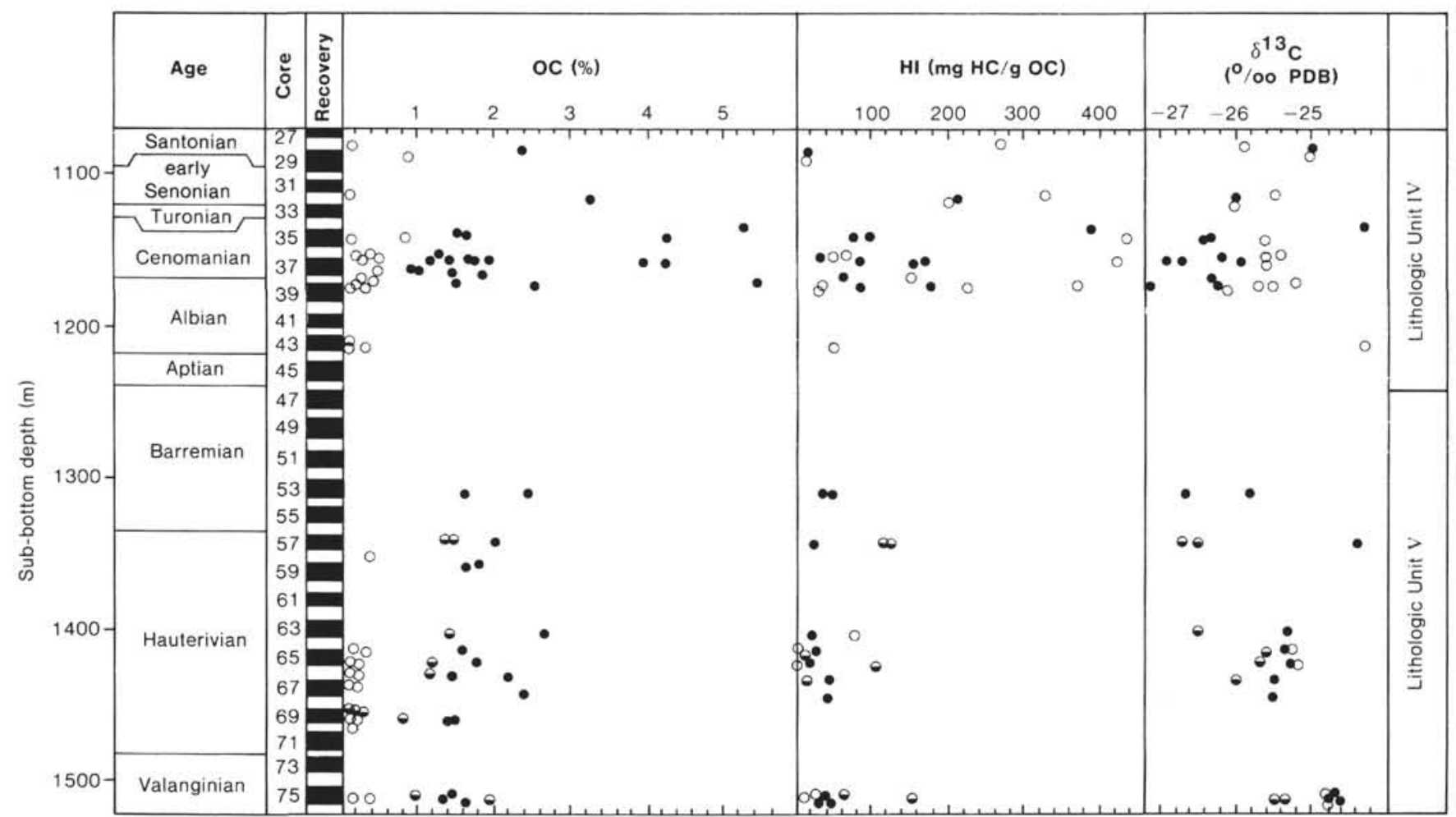

Figure 9. Stratigraphic variations in percent organic carbon (whole-rock basis), Rock-Eval hydrogen index, and $\delta^{13} \mathrm{C}$ for Neocomian carbonates and mid-Cretaceous green and black claystones recovered from Hole 603B. Symbol designations for lithologic Unit V lithologies are the same as in Figure 4. For lithologic Unit IV, samples of green claystone are indicated by open circles and samples of black claystone are indicated by closed circles.

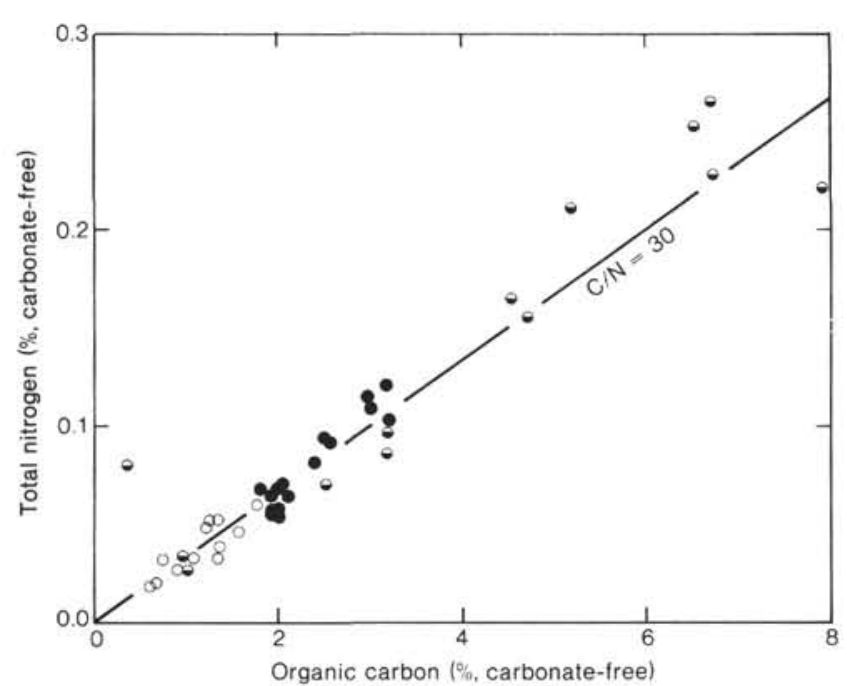

Figure 10. Plot of percent organic carbon versus percent total nitrogen on a carbonate-free basis for the three Neocomian lithologic types of Hole 603B. Symbol designations are the same as in Figure 4.

ratios in the carbonate lithologies at Site 603 toward values similar to those in the white limestones at Site 367 may indicate a mixing of North American and African clastic sources in these pelagic carbonates. Alternatively, the compositional differences between the two sites may result from regional climatic differences, such as more arid conditions in Northwest Africa and more hu-

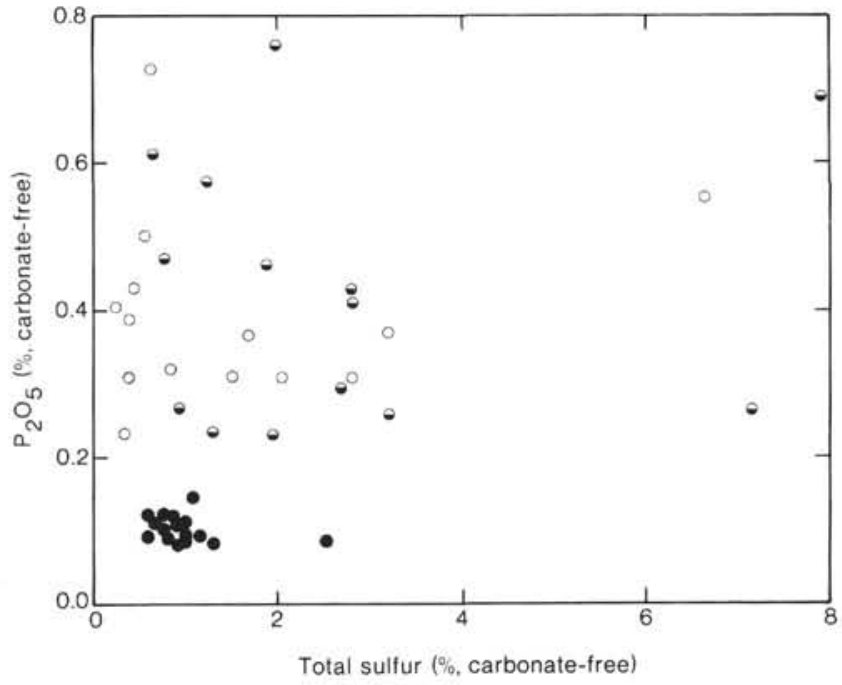

Figure 11. Plot of percent total sulfur versus percent $\mathrm{P}_{2} \mathrm{O}_{5}$ on a carbonate-free basis for the three Neocomian lithologic types of Hole 603B. Symbol designations are the same as in Figure 4.

mid conditions in eastern North America (e.g., Parrish et al., 1982; Barron and Washington, 1982; Hallam, 1985).

We do not have mineralogical data for samples from Site 603 that might help explain the geochemical data, but reconnaissance mineralogical studies of Jurassic to Pleistocene samples from other Atlantic DSDP sites do 
A

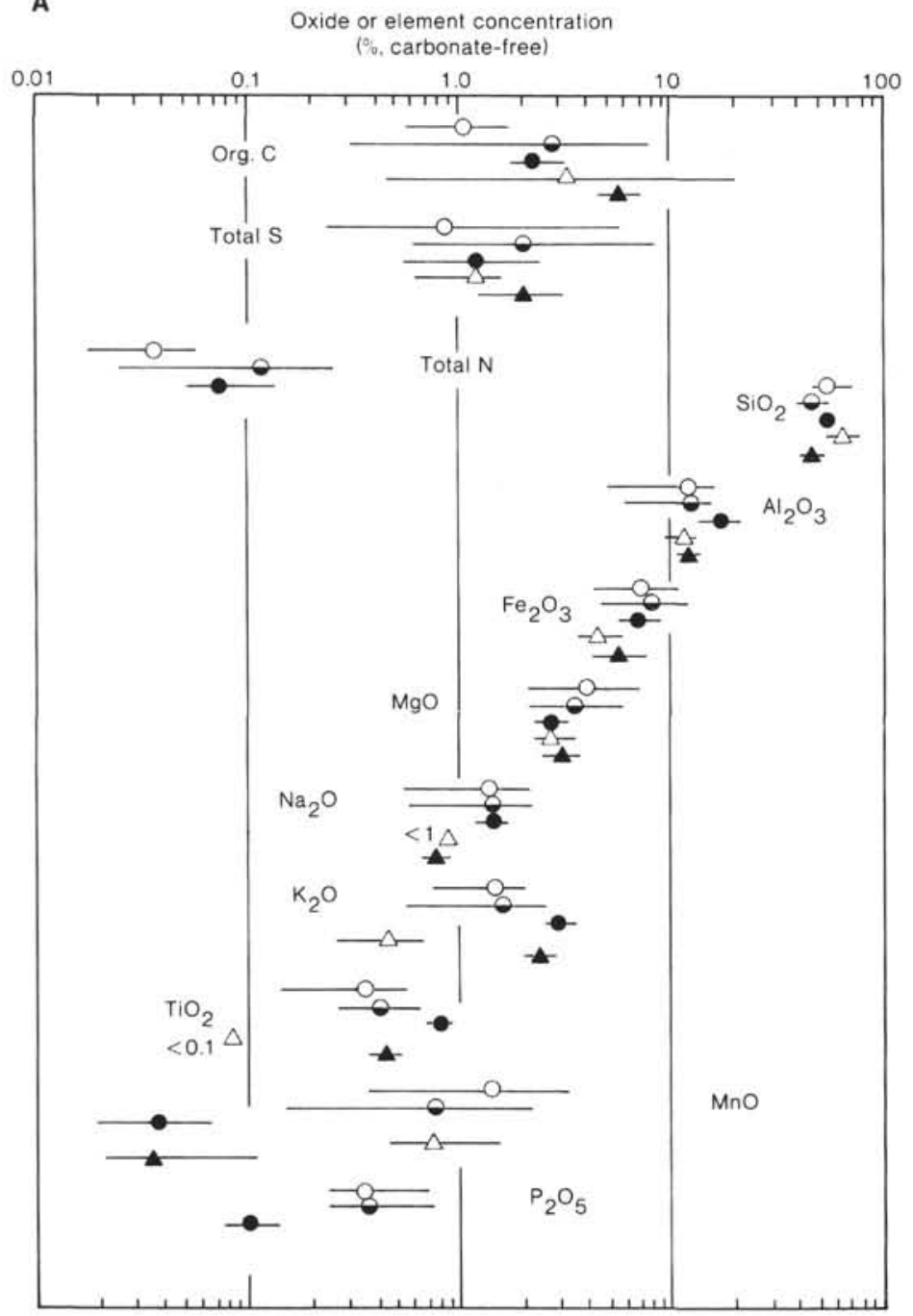

B

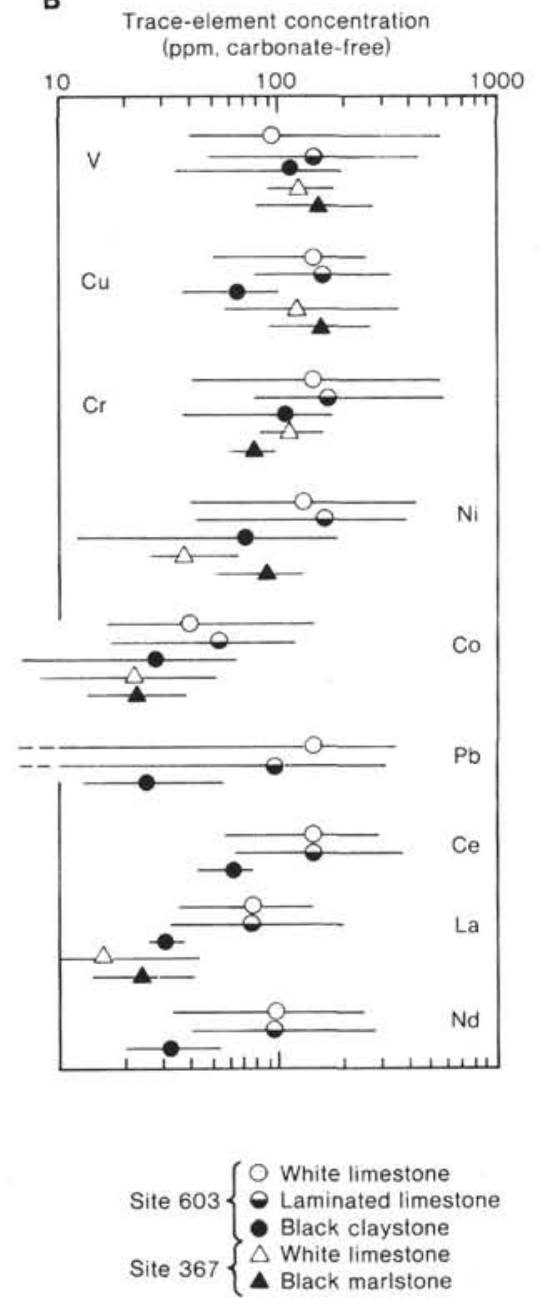

Figure 12. Comparison of concentrations of (A) major elements and oxides and (B) trace elements, on a carbonate-free basis, in samples of Neocomian carbonates from Site 367 in the eastern North Atlantic and Site 603 in the western North Atlantic. Bars indicate the total observed ranges of element concentration; symbols are plotted at the geometric mean concentration for each element or oxide (Table 5).

provide some information (e.g., Chamley, 1979; Chamley and Debrabant, 1984a, b; Chamley et al., 1979, 1983; Debrabant and Chamley, 1982, Debrabant et al., 1984). These studies have established that smectite is the dominant clay mineral in the clastic fraction of the Neocomian carbonates in the eastern and western basins of the North Atlantic, as well as in the Gulf of Mexico. Of particular significance is the low abundance of kaolinite a common clay mineral in many continental and shallow-water sequences of the same age. Chamley and Debrabant $(1984 a, b)$ ascribed these differences to preferential entrapment of kaolinite relative to smectite in marginal basins. Abundant illite was found only at Site 416 off Northwest Africa and Site 387 in the western North Atlantic. The abundance of illite (as well as mixed-layer clays and kaolinite) off Northwest Africa (Site 416) may reflect the uplift of the Atlas Mountains, beginning in the Jurassic. The abundance of illite at Site 387 and its low abundance at every other site in the western North Atlantic is difficult to explain. Chamley and Debrabant (1984a, b) suggested that the clastic fraction of the Neocomian carbonates at Site 387 was derived from an eastern North Atlantic source and transported by bottom currents. The low $\mathrm{Na}_{2} \mathrm{O} / \mathrm{K}_{2} \mathrm{O}$ ratio of the Neocomian black marlstones at Site 367 also may be due to increase in the supply of illite to this site during wetter conditions that also resulted in greater decomposition of $\mathrm{Na}$ feldspars in the source clastic debris.

The clastic component of the black claystones of lithologic Unit V of Hole 603B can readily be distinguished from that of the carbonate lithologies on the basis of carbonate-free concentrations of several of the major-element oxides and their ratios, but these oxides do not separate the two carbonates lithologic types (laminated and bioturbated) as well as do some of the characteristics of the organic matter (e.g., OC, HI, and OI; Figs. 5 and 6). Figure 12B shows that there are also some fairly large differences between lithologic types based on carbonate-free concentrations of minor and trace elements, especially $\mathrm{Mn}, \mathrm{Pb}$, and some of the other transition ele- 


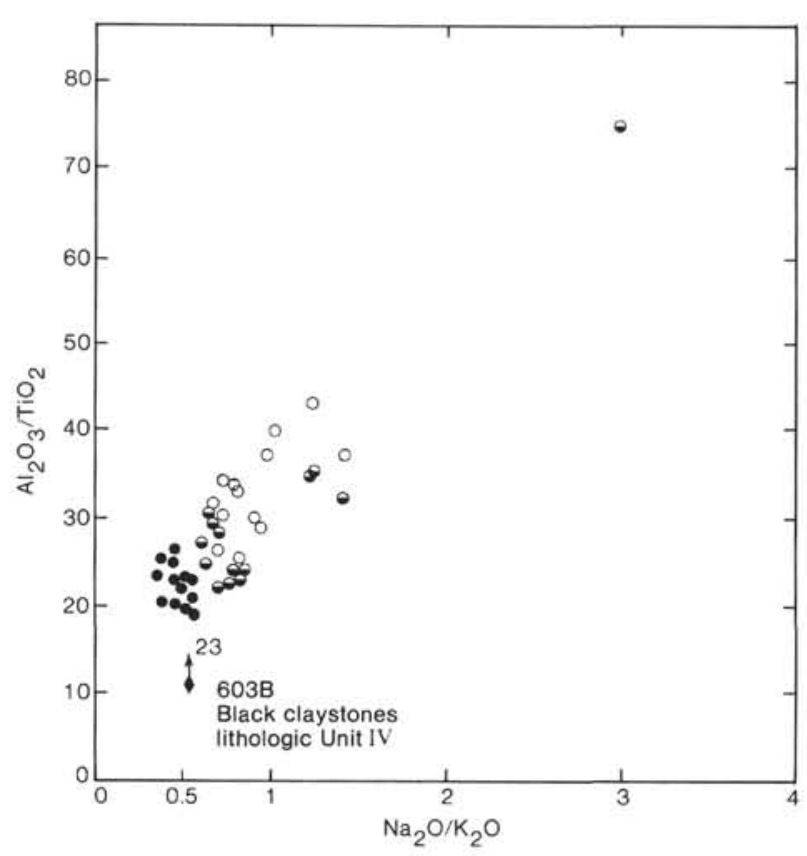

Figure 13. Plot of $\mathrm{Al}_{2} \mathrm{O}_{3} / \mathrm{TiO}_{2}$ ratio versus $\mathrm{Na}_{2} \mathrm{O} / \mathrm{K}_{2} \mathrm{O}$ ratio for the three Neocomian lithologic types of Hole 603B. Also shown is the average value of the ratios in claystones of lithologic Unit IV, Hole $603 \mathrm{~B}$ - this value is 23 , indicated by the arrow (if this point were plotted, it would be buried by other data). Symbol designations are the same as in Figure 4.

ments such as $\mathrm{Cu}, \mathrm{Cr}, \mathrm{Ni}$, and $\mathrm{Co}$. Plots of the concentrations of individual elements against one another show some separation of lithologic types, but again the separation is not so distinctive as that produced by the organic characteristics. Two such plots, $\mathrm{MnO}$ versus $\mathrm{Pb}$ and $\mathrm{Ni}$ versus $\mathrm{Co}$, are shown as examples in Figure 14. The plot of $\mathrm{MnO}$ versus $\mathrm{Pb}$ (Fig. 14A) shows two distinct trends, each with a positive correlation between $\mathrm{MnO}$ and $\mathrm{Pb}$ but with different slopes. These two trends may reflect subtle differences in source, carbonate diagenesis, or redox condition. The plot of Ni versus Co (Fig. 14B) shows a strong positive correlation between these two elements, and in fact most of the trace transition elements are correlated among each other.

Minor- and trace-element concentrations generally are similar between Sites 603 and 367, even though there appears to be a distinct difference in the predominant source of organic matter at the two sites. Concentrations of V, $\mathrm{Cu}$, and $\mathrm{Ni}$ tend to be somewhat higher in the black marlstones from Site 367, which contain more marine organic matter, but the only significant differences are in mean concentrations of $\mathrm{Cu}$ between black marlstones at Site 603 and those at Site 367, and in mean concentrations of $\mathrm{Ni}$ between white limestones and black marlstones at Site 367. The much higher concentrations of $\mathrm{MnO}$ in white limestones at both sites, relative to the black marlstones, probably result from substitution of reduced $\mathrm{Mn}$ for $\mathrm{Ca}$ in $\mathrm{CaCO}_{3}$ during early diagenetic cementation.

\section{Q-Mode Factor Analysis}

To define the differences between lithologic types more objectively on the basis of the inorganic geochemical re-
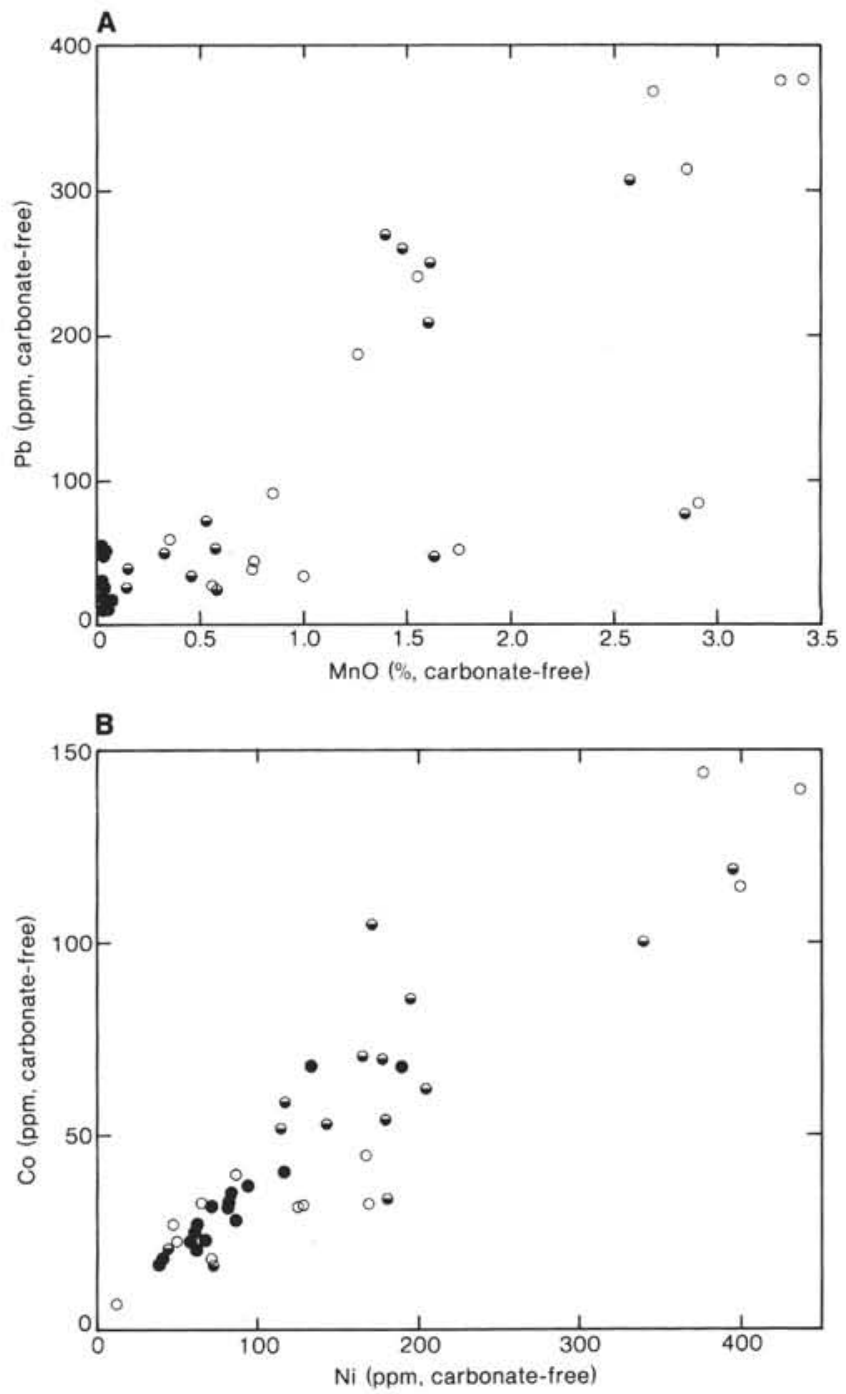

Figure 14. Plots of (A) percent $\mathrm{MnO}$ versus ppm $\mathrm{Pb}$ and (B) ppm Ni versus ppm $\mathrm{Co}$, all on a carbonate-free basis, in the three Neocomian lithologic types from Hole 603B. Symbol designations are the same as in Figure 4.

sults, we did a Q-mode factor analysis of all the Neocomian samples, using the extended CABFAC program described by Klovan and Miesch (1976). Prior to the analysis, we transformed concentrations of all oxides and elements to proportions of the total range for each oxide or element. As a result of the transformation, all data were expressed on a scale of 0.0 to 1.0 . This transformation prevents the variance of one or two elements that are present in large concentrations and that have large variances from dominating the results of the factor analysis. After trying several different sets of reference axes in multidimensional space, we ultimately chose four orthogonal reference axes that maximize the evidence of the transformed data in each of the four dimensions (varimax solution). This four-factor varimax solution explained $92 \%$ of the variance in the transformed data. In the fourfactor varimax model, the 22 observed compositional variables for each sample are reduced to four composite compositional variables (factor loadings), that are expressed on a scale of -1.0 to 1.0. Each factor expresses 
some compositional attribute of the rocks based on this synthesis of several measured compositional variables (elements). To determine which elements had the largest variance contributions to the composite compositional variables (factor loadings), the factor loadings were treated as composite chemical variables, and correlation coefficients were computed between the loadings and the 22 observed compositional variables (elements and oxides). Results of this correlation analysis are given in Table 10.

The grouping of individual samples of Neocomian carbonates into one or more of the four Q-mode factors is compared with our subjective grouping into the three lithologic types in Table 9. The Q-mode classification is entirely compatible with our lithologic classification, and aids in identifying the most important geochemical characteristics of each of the lithologic types. Factor 1 loadings correlate most highly with concentrations of $\mathrm{Ti}, \mathrm{K}$, and $\mathrm{Al}$ (Table 10), and samples with high loadings for factor 1 are all homogeneous black claystones. We therefore interpret factor 1 as a composite "detrital clastic" chemical end member that characteristically has high concentrations of $\mathrm{Al}, \mathrm{K}$, and $\mathrm{Ti}$, and is most important in the black claystones.

Factor 2 loadings correlate most highly with carbonate-free concentrations of $\mathrm{Pb}$ and $\mathrm{Mn}$, and less highly with concentrations of $\mathrm{P}_{2} \mathrm{O}_{5}$ and total S (Table 10). The basis for the factor 2 grouping is clear in the plots of carbonate-free concentrations of sulfur versus $\mathrm{P}_{2} \mathrm{O}_{5}$ (Fig. 11) and $\mathrm{MnO}$ versus $\mathrm{Pb}$ (Fig. 14A). That the samples with high loadings for factor 2 are mostly bioturbated white limestones and some laminated limestones (Table 9) suggests that $\mathrm{Pb}, \mathrm{Mn}$, and to a lesser extent $\mathrm{P}$ and $\mathrm{S}$

Table 10. Correlation coefficients for Q-mode factor loadings (factors 1-4) versus carbonate-free concentrations of major-element oxides and trace elements in Neocomian carbonate samples from lithologic Unit V, Hole 603B; variance and cumulative variance of the transformed data explained by each factor of the 4-factor model also are given.

\begin{tabular}{lrrrr}
\hline $\begin{array}{l}\text { Element } \\
\text { or oxide }\end{array}$ & Factor 1 & Factor 2 & Factor 3 & Factor 4 \\
\hline $\mathrm{Al}_{2} \mathrm{O}_{3}$ & 0.7959 & -0.8961 & 0.0056 & -0.0854 \\
$\mathrm{Fe}_{2} \mathrm{O}_{3}$ & -0.2852 & -0.0517 & 0.6612 & 0.1642 \\
$\mathrm{MgO}^{2}$ & -0.4849 & 0.0868 & 0.8578 & -0.0957 \\
$\mathrm{Na}_{2} \mathrm{O}$ & 0.1226 & -0.3335 & 0.4138 & 0.3400 \\
$\mathrm{~K}_{2} \mathrm{O}$ & 0.9231 & -0.6799 & -0.5998 & 0.0223 \\
$\mathrm{TiO}_{2}$ & 0.9655 & -0.8008 & -0.4959 & -0.0600 \\
$\mathrm{P}_{2} \mathrm{O}_{5}$ & -0.7783 & 0.5474 & 0.6114 & 0.1629 \\
$\mathrm{MnO}$ & -0.7975 & 0.8215 & 0.2928 & -0.2401 \\
$\mathrm{Co}$ & -0.2118 & -0.1483 & 0.4412 & 0.8320 \\
$\mathrm{Cr}$ & -0.3200 & 0.2383 & 0.1926 & 0.1560 \\
$\mathrm{Cu}$ & -0.5415 & 0.1441 & 0.7360 & 0.5049 \\
$\mathrm{Ni}$ & -0.2637 & -0.0607 & 0.4166 & 0.7747 \\
$\mathrm{~Pb}$ & -0.6063 & 0.8860 & -0.2221 & -0.0453 \\
$\mathrm{~V}$ & 0.0252 & -0.2847 & 0.2657 & 0.5923 \\
$\mathrm{Zn}$ & -0.1393 & -0.1278 & 0.3972 & 0.7028 \\
$\mathrm{Y}$ & -0.6983 & 0.3987 & 0.7572 & 0.2346 \\
$\mathrm{Li}$ & -0.4295 & 0.1526 & 0.5742 & 0.1275 \\
$\mathrm{La}$ & -0.6104 & 0.1534 & 0.9053 & 0.0869 \\
$\mathrm{Ce}$ & -0.6421 & 0.1965 & 0.8868 & 0.0748 \\
$\mathrm{Nd}$ & -0.5675 & 0.1015 & 0.9318 & -0.0154 \\
$\mathrm{~T}-\mathrm{N}$ & 0.0313 & -0.2680 & 0.2487 & 0.4104 \\
$\mathrm{OC}-\mathrm{MA}$ & 0.0711 & -0.3009 & 0.2329 & 0.3743 \\
$\mathrm{TS}$ & -0.3697 & 0.5058 & -0.1390 & 0.2206 \\
$\mathrm{Variance}$ & 41.368 & 22.218 & 22.219 & 6.479 \\
$\mathrm{Cum}$. Var. & 41.368 & 63.585 & 85.805 & 92.284 \\
\hline & & & & \\
\hline
\end{tabular}

are associated with the carbonate fraction and not the clastic or organic fractions. We interpret factor 2 as composite "carbonate" chemical end member characterized by relatively high concentrations of $\mathrm{Pb}, \mathrm{Mn}, \mathrm{P}$, and $\mathrm{S}$. Factors 1 and 2 together explain $63 \%$ of the variance in the transformed (percent of range) data. A plot of loadings for factor 1 versus those for factor 2 is shown in Figure 15. Like most other cross-plots, particularly of inorganic geochemical data, Q-mode factors 1 and 2 clearly separate the claystones from the two carbonate types, but do not produce a clear distinction among the carbonate lithologies.

Factor 3 loadings correlate most highly with the light rare-earth elements $\mathrm{Ce}, \mathrm{La}, \mathrm{Y}$, and $\mathrm{Nd}$, as well as $\mathrm{Mg}$, $\mathrm{Cu}, \mathrm{Fe}, \mathrm{P}$, and $\mathrm{Li}$ (Table 10). We first thought that the high concentrations of $\mathrm{Mg}$, the rare-earth elements (REE), and possibly $\mathrm{Cu}$ and $\mathrm{Fe}$ in the carbonate lithologies, relative to the concentrations in the black claystones (Fig. 14), might be the result of substitution for $\mathrm{Ca}$ in calcite, as discussed earlier for Mn. The REE are known to be concentrated in alkaline-earth minerals (e.g., calcite, strontianite, apatite, barite, etc.) where the trivalent REE ions occupy lattice positions of divalent ions (Goldschmidt, 1958; Goldberg et al., 1963; Guichard et al., 1979; Elderfield and Greaves, 1982).

Correlation coefficients between amount of $\mathrm{CaCO}_{3}$ and whole-rock concentrations of $\mathrm{La}, \mathrm{Ce}$, and $\mathrm{Nd}$ are $-0.54,-0.44$, and -0.23 , respectively. Thus, $\mathrm{CaCO}_{3}$ and the REE are negatively correlated, not positively correlated, as would be expected if the REE were substituting for $\mathrm{Ca}$ in calcite. Elderfield et al. (1981) found that the main mineral phase controlling the concentrations of REE in surface sediments of the equatorial Pacific was phosphatic. Consequently, the high correlation between REE and $\mathrm{P}_{2} \mathrm{O}_{5}$ in the Neocomian carbonates of Hole 603B may indicate the presence of a phosphatic mineral phase with high REE concentrations. Similarly, the negative correlation between concentrations of $\mathrm{CaCO}_{3}$ and $\mathrm{Mg}(r=-0.97)$ and the positive correlation be-

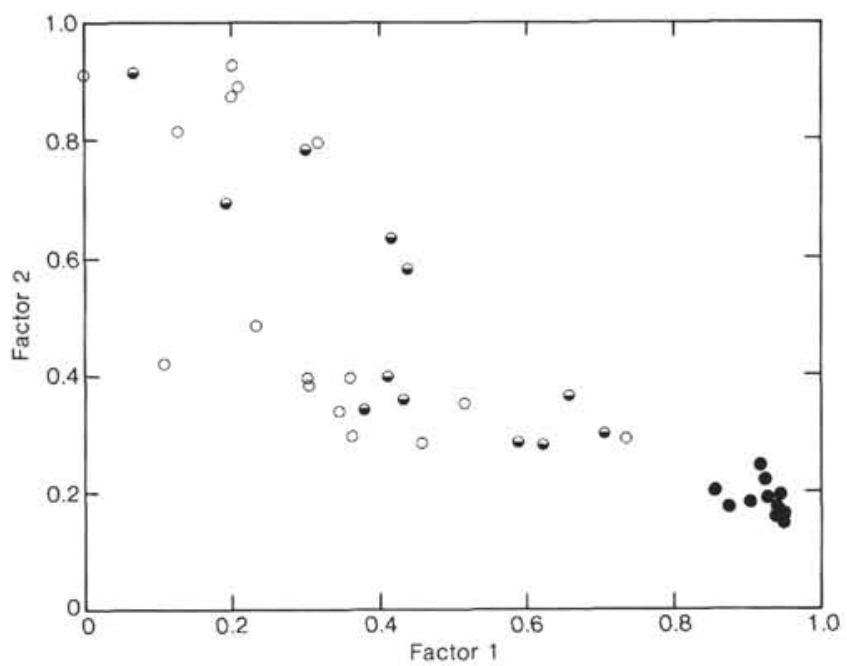

Figure 15. Plot of Q-mode factor loadings for factor 1 and factor 2 for samples of the three Neocomian lithologic types of Hole 603B. Symbol designations are the same as in Figure 4. 
tween $\mathrm{Mg}$ and all three REE (e.g., $\mathrm{Mg}$ versus $\mathrm{Ce}$, Fig. 16) suggest that the REE also may reside in a $\mathrm{Mg}$-bearing mineral phase (e.g., dolomite?).

Cerium can exist as both the trivalent Ce(III) ion and the tetravalent $\mathrm{Ce}$ (IV) ion, and is therefore sensitive to redox conditions (Goldberg et al., 1963; Piper, 1974; Elderfield and Greaves, 1982). For example, deep-sea ferromanganese nodules usually have concentrations of $\mathrm{Ce}$ higher than those of either $\mathrm{La}$ or $\mathrm{Nd}$ (positive $\mathrm{Ce}$ anomaly; Goldberg et al., 1963; Piper, 1974; Addỳ, 1979; Elderfield et al., 1981). Seawater, on the other hand, usually has a negative Ce anomaly (Goldberg et al., 1963; Elderfield and Greaves, 1982). The positive Ce anomaly in nodules and negative $\mathrm{Ce}$ anomaly in seawater has been used as evidence that the REE in nodules precipitate from seawater (Piper, 1974; Addy, 1979; Elderfield et al., 1981). In fact, Piper suggested that the negative $\mathrm{Ce}$ anomaly in seawater resulted from selective incorporation of $\mathrm{Ce}(\mathrm{IV})$ as $\mathrm{CeO}_{2}$ along with $\mathrm{MnO}_{2}$ in the nodules. Piper (1974) further suggested that variations in the $\mathrm{Ce}$ anomaly in ferromanganese nodules may result from variations in redox conditions in the sedimentary environment. Typical shale also has a positive Ce anomaly, and some investigators choose to normalize REE concentrations to average-shale REE concentrations in order to measure variations from the shale REE pattern in various sedimentary materials (Haskin and Haskin, 1966; Piper, 1974; Piper and Graef, 1974; Addy, 1979; Elderfield et al., 1981). Because of the sensitivity of Ce to changes in redox conditions, we expected that the large differences in $\mathrm{Ce}$ concentration in the Neocomian carbonates in Hole $603 \mathrm{~B}$ might be due to variations in redox conditions during early diagenesis, and that they might therefore provide a distinction between the bioturbated white limestones and laminated marlstones and limestones. The strong correlation between $\mathrm{Ce}$ and $\mathrm{Mg}$ (Fig. 16), on both a whole-rock and a carbonate-free basis, suggested that perhaps the oxidized form of $\mathrm{Ce}$ might be substituting for $\mathrm{Mg}$ in some mineral phase, because $\mathrm{Ce}$ (IV) has an ionic radius $(0.8 \AA)$ close to that of $\mathrm{Mg}(\mathrm{II})$, whereas the ionic radius of the reduced form $[\mathrm{Ce}(\mathrm{III})=1.07 \AA]$ is closer to that of $\mathrm{Ca}(\mathrm{II})$. But concentrations of the other light REE ( $\mathrm{La}$ and $\mathrm{Nd}$ ) also correlate with $\mathrm{Mg}$ concentrations, and there are no changes in the relative proportions (ratios) of the three REE that might suggest redox fractionation of Ce. Also, as can be seen from Figure 16 , no clear distinction between the carbonate lithologies can be drawn on the basis of concentrations of $\mathrm{Mg}$ and $\mathrm{Ce}$. Further, the $\mathrm{Mg}$ and REE concentrations are not functions of either $\mathrm{CaCO}_{3}$ or $\mathrm{OC}$ concentrations. All these observations indicate that there has been no redox fractionation to separate $\mathrm{Ce}$ from $\mathrm{La}$ and $\mathrm{Nd}$, and there is no obvious difference in lithology between highand low-REE carbonates.

We are still left with the question of why some of the Neocomian carbonates from Hole 603B have high REE concentrations. To determine how distinctive these REE concentrations are, and whether they occur in other carbonate sequences, we examined many of our own data sets, as yet mostly unpublished. Some results of analyses of $\mathrm{La}, \mathrm{Ce}$, and $\mathrm{Nd}$ from these data sets are summa-
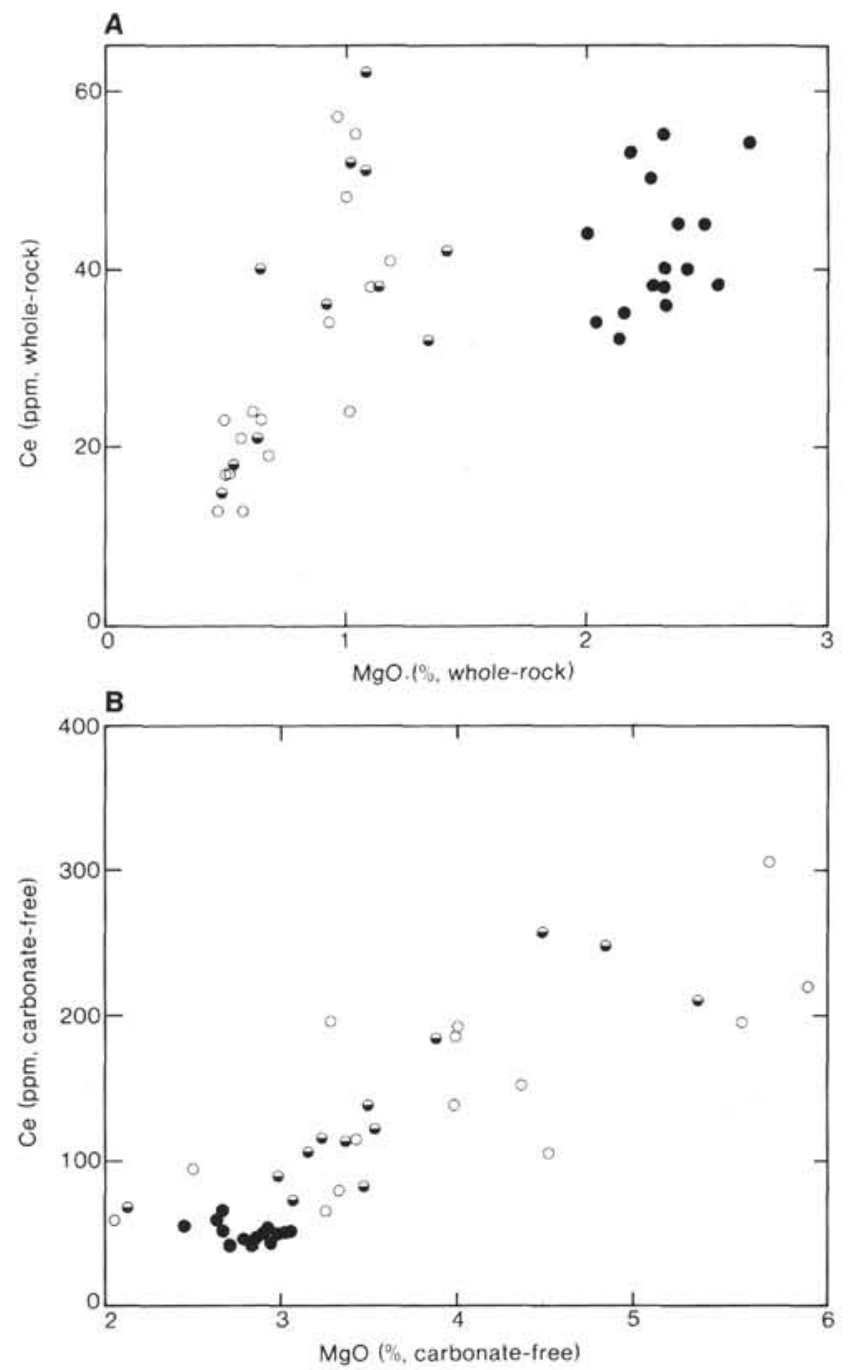

Figure 16. Plots of percent $\mathrm{MgO}$ versus ppm $\mathrm{Ce}$ on (A) a whole-rock and (B) a carbonate-free basis, for the three Neocomian lithologic types of Hole 603B. Symbol designations as in Figure 4.

rized in Table 11. As already mentioned, modern seawater generally has a negative $\mathrm{Ce}$ anomaly, so any mineral phase that precipitates from seawater, such as $\mathrm{CaCO}_{3}$, should have a Ce concentration lower than the concentrations of $\mathrm{La}$ or $\mathrm{Nd}$, and the concentrations of all REE should be low. Modern carbonate skeletal debris (e.g., foraminifers and pteropods) generally show these relationships (e.g., Turekian, et al., 1973; Piper and Graef, 1974; Elderfield et al., 1981). Pelagic chalks from DSDP Site 585 in the western Pacific (Table 11) do have fairly low REE concentrations, and the Ce concentration generally is the lowest of the three light REE. However, in carbonate sediments from high-productivity upwelling areas off Southwest Africa (DSDP Holes 530A, 530B, and 532; Dean and Parduhn, 1984), the Ce concentration generally is higher than the concentrations of $\mathrm{La}$ and Nd (Table 11). REE concentrations in samples of Neocomian carbonates from other sites in the Atlantic usually are lower than those in the samples from Site 603 , although for most samples from these other sites we have data only for $\mathrm{Ce}$ (Table 11). Light-REE concen- 
Table 11. Concentrations (ppm, whole rock) of light rare-earth elements (REE) $\mathrm{La}, \mathrm{Ce}$, and Nd in selected samples.

\begin{tabular}{|c|c|c|c|c|c|c|c|c|c|c|}
\hline \multirow[b]{2}{*}{ Material } & \multicolumn{3}{|c|}{$\mathrm{La}$} & \multicolumn{3}{|c|}{$\mathrm{Ce}$} & \multicolumn{3}{|c|}{$\mathrm{Nd}$} & \multirow[b]{2}{*}{$\mathrm{La} / \mathrm{C}$} \\
\hline & Min. & Max. & Mean & Min. & Max. & Mean & Min. & Max. & Mean & \\
\hline Average shalea & & & 39 & & & 76 & & & 37 & 0.51 \\
\hline Average shale b & & & 41 & & & 83 & & & 38 & 0.49 \\
\hline \multicolumn{11}{|l|}{ Black shales } \\
\hline DSDP Site $367^{c}$ & 12 & 49 & 29 & 12 & 72 & 42 & 11 & 42 & 24 & 0.69 \\
\hline DSDP Site $368^{\circ} \mathrm{C}$ & 16 & 100 & 44 & 27 & 120 & 75 & 8 & 92 & 37 & 0.59 \\
\hline DSDP Site $386^{c}$ & 9 & 65 & 32 & 11 & 140 & 62 & 7 & 67 & 29 & 0.52 \\
\hline \multicolumn{11}{|l|}{ Hole 603B, Unit IV } \\
\hline Black claystone & 18 & 45 & 36 & 25 & 100 & 75 & 17 & 44 & 35 & 0.48 \\
\hline Green claystone & 36 & 49 & 40 & 68 & 100 & 83 & 28 & 50 & 44 & 0.48 \\
\hline Red claystone & 35 & 49 & 41 & 75 & 110 & 92 & 28 & 45 & 40 & 0.43 \\
\hline Phillipsited & & & 167 & & & 55 & & & 169 & 3.04 \\
\hline Seawater $\left(\times 10^{7}\right)^{\mathrm{d}}$ & & & 34 & & & 12 & & & 28 & 2.83 \\
\hline \multicolumn{11}{|l|}{ Chalkse } \\
\hline $585-17-2,43 \mathrm{~cm}$ & & & 31 & & & 21 & & & 33 & 1.48 \\
\hline $585-20-3,20 \mathrm{~cm}$ & & & 33 & & & 21 & & & 23 & 1.58 \\
\hline $585 \mathrm{~A}-3-1,137 \mathrm{~cm}$ & & & 36 & & & 52 & & & 32 & 0.69 \\
\hline \multicolumn{11}{|l|}{ Nannofossil oozesf } \\
\hline $530 \mathrm{~A}-70-4,145 \mathrm{~cm}$ & & & 25 & & & 60 & & & $<50$ & 0.42 \\
\hline $530 \mathrm{~B}-6-3,34 \mathrm{~cm}$ & & & 14 & & & 80 & & & $<50$ & 0.18 \\
\hline $532-3-2,45 \mathrm{~cm}$ & & & 7 & & & $<30$ & & & $<50$ & \\
\hline \multicolumn{11}{|l|}{ Neocomian carbonates } \\
\hline DSDP Site 1058 & & & & $<10$ & 20 & 18 & & & & \\
\hline DSDP Site 3678 & & & & $<10$ & 30 & 19 & & & & \\
\hline DSDP Site 3878 & & & & $<10$ & 20 & & & & & \\
\hline DSDP Site 3918 & 4 & 18 & 9 & 4 & 34 & 17 & $<4$ & 14 & 8 & 0.53 \\
\hline \multicolumn{11}{|l|}{ Hole 603B, Unit V } \\
\hline White limestone & 5 & 26 & 16 & 13 & 57 & 39 & 7 & 41 & 21 & 0.53 \\
\hline Laminated limestone & 7 & 33 & 19 & 15 & 62 & 34 & 9 & 44 & 25 & 0.56 \\
\hline & 19 & 31 & 24 & 32 & 55 & 42 & 16 & 40 & 26 & 0.57 \\
\hline \multicolumn{11}{|l|}{ Other $\mathrm{K}$. carbonates } \\
\hline DSDP Site $364 \mathrm{~h}$ & 6 & 130 & 27 & 11 & 250 & 45 & $<6$ & 110 & 24 & 0.64 \\
\hline Niobrarah & 12 & 36 & 22 & $<10$ & 48 & 27 & $<9$ & 34 & 17 & 0.81 \\
\hline Greenhorn $^{\mathrm{h}}$ & 5 & 35 & 14 & $<8$ & 51 & 20 & & & & 0.70 \\
\hline
\end{tabular}

a Turekian, 1972.

b Piper, 1974; unweighted average of shales from Europe, North America, and Russian platform, from Haskin and Haskin (1966).

c Dean and Arthur, unpublished data; Hole 367, Cores 18-23; Hole 368, Cores 57-63; Hole 387, Cores 29-33.

d Piper, 1974.

e Dean, unpublished data; chalks from western Pacific, DSDP Site 585, Mariana Basin

f Dean and Parduhn, 1984.

8 Dean and Arthur, unpublished data; DSDP Hole 105, Cores 18-25; Hole 367, Cores 25-27, 31; Hole 387, Cores

39-40; Hole 391C, Cores 24, 28, 31, and 37.

h Dean and Arthur, unpublished data, DSDP Hole 364, Cores 39-45, Angola Basin, Southwest Africa; Niobrara and Greenhorn formations, Cretaceous Western Interior Basin, Colorado.

trations in limestone-marlstone cycles in Cretaceous carbonates from the Western Interior Basin of the U.S. (Niobrara and Greenhorn limestones) also are fairly high (Table 11). In the Western Interior carbonates, as in the Neocomian at Site 603, the REE are positively associated with $\mathrm{Mg}$ and $\mathrm{P}$. Some of the highest light-REE concentrations we found in our data sets were in cyclic interbeds of dolomitic limestone, marlstone, and black shale of Aptian/Albian age from Site 364 off Southwest Africa (Table 11). Because of the association of REE and $\mathrm{Mg}$ in the samples from Site 603 and in the Cretaceous carbonates from the Western Interior, we thought that the REE in the samples from Site 364 might be the result of incorporation in the dolomitic beds. Concentrations of REE in the 364 samples are not correlated with concentrations of either $\mathrm{Mg}$ or $\mathrm{P}$, however, but are highly correlated with concentrations of $\mathrm{Mn}$ and $\mathrm{Sr}$ - the exact opposite of the relationships in the 603 samples. From all the above considerations, we conclude that the high REE concentrations in the Neocomian carbonates of Hole $603 \mathrm{~B}$ are somewhat unusual; but we have no clear idea why some laminated and bioturbated carbonates are en- riched in REE (and $\mathrm{Mg}$ and $\mathrm{P}$ ) and others are not, unless such patterns are related to variable hydrothermal influence, as we will suggest in a moment.

Factor 4 loadings correlate most highly with the trace transition elements $\mathrm{Co}, \mathrm{Ni}, \mathrm{Zn}, \mathrm{V}$, and $\mathrm{Cu}$ (Table 9). We are not sure of the residence of these elements. Initially, we thought that the trace transition elements might be associated with the more marine organic matter in the laminated carbonates, but, as indicated in Figure 12B, there is no systematic difference in the concentrations of $\mathrm{Ni}$ and $\mathrm{Co}$ between the bioturbated and laminated carbonates. Also, there is no correlation between the concentration of organic carbon and the concentration of any of the trace transition elements, as there commonly is in marine black shales (see "Characteristics of Organic Matter" in the next section).

When we consider the element associations grouped under factors 2,3 , and 4 together, we suspect that what the factor analysis is detecting is the influence of hydrogenous and (or) hydrothermal materials. If we were dealing with Pacific pelagic clay-rich strata, these associations probably would not be so subtle, but in the At- 
lantic, the gross characteristics of hydrogenous and hydrothermal material are masked by pelagic carbonate material and turbiditic detrital clastics. Concentrations of $\mathrm{REE}, \mathrm{Fe}, \mathrm{Mn}, \mathrm{P}, \mathrm{Mg}, \mathrm{Li}, \mathrm{Zn}, \mathrm{Ni}$, and $\mathrm{Cu}$ typically are enriched in metalliferous sediments accumulating at ridge crests in the Atlantic and Pacific (e.g., Heath and Dymond, 1977; Corliss et al., 1978; Shearme et al., 1983; Dymond et al., 1984; Boyle, 1981; Owen and Rea, 1985). $\mathrm{Mn}, \mathrm{Co}, \mathrm{Ni}$, and $\mathrm{Cu}$ are strongly fractionated into hydrogenous sediments (e.g., ferromanganese nicronodules), and other trace transition elements such as $\mathrm{Zn}$ and V usually are also enriched (e.g., Krauskopf, 1956; Calvert and Price, 1977; Heath and Dymond, 1977; Glasby et al., 1978; Li, 1982; Dymond et al., 1984). Sediments in the Pacific with clear indications of hydrothermal and/ or hydrogenous chemical components accumulated slowly in oxic environments. The Neocomian sediments at Site 603 , on the other hand, accumulated rapidly, and remobilization of many elements under anoxic diagenetic conditions may have severely modified the original hydrothermal and hydrogenous chemical signals.

As shown in Table 9, factor 1 ("clastic" factor) is dominant in samples with $<30 \% \mathrm{CaCO}_{3}$. Factor 1 characteristics also are dominant in samples containing 30 to $70 \% \mathrm{CaCO}_{3}$, but additional characteristics of factors 3 and 4 (the "rare-earth" and "transition-element" factors) are also present. Samples containing 70 to $80 \%$ $\mathrm{CaCO}_{3}$ generally have highest factor loadings for factors 4 and 3 , in that order. Samples with highest loadings on factor 2 also are among the samples that have the highest $\mathrm{CaCO}_{3}$ contents $(>80 \%)$, reflecting the fact that several laminated and bioturbated limestone samples contain high concentrations of $\mathrm{Mn}$ and $\mathrm{Pb}$ (Fig. 14A) and of P and S (Fig. 11).

The results of the Q-mode factor analysis generally support the subjective subdivision of the Neocomian carbonates in Hole 603B into two end members (types 1 and 2) and an intermediate lithology (type 3). The homogenous black calcareous claystones (type 2) are clearly distinct from the carbonate lithologies on the basis of geochemical characteristics of the clastic fraction, as well as on the basis of geochemical characteristics of the organic matter. There is considerable overlap, however, in the carbonate-free inorganic geochemical characteristics of the bioturbated limestones (type 1) and the intermediate laminated marlstones and limestones (type 3). The "smearing out" of geochemical characteristics of the carbonate lithologies appears to be the result of varying degrees of mixing of weathered clastic material from eastern North America (characterized by low sodium and aluminum) and less weathered clastic material from Northwest Africa (characterized by high sodium and aluminum). The best separation of the three lithologic types is based on organic geochemical characteristics which express conditions of variable source and degree of preservation of the organic matter. The organic matter in the black claystones is low in nitrogen, hydrogen, and phosphorus, and is primarily of terrestrial origin. The carbonate lithologies contain more marine organic matter, as indicated by higher concentrations of hydrogen (higher $\mathrm{H}$-index) and lighter $\delta^{13} \mathrm{C}$ values. Geochemi- cally, the main distinction between the bioturbated and laminated carbonates (types 1 and 3 ) is the better degree of preservation of the organic matter in the laminated marlstones and limestones.

\section{Lithologic Unit IV-Carbonaceous Claystones}

The end of deposition of the Neocomian carbonates apparently was caused by a sudden rise in the CCD (Thierstein, 1979; Arthur and Dean, 1986), and the remainder of the section through the Eocene in the North Atlantic, at paleodepths below about $3000 \mathrm{~m}$, is dominated by multicolored clay-rich lithologies. At most sites in the North Atlantic, the Neocomian carbonates are overlain by the so-called mid-Cretaceous (Aptian-Albian to Turonian) black-shale facies, but at some sites the two are separated by a thin $(<10 \mathrm{~m})$ unit of Aptian to lower Albian interbedded red and green claystone (Jansa et al., 1978; Dean and Gardner, 1982; Arthur and Dean, 1986). An oxidized unit of the same age also occurs in sequences from the Tethyan region (Arthur and Primoli Silva, 1982). This red and green unit correspond to lithologic Unit IVD in Hole 603B (1204.8-1214.72 m; Fig. 2; Site 603 chapter, this volume).

\section{Characteristics of Organic Matter}

The mid-Cretaceous black-shale facies contains the highest concentrations of OC measured in North Atlantic sedimentary sequences, and at most DSDP sites it consists of interbedded green and black clay-rich lithologies (see reviews by Arthur, 1979a; Tucholke and Vogt, 1979; Thierstein, 1979; Tissot et al., 1979, 1980; Weissert, 1982; Dean and Gardner, 1982; Arthur, Dean, and Stow, 1984; Arthur and Dean, 1986). True black shale or claystone amounts to less than half of the black-shale facies. This unit has been named the Hatteras Formation by Jansa et al. (1979), and was recovered at DSDP Sites 138, 144, 367, 368, 370, 386, 387, 391, 398, 400, $402,415,417,418,534$, and 603 in the North Atlantic. Concentrations of $\mathrm{OC}$ in the black shales range from less than $1.0 \%$ to $37 \%$; concentrations of OC generally are higher in black shales and claystones from the eastern North Atlantic than in those from the western North Atlantic (see reviews by Tissot et al., 1979, 1980; Summerhayes, 1981, 1986; de Graciansky et al., 1982; Herbin and Deroo, 1982; Arthur and Dean, 1986). Highest concentrations of OC (usually $>34 \%$ ) occur in the Turonian section at Site 367 in the Cape Verde Basin off Northwest Africa (Herbin and Deroo, 1982). We recently measured OC concentrations of up to $52 \%$ in samples from this same section at Site 367 .

Table 8 shows that the OC concentrations in black claystones from Hole $603 \mathrm{~B}$ are at least 10 times those in interbedded green and red claystones. The average concentration of $\mathrm{OC}$ in the black claystones $(\sim 3 \%)$, however, is low relative to most mid-Cretaceous black shales in the Atlantic, particularly those in the southeastern North Atlantic (Arthur and Dean, 1986).

The differences between type of organic matter in the black and green claystones are emphasized in a "Van Krevelen-type" plot of HI versus OI (Fig. 17). The black claystones have a very narrow range of OI values but a 

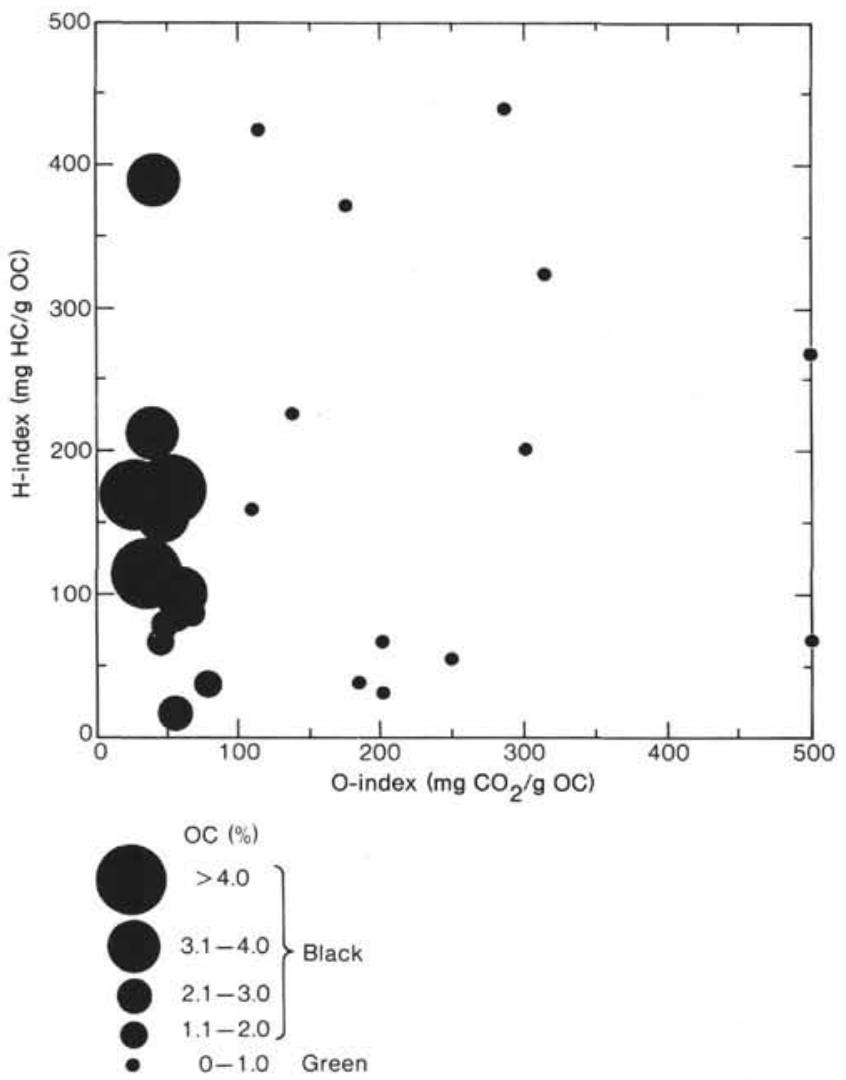

Figure 17. Plot of Rock-Eval hydrogen index versus oxygen index for samples of Aptian to Santonian green and black claystones from lithologic Unit IV, Hole 603B.

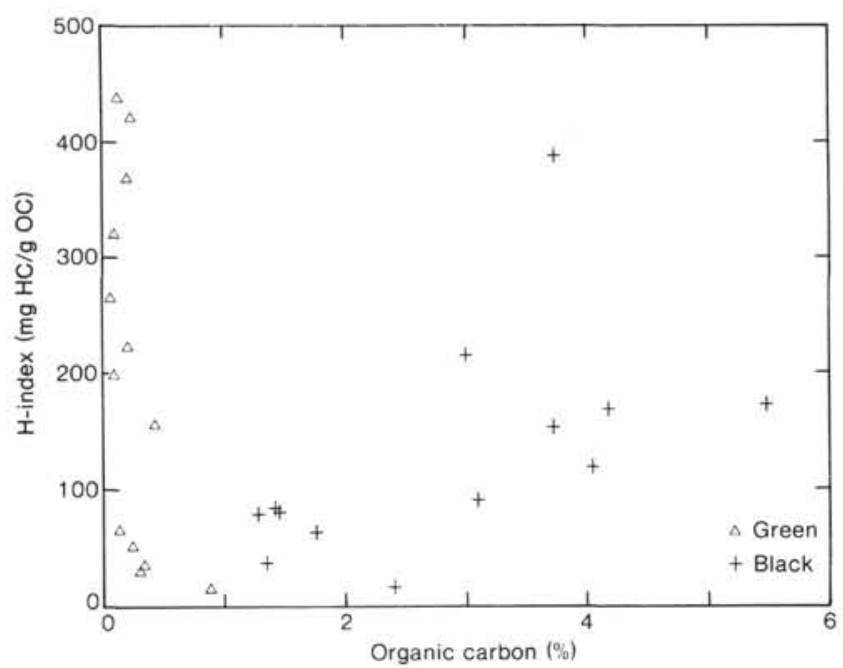

Figure 18. Plot of Rock-Eval hydrogen index versus percent organic carbon in samples of green and black claystones from lithologic Unit IV, Hole 603B.

large range of $\mathrm{HI}$ values roughly proportional to the $\mathrm{OC}$ content. The positive correlation between percent OC and Rock-Eval HI for the black claystones (Fig. 18) implies that organic matter added to a background of 1 to $2 \%$ OC was more hydrogen-rich and/or better preserved, a relationship similar to that observed between $\mathrm{OC}$ and
$\mathrm{HI}$ in all samples of Neocomian carbonates (Fig. 6). The green claystones are unusual, however, because all samples contain less than $1.0 \%$ OC (and most are $<0.3 \%$ ); but the range of values of $\mathrm{HI}$ is as great as that for black claystones (Fig. 17). The green claystones also have a large range of OI values. The large range of OI values and low concentrations of $\mathrm{OC}$ in the green claystones suggest considerable variation in degree of oxidation of organic matter in the green claystones, but the relatively high values of $\mathrm{HI}$ in many samples show that the hydrogen richness of the organic matter is preserved. The black claystones show the more normal relationship, in which the more OC-rich beds contain better-preserved organic matter and hence low OI values and high $\mathrm{HI}$ values.

As discussed earlier for the Neocomian carbonates, several other indices of source and degree of preservation of organic matter are suggested by positive correlations between weight percent $\mathrm{OC}$ and weight percentages of $\mathrm{P}_{2} \mathrm{O}_{5}$, total nitrogen, and total sulfur. These relationships are shown for the black claystones of lithologic Unit IV in Figure 19. Concentrations of $\mathrm{P}_{2} \mathrm{O}_{5}$ in both green and black claystones (Fig. 19A) are about the same as those in the Neocomian calcareous black claystones (Fig. 11). From Figures 11 and 19A, we suggest that a $\mathrm{P}_{2} \mathrm{O}_{5}$ concentration of about $0.1 \%$ is a representative average value for inorganic clastic material deposited at Site 603. Carbonate-free concentrations of $\mathrm{P}_{2} \mathrm{O}_{5}$ in Neocomian limestones and marlstones are all $>0.2 \%$ (Fig. 11 ), and probably represent phosphorus transported to the bottom with calcareous biogenic debris. Average OC/ $\mathrm{P}_{2} \mathrm{O}_{5}$ ratios for black and green claystones are 21 and 3, respectively. The greater abundance of $\mathrm{P}_{2} \mathrm{O}_{5}$, relative to $\mathrm{OC}$, in the green claystones (lower $\mathrm{OC} / \mathrm{P}_{2} \mathrm{O}_{5}$ ratio) might indicate better initial preservation of some of the organic matter in these samples, although samples with the biggest $\mathrm{HI}$ values do not have the highest $\mathrm{P}_{2} \mathrm{O}_{5}$ values (Tables 3 and 4). Alternatively, the higher $\mathrm{P}_{2} \mathrm{O}_{5}$ concentrations and $\mathrm{OC} / \mathrm{P}_{2} \mathrm{O}_{5}$ ratios in the green claystones could be due to a greater hydrothermal chemical input to the pelagic green clay, as previously reasoned for the Neocomian pelagic carbonates.

Figure 19B shows that concentrations of $\mathrm{OC}$ and total nitrogen (T-N) are highly correlated. The average $\mathrm{C} / \mathrm{N}$ ratio in the black claystones is 25 , with little variation, and is about the same as the $\mathrm{C} / \mathrm{N}$ ratio of organic matter in all Neocomian lithologies (Fig. 10). The high $\mathrm{C} / \mathrm{N}$ ratio suggests that the organic matter in the black claystones from Unit IV, like that in the black claystones from Unit V, is mainly of terrestrial origin, and probably was also redeposited by turbidity currents from shallower sites of accumulation. The average $\mathrm{C} / \mathrm{N}$ ratio in the green claystones is 12 . This lower $\mathrm{C} / \mathrm{N}$ ratio, together with low $\mathrm{C} / \mathrm{P}$ ratios and relatively high $\mathrm{HI}$ values, suggests that the organic matter in the green claystones is more marine and/or better preserved.

The concentration of $\mathrm{OC}$ also is correlated with the concentration of total sulfur (T-S) (Fig. 19C). The OC/ T-S weight ratio in modern sediments with anoxic pore waters (but not deposited in an anoxic water column) is about 2.5 (dashed line in Fig. 19C) (Goldhaber and Kaplan, 1974; Berner, 1984; Berner and Raiswell, 1984). Ar- 

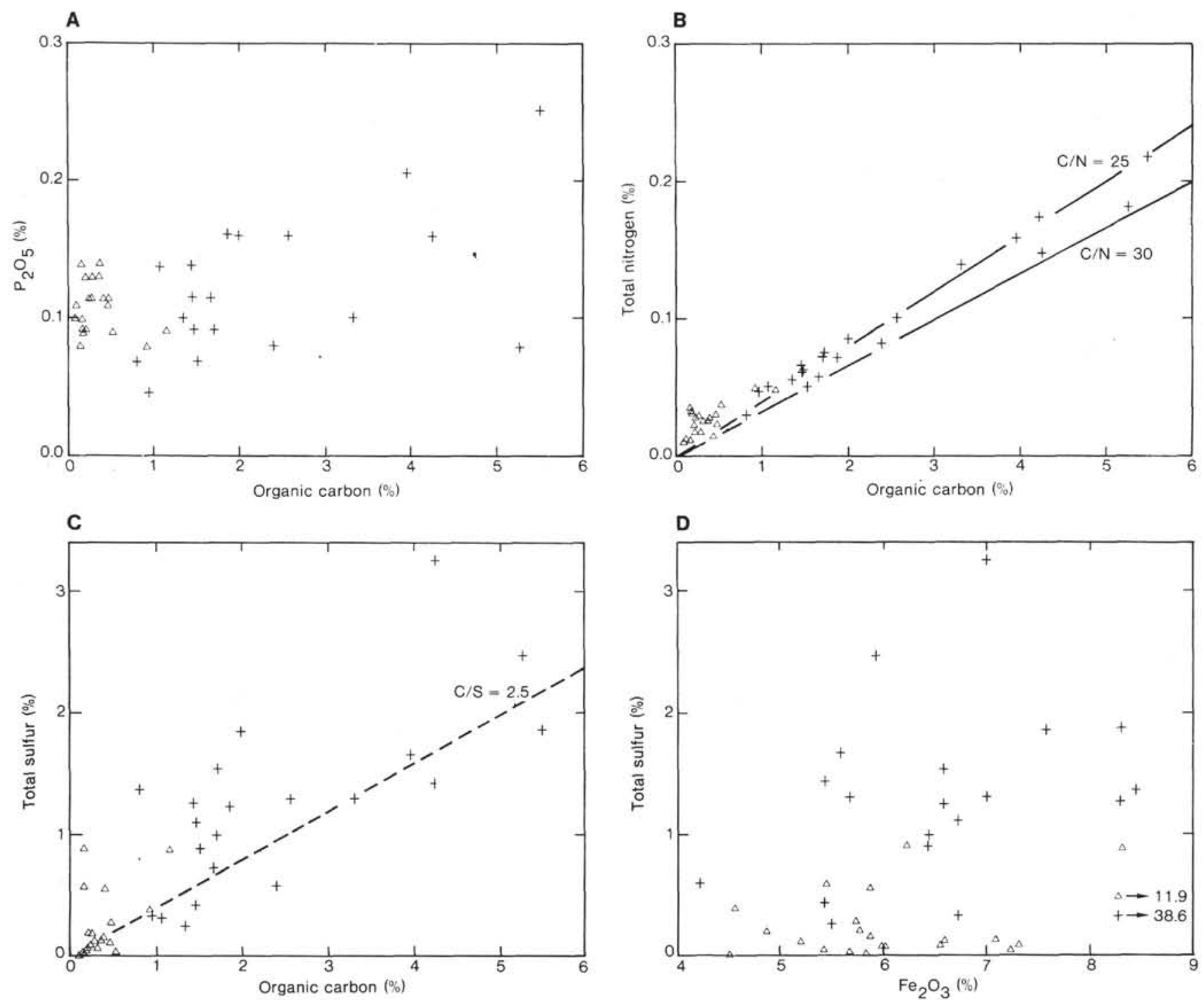

Figure 19. Plot of percent organic carbon versus (A) percent $\mathrm{P}_{2} \mathrm{O}_{5}$, (B) percent total nitrogen, and (C) percent total sulfur, and (D) percent $\mathrm{Fe}_{2} \mathrm{O}_{3}$ versus percent total sulfur in samples of green and black claystones from lithologic Unit IV, Hole 603B. Symbol designations are the same as in Figure 18.

thur, Dean, and Stow (1984) and Dean, Arthur, and Stow (1984) concluded that an OC/T-S ratio of about 2.5 also was an approximate average value for Cretaceous OCrich strata from Atlantic DSDP sites. Leventhal (1983) concluded, on the basis of OC/T-S ratios in Black Sea sediments, that sediments with OC/T-S ratios less than about 2.5 , and with a positive intercept on the S-axis of a C-S plot, were deposited in an anoxic water column. Dean, Claypool, and Thiede (1984) found that OC/T-S ratios in OC-rich middle Cretaceous strata from several sites in the western Pacific were variable from site to site, although samples from each site all showed good linear correlations between OC and T-S. They attributed this variability in OC/T-S ratio to differences in the amount of available iron and rates of diffusion of sulfur in the sediments. Kendrick (1979) measured concentrations of T-S of up to $4.3 \%$ in OC-rich strata from Sites 386 and 387 in the North Atlantic. He interpreted such high T-S concentrations as evidence of deposition and preservation of organic matter under anoxic conditions at or slightly above the seafloor. The relatively low concentrations of T-S in the black claystones of lithologic Unit IV in Hole 603B, the OC/T-S ratio close to 2.5, and the zero intercept on a C-S plot (Fig. 19C) all suggest deposition in an oxygenated water column.

Figure 19D shows that there is no correlation between the concentrations of $\mathrm{Fe}_{2} \mathrm{O}_{3}$ and total $\mathrm{S}$ (correlation coefficients $=-0.26$ and +0.24 for black and green claystones, respectively). Both green and black claystones, however, are considerably enriched in $\mathrm{Fe}_{2} \mathrm{O}_{3}$ relative to what would be expected if most of the sulfur was in pyrite $(\mathrm{S}=1.15 \mathrm{Fe})$, indicating that pyrite formation in these claystones was not iron-limited. Instead, pyrite formation in these strata during early diagenesis probably was limited by the lack of lipid-rich, reactive, marine organic matter. The weak positive correlation between T-S and $\mathrm{Fe}_{2} \mathrm{O}_{3}$ in the green claystones, but not in the black claystones, may reflect the greater proportion of marine 
and/or better-preserved organic matter in the green claystones.

Additional information on the sources of organic matter in the green and black claystones of lithologic Unit IV can be obtained from the carbon isotopic composition. The values of $\delta^{13} \mathrm{C}$ in the Neocomian strata at Site 603 , particularly compared with those in the Neocomian carbonates at Site 367, suggest that terrestrial organic matter derived from coastal environments of North America had $\delta^{13} \mathrm{C}$ values in the range of -24 to $-25 \%$, in contrast to values of -27 to $-29 \%$ in marine organic matter derived from high-productivity upwelling areas off Northwest Africa (Fig. 7). Values of $\delta^{13} \mathrm{C}$ in the black and green claystones of lithologic Unit IV have about the same range (Figs. 9 and 20) as those in the Neocomian strata, and in general the black lithologies are more depleted in ${ }^{13} \mathrm{C}$ (more negative values of $\delta^{13} \mathrm{C}$ ) than the green lithologies. Figure 20 shows considerable scatter in the data, but two possible trends are suggested. One is indicated by most of the green claystones, which have little variation in $\delta^{13} \mathrm{C}$ (between -25 and $-26 \%$ ) but considerable variation in HI. We interpret this trend as an oxidation-degradation trend, in which a mixture of terrestrial and marine organic matter in fairly constant proportions (as suggested by the small variation in $\delta^{13} \mathrm{C}$ ) has undergone variable degrees of oxidation (as suggested by the considerable variation in $\mathrm{HI}$ ). However, the heavier $\delta^{13} \mathrm{C}$ values $(-24$ to $-25 \%$ ) probably represent primarily refractory terrestrial organic matter. The second trend is indicated by most of the black claystones and those green claystones with $\mathrm{HI}$ values $<100$. We interpret this trend to be a source trend, in which all the organic matter is oxidized (low HI values) but the source signal is still preserved in the values of $\delta^{13} \mathrm{C}$ and, to a lesser degree, in the values of HI. The samples in the second (source) trend that contain more marine organic matter have higher values of $\mathrm{HI}$ and more negative values of $\delta^{13} \mathrm{C}$ (about $-27 \%$ ). One major outlier $(\mathrm{HI}=$ $390, \delta^{13} \mathrm{C}=-24.3$ in Fig. 20) has a high $\mathrm{HI}$ but heavier

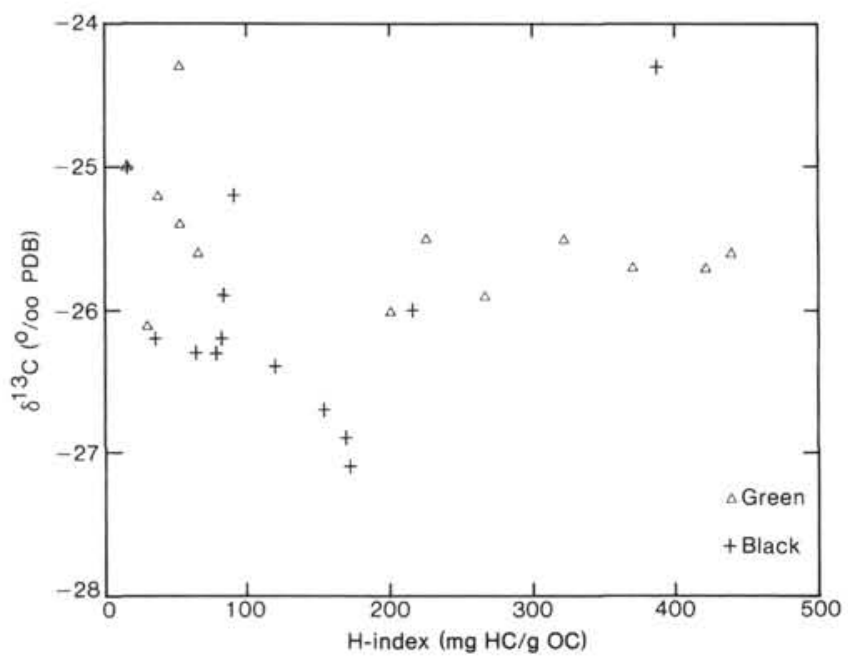

Figure 20. Plot of Rock-Eval hydrogen index versus $\delta^{13} \mathrm{C}$ in organic matter from samples of green and black claystone from lithologic Unit IV, Hole 603B. Symbol designations as in Figure 18. $\delta^{13} \mathrm{C}$ than almost any value in the data set. This sample occurs near the Cenomanian/Turonian boundary and probably reflects a worldwide positive excursion in $\delta^{13} \mathrm{C}$ of marine organic matter (Pratt and Threlkeld, 1984; Pratt, 1985; see discussion later in this section).

The data displayed in Figures 17 to 20 all seem to suggest that the organic matter in the black claystones is more abundant (higher OC concentrations) but generally more degraded (lower HI values) than organic matter in the green claystones, and that it was mainly terrestrial, mixed with some marine organic matter and deposited in well-oxygenated bottom waters. In most $\mathrm{OC}$-rich sequences there is a positive correlation between OC concentration and HI (e.g., Dean et al., 1986), and in sequences with interbedded green and black claystones the green beds generally have lower $\mathrm{HI}$ and $\mathrm{OC}$ values. For example, in a detailed study of interbedded green and black claystones at Site 530 in the Angola Basin, Deroo et al. (1984) found that the black claystones had higher values of $\mathrm{OC}$ and $\mathrm{HI}$, and in fact the highest values of both OC and HI occurred in the centers of black claystone beds. The generally higher $\mathrm{HI}$ values in the green claystones of Hole $603 \mathrm{~B}$ are therefore somewhat puzzling. An examination of stratigraphic variations in interbedding of red, green, and black claystones of lithologic Unit IV, and in several organic geochemical parameters, may shed some light on this problem.

The highest values of $\mathrm{HI}(>350)$ in either black or green claystones occur in those samples from the Cenomanian part of the section (Fig. 9). Black claystone beds also are most abundant in the Cenomanian part of the section (Fig. 2; Site 603 chapter, this volume), reaching a maximum at the Cenomanian/Turonian $(\mathrm{C} / \mathrm{T})$ boundary (Core 603B-34); the rest of lithologic Unit IV consists mainly of interbedded red and green claystones. The so-called oceanic anoxic event (OAE; Schlanger and Jenkyns, 1976) at the C/T boundary is widely recognized as a period of rapid accumulation and burial of OC-rich strata worldwide, in response to increased marine productivity (Arthur et al., 1986; Schlanger et al., 1986). This brief but widespread period of OC-enrichment may have been due to a sudden burst of productivity, resulting from more rapid deep-water turnover rates as the deep-water connection opened between the North and South Atlantic oceans (Tucholke and Vogt, 1979; Summerhayes, 1981). Or it may have been due to greater production of warm, saline deep water as the result of the late Cenomanian to early Turonian global transgression (Arthur et al., 1986). We would expect, therefore, that the proportion of marine organic matter at Site 603 (or at any other location worldwide) should increase somewhere within the Cenomanian part of the section, and that the maximum proportion of marine organic matter should occur near the $\mathrm{C} / \mathrm{T}$ boundary. For example, off Northwest Africa, highest values of OC and HI occur in the lower Turonian section at Site 367 and near the C/T boundary at Site 368 (Herbin and Deroo, 1982). At Site 530 off Southwest Africa the mid-Cretaceous stratigraphic sequence is similar to that at Site 603 , in that the dominant lithologies are red and green claystones with minor black claystone, except near the C/T boundary (Dean, 
Arthur, and Stow, 1984), where black beds make up about $50 \%$ of the section. The black beds near the $\mathrm{C} / \mathrm{T}$ boundary at Site 530 generally contain the highest values of OC and HI (Deroo et al., 1984).

The increase in numbers of black claystone beds through the Cenomanian at Site 603 (Fig. 2) may be the result of increasing accumulation of marine organic matter in an expanded and intensified oxygen-minimum zone along the continental margin of North America. If this is true, then the abundance of black beds can, as a first approximation, be taken as a measure of the relative proportion of marine organic matter in the redeposited black claystone beds. According to this model, the HI of organic matter in the black claystone beds should reach a maximum near the $\mathrm{C} / \mathrm{T}$ boundary. Results of detailed Rock-Eval pyrolysis analyses of samples of black shale beds at the C/T boundary at Sites 105 and 603 show that values of both $\mathrm{OC}$ and $\mathrm{HI}$ increase markedly just below the $\mathrm{C} / \mathrm{T}$ boundary (Herbin et al., this volume). Similarly, values of $\delta^{13} \mathrm{C}$ should be lightest (most negative) near the C/T boundary. Figure 9 shows that samples with high values of $\mathrm{HI}$ and more negative values of $\delta^{13} \mathrm{C}$ occur in the Cenomanian section. The one exception to this is our only sample from Core 603B-34, closest to the $\mathrm{C} / \mathrm{T}$ boundary, which has the highest $\mathrm{HI}$ value (390) of any of our black claystone samples but the heaviest value of $\delta^{13} \mathrm{C}(-24.3$; Figs. 9 and 20). This heavy $\delta^{13} \mathrm{C}$ value can be explained, as stated earlier, by secular variations in the isotopic composition of the global oceanic carbon pool across the $\mathrm{C} / \mathrm{T}$ boundary. Rapid burial of marine organic matter in response to the $\mathrm{C} / \mathrm{T}$ marine productivity event removed isotopically light organic carbon at a rate sufficiently high to produce a major increase in $\delta^{13} \mathrm{C}$ of the marine carbonate-carbon reservoir (Scholle and Arthur, 1980; Arthur, Dean, and Schlanger, 1985; Schlanger et al., 1986), and there is evidence that this secular trend also caused an increase in the $\delta^{13} \mathrm{C}$ of marine OC by as much as 3.5 to $4.0 \%$ (Pratt and Threlkeld, 1984; Pratt, 1985). If we subtract $3.5 \%$ from the $\delta^{13} \mathrm{C}$ value of our Core 603B-34 sample, this new value $(-27.8)$ becomes our lightest and therefore most marine.

\section{Inorganic Geochemistry}

Enrichment of certain trace elements-especially the trace transition elements $\mathrm{Cu}, \mathrm{Zn}, \mathrm{Mo}, \mathrm{V}, \mathrm{Ni}$, and $\mathrm{Cr}-$ in $\mathrm{OC}$-rich sediments and rocks is well known (e.g., Tourtelot, 1964; Wedpohl, 1964; Brongersma-Sanders, 1965; Calvert and Price, 1970; Volkov and Fomina, 1974; Chester et al., 1978; Brongersma-Sanders et al., 1980; Brumsack, 1980; Dean and Gardner, 1982; Dean and Parduhn, 1984). The association of high trace-element concentrations with organic matter may be the result of concentration of these elements by organisms, by chemical sorption and precipitation with organic detritus, clays, etc. falling through the water column, or by formation of sulfides under anoxic conditions created by a flux of excess organic matter. Marine plankton are known to concentrate trace elements, especially $\mathrm{Ba}, \mathrm{Pb}, \mathrm{Ni}, \mathrm{Cu}, \mathrm{Zn}$, $\mathrm{Mn}$, and $\mathrm{Fe}$ (e.g., Vinogradov, 1953; Goldberg, 1957; Boyle and Lynch, 1968; Knauer and Martin, 1973; Mar- tin and Knauer, 1973; Boström et al., 1974; Chester et al., 1978; Moore and Boström, 1978; Leinen and Stakes, 1979; Collier and Edmond, 1984), and this suggests that concentration by organisms is a potentially important mechanism for incorporation of certain trace elements in OC-rich marine sediments. Studies on the factors controlling the enrichment of $\mathrm{V}$ and $\mathrm{Ni}$ in $\mathrm{OC}$-rich strata (Lewan and Maynard, 1982) showed that high concentrations (>100 ppm in bitumen) of these two elements are observed only in bitumens associated with H-rich kerogen (type II and type I kerogens of Tissot and Welte, 1978) and under conditions of rapid burial of the organic matter.

The great effectiveness of adsorption of trace elements by clays and, most important, by organic matter, and coprecipitation of trace metals, particularly as sulfide minerals, suggest that these processes also may play an important role in the removal of trace elements from seawater (e.g., Tourtelot, 1964; Brewer and Spencer, 1974; Volkov and Fomina, 1974; Holland, 1979; Balistrieri et al., 1981; Balistrieri and Murray, 1984; Jacobs et al., 1985). For example, Jacobs et al. (1985) clearly demonstrated the removal of a number of transitional metals, especially $\mathrm{Zn}, \mathrm{Cd}, \mathrm{Cu}, \mathrm{Co}, \mathrm{Mo}$, and $\mathrm{Pb}$, from the water of an anoxic fjord in Norway by metal sulfide precipitation just below the $\mathrm{O}_{2} / \mathrm{H}_{2} \mathrm{~S}$ interface. As a result, the sediment in this fjord is enriched in these metals. Bralower and Thierstein (1986) found that mid-Cretaceous OCrich strata have higher transition-metal accumulation rates than do Holocene sediments, where accumulation rates are dominated by the supply of detrital and organic materials. They concluded that the high accumulation rates of transition metals in Cretaceous strata have no clear modern analogues, but precipitation of transition-metal sulfides in euxinic basins may have been important. Holland (1984), on the other hand, suggested that scavenging from seawater alone can account for most enrichments of metals in Precambrian and Phanerozoic carbonaceous shales.

Summary statistics for concentrations of major, minor, and trace elements in black, green, and red claystones from lithologic Unit IV of Hole 603B are given in Table 7, and the ranges and geometric mean concentration are plotted in Figure 21. We used geometric means in Table 7 and Figure 21 because the concentrations of most trace and minor elements tend to approximate a log-normal distribution more closely than a normal distribution, and we therefore believe that a geometric mean is a better measure of central tendency for most elements than an arithmetic mean. In addition, the combination of the geometric mean (GM) and geometric deviation (GD) provides an easy method of determining the expected ranges of elemental composition. For example, concentrations of a particular element in about two-thirds of randomly selected samples are expected to fall within the range defined as GM/GD to GM $\times \mathrm{GD}$, and concentrations in about $95 \%$ of the samples are expected to fall within the range defined as $\mathrm{GM} /(\mathrm{GD})^{2}$ to $\mathrm{GM} \times$ $(\mathrm{GD})^{2}$. In Figure 21A we have also plotted the ranges and arithmetic mean concentrations of $\mathrm{OC}, \mathrm{T}-\mathrm{S}$, and T-N from Table 8. 
A

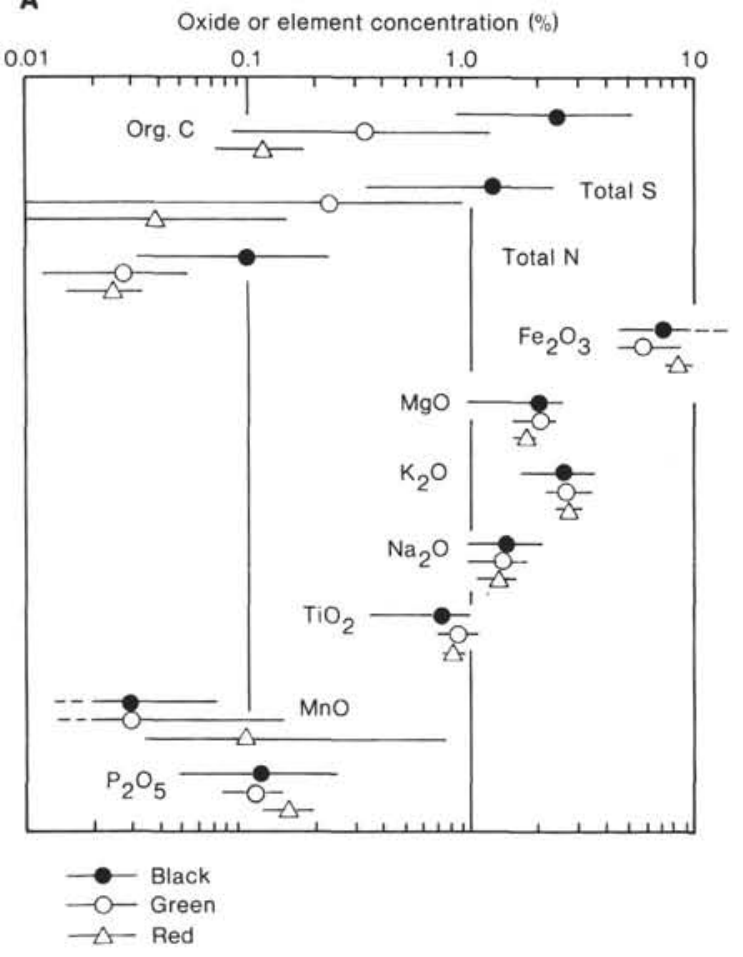

B

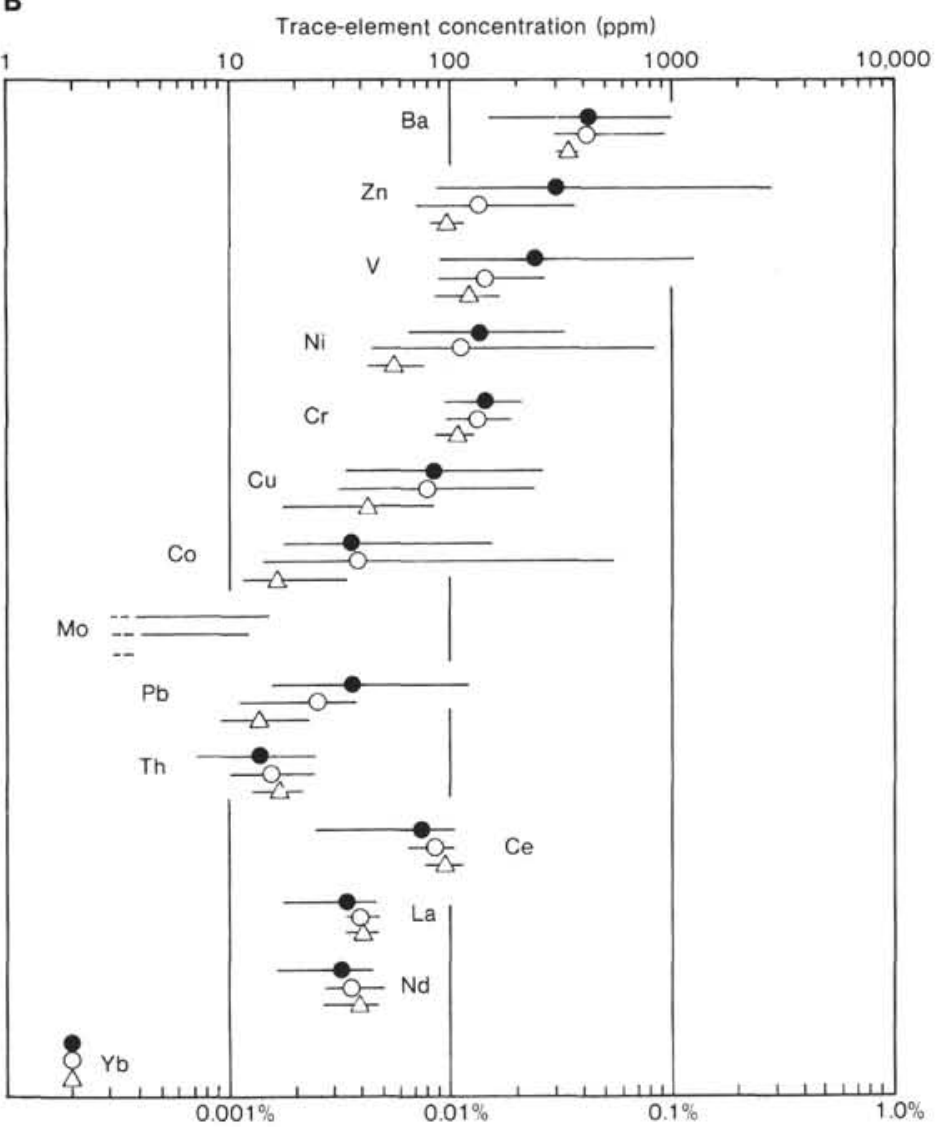

Figure 21. Comparison of concentrations of (A) major elements and oxides and (B) trace elements in samples of red, green, and black claystones from lithologic Unit IV, Hole 603B. Bars indicate the total observed ranges of element or oxide concentration; symbols are plotted on the geometric or arithmetic mean concentration for each element or oxide (Tables 7 and 8 ).

To compare element concentrations in the claystone samples from Site 603 with those in other clay-rich marine sequences, we compiled average compositions of clays and claystones from many different sources (Table 12). Because most of the average values in this compilation were arithmetic means, the averages for the Site $603 \mathrm{sam}$ ples shown in Table 12 are arithmetic means, and therefore are somewhat higher than the geometric means given in Table 7. To facilitate comparison of concentrations of some of the transition trace elements commonly reported as being high in OC-rich sediments and rocks, we plotted in Figure 22 the mean concentration of $\mathrm{Cu}, \mathrm{Co}$, $\mathrm{Ni}, \mathrm{Cr}, \mathrm{V}$, and $\mathrm{Zn}$ in selected sample sets of clays and claystones as histograms. For purposes of comparison, the most important averages in Table 12 and Figure 22 are those for average black shales and "metal-rich" black shale. Two average black shales are shown. First is the average black shale of Vine and Tourtelot $(1969,1970)$, in which concentrations are given as the median of medians of concentrations in 20 sets of black shale samples. The second is average upper Devonian black shale, in which concentrations are given as the arithmetic means of concentrations in up to 400 samples, as reported by Leventhal and colleagues (Leventhal, 1980; Leventhal et al., 1981, 1984; Leventhal and Hosterman, 1982). The concentration of each element considered by Vine and Tourtelot (1970) as the lower limit of metal-rich black shales also is shown in Figure 22. This value is the 90th percentile of concentrations in black-shale samples from their 20 data sets.

Black shales from Site 603 are enriched in many elements with respect to average continental crust, average nonblack shale, and average deep-sea clays, but are not particularly enriched in any element relative to other black shales (Table 12, Fig. 22). On the basis of our own analyses, published and unpublished, of over 500 samples of OC-rich mid-Cretaceous rocks from the North and South Atlantic, and other analyses available in the literature, the most metal-rich OC-rich rocks are black shales from Site 530 in the Angola Basin (Dean and Parduhn, 1984) and Sites 367 and 368 off Northwest Africa (Dean and Arthur, unpublished data). The organic matter in the black shales from Sites 367 and 368 off Northwest Africa is, in general, the most hydrogen-rich organic matter of any in black shales in the North Atlantic. Table 12 and Figure 22 show that even for these three sites the black shales are enriched in only a few elements, if we use the 90th-percentile limits of the Vine and Tourtelot (1970) data sets to define metal enrichment.

Because the black shales from Sites 367 and 368 are among the most metal-enriched, and are also the richest in amount of organic matter and the hydrogen content of that organic matter; because Lewan and Maynard (1982) found that metals, especially V and $\mathrm{Ni}$, are en- 
Table 12. Average concentrations of major-element oxides and trace elements (see note for identification of sample groups).

\begin{tabular}{|c|c|c|c|c|c|c|c|c|c|c|c|}
\hline Sample & $\begin{array}{c}1 \\
\text { Avg. crust }\end{array}$ & $\stackrel{2}{2}$ Avg. shale & $\begin{array}{l}{ }^{3} \\
\text { Pac. pelag. } \\
\text { clay }\end{array}$ & $\begin{array}{l}4 \\
\text { Avg. deep-sea } \\
\text { clay }\end{array}$ & $\begin{array}{c}5 \\
\text { Dev. shale }\end{array}$ & $\begin{array}{l}\quad 6 \\
\text { blk. shale }\end{array}$ & $\begin{array}{l}{ }^{7} \\
\text { V26-157 } \\
\text { red clay }\end{array}$ & Site $\stackrel{8}{105} \mathrm{MCC}$ & Site 603 MCC & $\begin{array}{c}10 \\
\text { Site } 603 \\
\text { Unit II }\end{array}$ & $\begin{array}{c}11 \\
\text { Site } 603 \\
\text { blk. claystone }\end{array}$ \\
\hline \multicolumn{12}{|l|}{ Oxide $(\%)$} \\
\hline $\mathrm{SiO}_{2}$ & 65.30 & 58.40 & 54.90 & 60.40 & 56.80 & - & 53.50 & 63.60 & 54.10 & 67.00 & - \\
\hline $\mathrm{Al}_{2} \mathrm{O}_{3}$ & 14.80 & 15.10 & 16.60 & 19.10 & 15.50 & 13.00 & 18.90 & 18.90 & 20.20 & 11.50 & 17.60 \\
\hline $\mathrm{Fe}_{2} \mathrm{O}_{3}$ & 5.06 & 6.75 & 7.70 & 8.93 & 6.10 & 3.00 & 8.15 & 9.48 & 6.40 & 3.87 & 8.29 \\
\hline $\mathrm{MgO}$ & 2.30 & 2.49 & 3.40 & 3.73 & 3.20 & 1.20 & 2.88 & 3.01 & 1.70 & 1.88 & 2.04 \\
\hline $\mathrm{CaO}$ & 4.02 & 3.09 & 0.70 & 1.01 & 1.30 & 2.10 & 0.81 & 0.57 & 0.37 & 0.61 & 0.63 \\
\hline $\mathrm{Na}_{2} \mathrm{O}$ & 3.29 & 1.29 & 1.30 & 1.67 & 0.49 & 0.90 & 2.02 & - & 1.13 & 1.37 & 1.48 \\
\hline $\mathrm{K}_{2} \mathrm{O}$ & 3.38 & 3.19 & 2.70 & 3.56 & 3.70 & 2.40 & 3.96 & 3.09 & 2.70 & 1.66 & 2.79 \\
\hline $\mathrm{TiO}_{2}$ & 0.71 & 0.69 & 0.78 & 0.92 & 0.75 & 0.33 & 0.84 & 0.89 & 0.90 & 0.39 & 0.27 \\
\hline $\mathrm{P}_{2} \mathrm{O}_{5}$ & 0.19 & 0.16 & 0.25 & 0.16 & - & - & 0.16 & - & 0.12 & 0.20 & 0.12 \\
\hline $\mathrm{MnO}$ & 0.09 & 0.11 & 0.56 & 0.52 & 0.04 & 0.02 & 0.14 & - & 0.33 & 0.75 & 0.03 \\
\hline \multicolumn{12}{|c|}{ Element (ppm) } \\
\hline As & 1.70 & 13.00 & - & 13.00 & 28.00 & - & - & - & - & - & - \\
\hline B & 9.00 & 100.00 & 100.00 & 230.00 & 114.00 & 50.00 & - & - & - & - & - \\
\hline $\mathrm{Ba}$ & 590.00 & 1600.00 & 3900.00 & 2300.00 & 386.00 & $<300.00$ & 503.00 & 291.00 & 340.00 & 210.00 & 440.00 \\
\hline $\mathrm{Cd}$ & 0.10 & 0.30 & 0.30 & 0.21 & - & - & - & - & - & - & - \\
\hline Co & 12.00 & 19.00 & 113.00 & 74.00 & 23.00 & 10.00 & 26.00 & 26.00 & 170.00 & 63.00 & 42.00 \\
\hline $\mathrm{Cr}$ & 70.00 & 90.00 & 64.00 & 90.00 & 68.00 & 100.00 & 89.00 & 145.00 & 130.00 & 15.00 & 139.00 \\
\hline $\mathrm{Cu}$ & 30.00 & 45.00 & 230.00 & 250.00 & 76.00 & 70.00 & 42.00 & 152.00 & 88.00 & 37.00 & 99.00 \\
\hline $\mathrm{Ga}$ & 17.00 & 19.00 & - & 20.00 & 21.00 & 20.00 & 31.00 & - & 27.00 & 2.90 & 24.00 \\
\hline $\mathrm{Li}$ & 30.00 & 66.00 & - & 57.00 & - & - & 94.00 & - & 87.00 & 18.00 & 70.00 \\
\hline $\mathrm{Ni}$ & 44.00 & 68.00 & 210.00 & 225.00 & 95.00 & 50.00 & 58.00 & 177.00 & 200.00 & 76.00 & 153.00 \\
\hline $\mathrm{Pb}$ & 15.00 & 12.00 & 34.00 & 80.00 & 27.00 & 20.00 & 20.00 & 42.00 & 28.00 & 15.00 & 42.00 \\
\hline $\mathrm{Sc}$ & 14.00 & 13.00 & 25.00 & 19.00 & - & 10.00 & 19.00 & - & 19.00 & 3.70 & 15.00 \\
\hline Sr & 290.00 & 300.00 & 710.00 & 18.00 & 131.00 & 200.00 & 118.00 & - & 150.00 & 66.00 & 230.00 \\
\hline Th & 11.00 & 12.00 & - & 5.00 & 15.00 & - & - & - & 17.00 & 4.10 & 13.00 \\
\hline U & 3.50 & 3.00 & - & 1.00 & 14.00 & - & - & - & - & - & - \\
\hline V & 95.00 & 130.00 & 117.00 & 120.00 & 215.00 & 150.00 & 127.00 & 248.00 & 240.00 & 10.00 & 330.00 \\
\hline $\mathrm{Zn}$ & 60.00 & 95.00 & 165.00 & 165.00 & 211.00 & 300.00 & 120.00 & 145.00 & 350.00 & 38.00 & 530.00 \\
\hline $\mathrm{Zr}$ & 160.00 & 160.00 & - & 150.00 & 139.00 & 70.00 & - & - & - & - & - \\
\hline $\mathrm{Y}$ & 34.00 & 35.00 & 150.00 & 9.00 & 35.00 & 30.00 & 27.00 & - & 16.00 & 12.00 & 20.00 \\
\hline $\mathrm{La}$ & 44.00 & 20.00 & - & 115.00 & 53.00 & 30.00 & 50.00 & - & 40.00 & 12.00 & 36.00 \\
\hline Mo & 1.00 & 2.60 & 10.00 & 27.00 & 38.00 & 10.00 & $<4.00$ & 18.00 & 7.50 & 1.40 & 7.00 \\
\hline
\end{tabular}

Note: Dashes indicate no analysis. Sample identification by column number:

1. Average upper continental crust (Wedepohl, 1971).

2. Average shale (Turekian, 1972).

3. Average Pacific pelagic clay (Bischoff et al., 1979)

4. Average deep-sea clay (Chester and Aston, 1976).

5. Average upper Devonian black shale of Appalachian Basin, eastern U.S. (data of Leventhal, 1980; Leventhal et al., 1981; Leventhal and Hosterman, 1982; and Leventhal et al., 1984).

6. Average black shale (median of 20 data sets, Vine and Tourtelot, 1970).

7. Red clay, Hatteras Abyssal Plain, core V26-157 (average of 7 analyses).

8. Average Upper Cretaceous multicolored claystone, North American Basin, DSDP Site 105 (Lancelot et al., 1972).

9. Average Upper Cretaceous multicolored claystone, North American Basin, lithologic Unit III, DSDP Site 603 (this chapter).

10. Average Eocene radiolarian claystone, lithologic Unit II, DSDP Site 603, North American Basin (this chapter).

11. Average mid-Cretaceous black claystone, lithologic Unit IV, DSDP Site 603, North American Basin (this chapter).

riched only in H-rich organic matter; and because we have found that black shales from other localities often show a correlation between concentrations of some trace transition elements and values of both $\mathrm{HI}$ and $\mathrm{OC}$, we reasoned that there might be a correlation between $\mathrm{HI}$ or percent $\mathrm{OC}$ and concentrations of some elements in the samples from Site 603. Correlation coefficients between $\mathrm{Fe}_{2} \mathrm{O}_{3}, \mathrm{MnO}$, T-N, T-S, OC, and several selected trace transition elements in black claystone samples from Site 603 are given in Table 13; they show that in general there are few significant correlations between trace-element concentrations and $\mathrm{OC}$, although there are significant correlations among the trace elements. Concentrations of $\mathrm{V}$ and $\mathrm{Zn}$ do correlate well with OC concentration. Scatter plots of ppm V versus HI, ppm V versus percent $\mathrm{OC}$, and ppm $\mathrm{Zn}$ versus percent $\mathrm{OC}$ are given in Figure 23. These plots show that a few samples with $\mathrm{HI}$ values greater than about 150 and $\mathrm{OC}$ concentrations greater than about $3.5 \%$ have concentrations of $\mathrm{V}$ and $\mathrm{Zn}$ that would be warrant terming them metal-rich according to the 90th-percentile limits of Vine and Tourte- lot (1970; Fig. 22). In other words, those samples of black claystone from the upper Cenomanian part of the section that contain the most well-preserved marine organic matter also are the most metal-rich.

Holland (1984) concluded that enrichment of trace elements in carbonaceous shales was roughly proportional to the OC content. Eugster (1985), on the other hand, pointed out that a high OC concentration does not necessarily imply a high concentration of trace elements. Figure 23 shows that, for the black and green claystones of lithologic Unit IV in Hole 603B, there is not a particularly good correlation between metal enrichment and OC content. For many other examples of OC-rich strata we have found the following relationships: (1) the most OC-rich beds usually tend to be enriched in several trace transition elements; (2) different trace elements may be enriched in different deposits; and (3) the degree of enrichment is not the same (relative to OC content) in every deposit. For example, in black shale samples from the Mowry Shale of the Cretaceous Western Interior Seaway of the U.S., we find that concentrations of $\mathrm{Zn}, \mathrm{V}$, 
Table 12 (continued).

\begin{tabular}{|c|c|c|c|c|c|c|c|c|c|c|}
\hline $\begin{array}{c}12 \\
\text { Site } 603 \\
\text { grn. claystone }\end{array}$ & $\begin{array}{c}13 \\
\text { Site } 603 \\
\text { red claystone }\end{array}$ & $\begin{array}{c}14 \\
\text { Site } 530 \\
\text { blk. claystone }\end{array}$ & $\begin{array}{c}15 \\
\text { Site } 530 \\
\text { grn. claystone }\end{array}$ & $\begin{array}{c}16 \\
\text { Site } 530 \\
\text { red claystone }\end{array}$ & $\begin{array}{c}17 \\
\text { Site } 367 \\
\text { blk. shale }\end{array}$ & $\begin{array}{c}18 \\
\text { Site } 368 \\
\text { blk. shale }\end{array}$ & $\begin{array}{c}19 \\
\text { Site } 367 \\
\text { grn. claystone }\end{array}$ & $\begin{array}{c}20 \\
\text { Site } 367 \\
\text { red claystone }\end{array}$ & $\begin{array}{c}21 \\
\text { Site } 367 \\
\text { grn. claystone }\end{array}$ & $\begin{array}{c}22 \\
\text { Site } 367 \\
\text { blk. shale }\end{array}$ \\
\hline- & - & 57.20 & 63.60 & 58.70 & - & - & 54.80 & 52.20 & 47.20 & 38.50 \\
\hline 18.70 & 17.60 & 11.90 & 12.20 & 12.60 & 9.70 & 13.50 & 12.00 & 12.10 & 9.60 & 7.00 \\
\hline 6.06 & 8.46 & 8.61 & 7.90 & 10.00 & 5.18 & 6.00 & 4.13 & 5.66 & 3.96 & 3.33 \\
\hline 2.03 & 1.78 & 2.77 & 3.14 & 3.62 & 1.54 & 2.77 & 1.18 & 1.19 & 1.91 & 1.38 \\
\hline 0.48 & 0.45 & 3.60 & 6.72 & 5.64 & 4.23 & 3.94 & 0.59 & 0.53 & 2.96 & 1.58 \\
\hline 1.39 & 1.35 & 1.40 & 1.43 & 1.48 & 0.97 & 1.21 & 0.61 & 0.61 & 0.62 & 0.50 \\
\hline 2.77 & 2.82 & 3.19 & 3.25 & 3.46 & 1.55 & 2.39 & 2.68 & 3.18 & 2.68 & 2.02 \\
\hline 0.86 & 0.84 & 1.12 & 1.17 & 1.24 & 0.41 & 0.61 & 0.56 & 0.54 & 0.32 & 0.17 \\
\hline 0.11 & 0.16 & 0.19 & 0.19 & 0.18 & 0.36 & 0.31 & - & - & - & - \\
\hline 0.04 & 0.22 & 0.08 & 0.29 & 0.24 & 0.03 & 0.05 & 0.04 & 0.07 & 0.06 & 0.04 \\
\hline- & - & 48.00 & 40.00 & 56.00 & 38.00 & 18.00 & - & - & - & - \\
\hline- & - & 137.00 & 110.00 & 160.00 & - & - & 140.00 & 146.00 & 120.00 & 120.00 \\
\hline 420.00 & 360.00 & 1100.00 & 790.00 & 1200.00 & 600.00 & 650.00 & 460.00 & 420.00 & 630.00 & 580.00 \\
\hline- & - & 28.00 & 22.00 & 15.00 & 11.00 & 18.00 & - & - & - & - \\
\hline 120.00 & 18.00 & 69.00 & 29.00 & 50.00 & 14.00 & 17.00 & 14.00 & 12.00 & 13.00 & 13.00 \\
\hline 130.00 & 110.00 & 22.00 & 96.00 & 130.00 & 258.00 & 210.00 & 120.00 & 110.00 & 98.00 & 110.00 \\
\hline 91.00 & 46.00 & 170.00 & 85.00 & 97.00 & 178.00 & 142.00 & 64.00 & 36.00 & 98.00 & 140.00 \\
\hline 25.00 & 24.00 & 59.00 & 73.00 & 68.00 & 15.00 & 20.00 & 19.00 & 20.00 & 19.00 & 16.00 \\
\hline 72.00 & 68.00 & 43.00 & 46.00 & 33.00 & 32.00 & 42.00 & - & - & - & - \\
\hline 170.00 & 59.00 & 180.00 & 72.00 & 93.00 & 220.00 & 210.00 & 41.00 & 40.00 & 81.00 & 98.00 \\
\hline 26.00 & 14.00 & 27.00 & 64.00 & 46.00 & 12.00 & 14.00 & 12.00 & 9.00 & 13.00 & 13.00 \\
\hline 17.00 & 18.00 & 22.00 & 24.00 & 22.00 & 12.00 & 14.00 & 14.00 & 14.00 & 12.00 & 11.00 \\
\hline 200.00 & 180.00 & 190.00 & 230.00 & 220.00 & 210.00 & 180.00 & 150.00 & 150.00 & 210.00 & 170.00 \\
\hline 15.00 & 16.00 & 33.00 & 29.00 & 38.00 & 7.00 & 13.00 & - & - & - & - \\
\hline- & - & 450.00 & 320.00 & 580.00 & - & - & - & - & - & - \\
\hline 140.00 & 120.00 & 690.00 & 200.00 & 260.00 & 1180.00 & 1210.00 & 100.00 & 110.00 & 340.00 & 410.00 \\
\hline 150.00 & 94.00 & 780.00 & 130.00 & 130.00 & 880.00 & 1040.00 & 82.00 & 89.00 & 1010.00 & 680.00 \\
\hline- & - & 180.00 & 190.00 & 170.00 & - & - & 230.00 & 190.00 & 126.00 & 140.00 \\
\hline 18.00 & 22.00 & 35.00 & 33.00 & 30.00 & 30.00 & 42.00 & 22.00 & 20.00 & 26.00 & 29.00 \\
\hline 40.00 & 41.00 & 34.00 & 37.00 & 34.00 & 29.00 & 49.00 & 31.00 & 32.00 & 29.00 & 26.00 \\
\hline 8.00 & $<4.00$ & 25.00 & 9.00 & 8.00 & 97.00 & 125.00 & 2.00 & 2.00 & 32.00 & 40.00 \\
\hline
\end{tabular}

12. Average mid-Cretaceous green claystone, lithologic Unit IV, DSDP Site 603, North American Basin (this chapter).

13. Average mid-Cretaceous red claystone, lithologic Unit IV, DSDP Site 603, North American Basin (this chapter).

14. Average mid-Cretaceous black claystone, Angola Basin (Dean and Parduhn, 1984).

15. Average mid-Cretaceous green claystone, Angola Basin (Dean and Parduhn, 1984).

16. Average mid-Cretaceous red claystone, Angola Basin (Dean and Parduhn, 1984)

17. Average mid-Cretaceous black shale, Cape Verde Basin, DSDP Hole 367, Cores 18-22 (Dean and Arthur, unpublished data).

18. Average mid-Cretaceous black shale, Cape Verde Rise, DSDP Hole 368, Cores 58-63 (Dean and Arthur, unpublished data).

19. Average Upper Cretaceous green claystone, Cape Verde Basin, DSDP Hole 367, Cores 15 and 16 (Dean and Gardner, 1982).

20. Average Upper Cretaceous red claystone, Cape Verde Basin, DSDP Hole 367, Cores 15 and 16 (Dean and Gardner, 1982).

21. Average mid-Cretaceous green claystone, Cape Verde Basin, DSDP Hole 367, Cores 17 and 19 (Dean and Gardner, 1982).

22. Average mid-Cretaceous black shale, Cape Verde Basin, DSDP Hole 367, Cores 17 and 19 (Dean and Gardner, 1982).

and $\mathrm{Ni}$ are highly correlated with $\mathrm{OC}$ content (up to $4.4 \%$ ), but the element concentrations are mostly $<100$ ppm. In black shales from DSDP Site 530 in the Angola Basin, the concentrations of $\mathrm{Zn}, \mathrm{V}$, and $\mathrm{Ni}$ also are highly correlated with OC content (up to $5 \%$ ), but concentrations of these elements usually are several hundred parts per million, and concentrations of $\mathrm{V}$ and $\mathrm{Zn}$ commonly are $>1000 \mathrm{ppm}$ (Dean and Parduhn, 1984). We have found that $\mathrm{Zn}, \mathrm{V}$, and $\mathrm{Ni}$ are the three trace transition elements most commonly enriched in black shales, but other elements also may be enriched, and different elements are enriched in different deposits. Consequently, the concentrations of trace elements are not simply related to either amount of organic matter (percent OC) or type of organic matter (e.g., HI).

In addition to concentrations of $\mathrm{V}$ and $\mathrm{Zn}$ being somewhat higher in the black claystones than in the red and green claystones, Figure 21 shows some other differences in element concentrations between red, green, and black claystones in lithologic Unit IV. Concentrations of Cr, $\mathrm{Cu}, \mathrm{Co}, \mathrm{Mo}$, and $\mathrm{Pb}$, are higher in both green and black claystones than in red claystones. All of these elevated concentrations of trace transition elements undoubtedly are related to the formation of metal sulfides during suboxic or anoxic early diagenesis within both green and black lithologies.

Another consequence of reduction in the green and black lithologies is the much lower concentrations of $\mathrm{Mn}$ and $\mathrm{Fe}$ in these two lithologies than in the red claystones (Fig. 21A). Redox separation of Mn is well known in both ancient and Holocene sedimentary sequences (e.g., Lynn and Bonatti, 1965; Li et al., 1969; Bender, 1971; Froelich et al., 1979; Gardner et al., 1982; Dean and Parduhn, 1984). This is because Mn, once reduced to $\mathrm{Mn}(\mathrm{II})$ in anoxic pore waters, diffuses out of the sediments and does not usually form divalent compounds. The exception to this is the formation of rhodochrosite $\left(\mathrm{MnCO}_{3}\right)$ if the concentration of carbonate is sufficiently high (Suess, 1979; Pederson and Price, 1982). Iron, on there other hand, is more conservative, being preserved as ferric oxides, hydroxides, and other Fe(IV) compounds in oxidized sediments, and forming ferrous sul- 

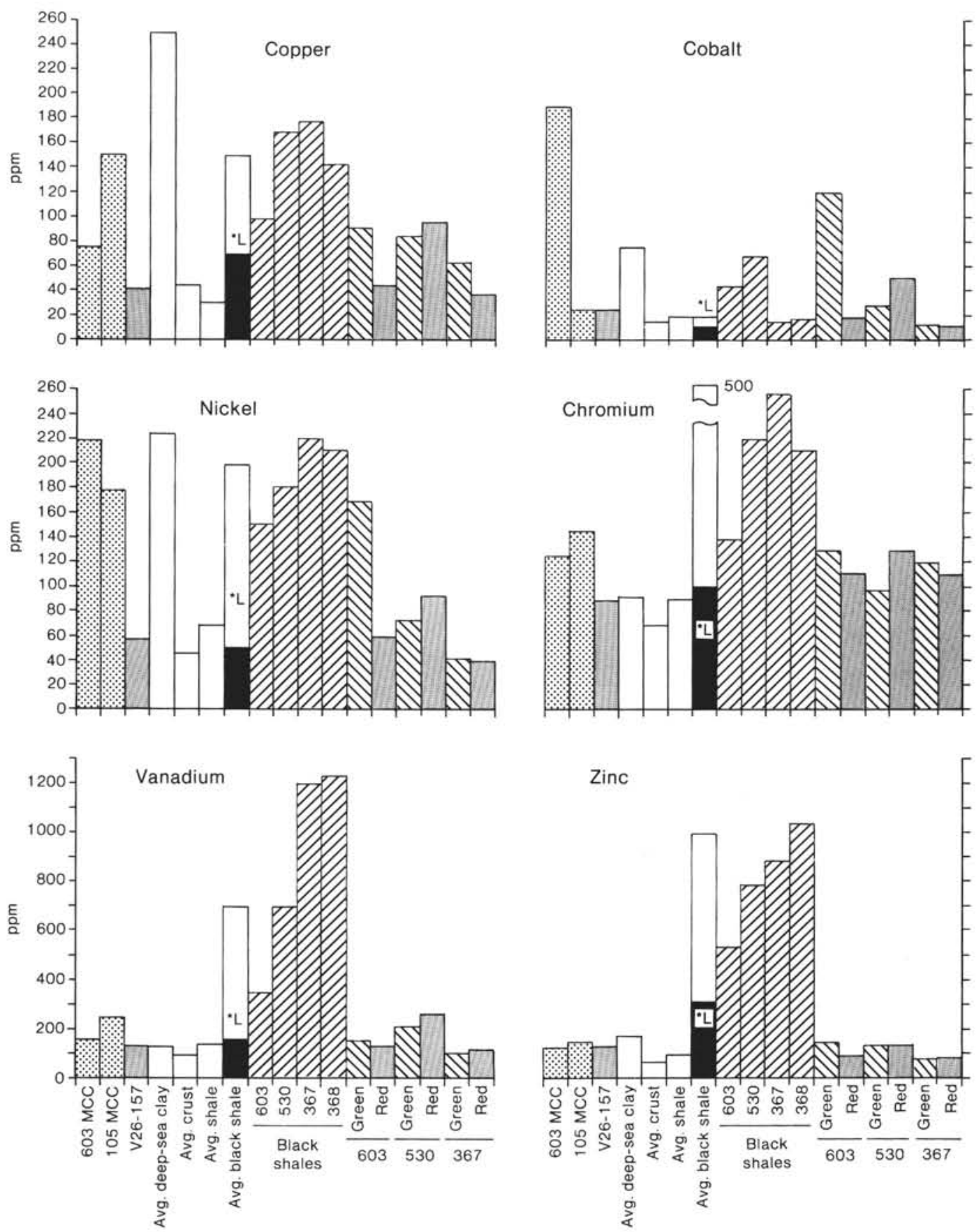

Figure 22. Histograms of average concentrations of copper, cobalt, nickel, chromium, vanadium, and zinc in selected groups of samples. 603MCC: Upper Cretaceous multicolored claystones from lithologic Unit III, Hole 603 (Table 3). 105MCC: Upper Cretaceous multicolored claystones from Site 105 (Lancelot et al., 1972). V26-157: average of seven analyses of abyssal red clay from Lamont-Doherty core V26-157 from the Hatteras Abyssal Plain (Table 12). Avg. deep-sea clay: average deep-sea clay, carbonate-free (Chester and Aston, 1976; Table 12). Avg. crust: average upper continental crust (Wedepohl, 1971; Table 12). Avg. shale: average shale (Turekian, 1972). Avg. black shale: lower bar (black) is the median of medians of 20 data sets of analyses of black shale samples (Vine and Tourtelot, 1970); upper bar (white) is the 90th percentile of the Vine and Tourtelot (1970) samples, a value they consider as the lower limit of metal-rich black shales; point marked ${ }^{*} \mathrm{~L}$ is the arithmetic mean concentration in up to 400 samples of upper Devonian black shales from the Appalachian Basin, reported by Leventhal and colleagues (Leventhal, 1980; Leventhal et al., 1981, 1984; Leventhal and Hosterman, 1982). Black Shales 603, 530, 367, 368: average concentrations in mid-Cretaceous black shales from DSDP Sites 603 (Table 12), 530 (Dean and Parduhn, 1984), 367 (Table 12), and 368 (Table 12). 603, green, red: average concentrations of green and red claystones from lithologic Unit IV, Hole 603B (Table 12). 530, green, red: average concentrations in mid-Cretaceous green and red claystones from Hole 530A (Dean and Parduhn, 1984; Table 12). 367, green, red: average concentrations in mid-Cretaceous green and red claystones from Hole 367 (Dean and Gardner, 1982; Table 12). 
Table 13. Matrix of correlation coefficients between concentrations of major-element oxides and trace elements in red, green, and black claystones from lithologic Unit IV, Hole 603B.

\begin{tabular}{|c|c|c|c|c|c|c|c|c|c|c|c|c|}
\hline & $\begin{array}{c}\mathrm{Fe}_{2} \mathrm{O}_{3} \\
(\%)\end{array}$ & $\begin{array}{c}\mathrm{P}_{2} \mathrm{O}_{5} \\
(\%)\end{array}$ & $\begin{array}{c}\mathrm{MnO} \\
(\%)\end{array}$ & $\begin{array}{c}\text { Co } \\
\text { (ppm) }\end{array}$ & $\underset{(\mathrm{ppm})}{\mathrm{Cr}}$ & $\underset{(\mathrm{ppm})}{\mathrm{Cu}}$ & $\begin{array}{c}\mathrm{Ni} \\
(\mathrm{ppm})\end{array}$ & $\begin{array}{c}\mathrm{Pb} \\
(\mathrm{ppm})\end{array}$ & $\begin{array}{c}\mathrm{V} \\
(\mathrm{ppm})\end{array}$ & $\underset{(\mathrm{ppm})}{\mathrm{Zn}}$ & $\begin{array}{c}N \\
(\%)\end{array}$ & $\begin{array}{c}\text { OC-MA } \\
(\%)\end{array}$ \\
\hline $\mathrm{Fe}_{2} \mathrm{O}_{3}(\%)$ & 1.0000 & -0.1198 & -0.0095 & -0.0579 & -0.1262 & -0.1629 & 0.1715 & 0.5640 & -0.0677 & -0.0783 & -0.0172 & -0.0183 \\
\hline $\mathrm{P}_{2} \mathrm{O}_{5}(\%)$ & -0.1198 & 1.0000 & 0.3310 & -0.1960 & -0.0006 & 0.1619 & -0.1839 & -0.2202 & 0.3057 & 0.1802 & 0.3502 & 0.2731 \\
\hline $\mathrm{MnO}(\%)$ & -0.0095 & 0.3310 & 1.0000 & -0.0673 & -0.1087 & -0.0151 & -0.1110 & -0.1290 & -0.0691 & -0.0937 & -0.1299 & -0.1910 \\
\hline Co (ppm) & -0.0579 & -0.1960 & -0.0673 & 1.0000 & 0.0858 & 0.1901 & 0.8732 & 0.0969 & 0.0737 & -0.0004 & -0.0422 & -0.1202 \\
\hline $\mathrm{Cr}$ (ppm) & -0.1262 & -0.0006 & -0.1087 & 0.0858 & 1.0000 & 0.2963 & 0.1162 & 0.3731 & 0.5001 & 0.4834 & 0.4794 & 0.4700 \\
\hline $\mathrm{Cu}$ (ppm) & -0.1629 & 0.1619 & -0.0151 & 0.1901 & 0.2963 & 1.0000 & 0.0663 & 0.3318 & 0.4804 & 0.4657 & 0.2807 & 0.2525 \\
\hline $\mathrm{Ni}$ (ppm) & 0.1715 & -0.1839 & -0.1110 & 0.8732 & 0.1162 & 0.0663 & 1.0000 & 0.2401 & 0.1431 & 0.0277 & 0.1176 & 0.0642 \\
\hline $\mathrm{Pb}$ (ppm) & 0.5640 & -0.2202 & -0.1290 & 0.0969 & 0.3731 & 0.3318 & 0.2401 & 1.0000 & 0.4408 & 0.5163 & 0.3118 & 0.3213 \\
\hline $\mathrm{V}$ (ppm) & -0.0677 & 0.3057 & -0.0691 & 0.0737 & 0.5001 & 0.4804 & 0.1431 & 0.4408 & 1.0000 & 0.8444 & 0.8145 & 0.7634 \\
\hline $\mathrm{Zn}$ (ppm) & -0.0783 & 0.1802 & -0.0937 & -0.0004 & 0.4834 & 0.4657 & 0.0277 & 0.5163 & 0.8444 & 1.0000 & 0.6304 & 0.5831 \\
\hline$N(\%)$ & -0.0172 & 0.3502 & -0.1299 & -0.0422 & 0.4794 & 0.2807 & 0.1176 & 0.3118 & 0.8145 & 0.6304 & 1.0000 & 0.9807 \\
\hline OC-MA $(\%)$ & -0.0183 & 0.2731 & -0.1910 & -0.1202 & 0.4700 & 0.2525 & 0.0642 & 0.3213 & 0.7634 & 0.5831 & 0.9807 & 1.0000 \\
\hline
\end{tabular}
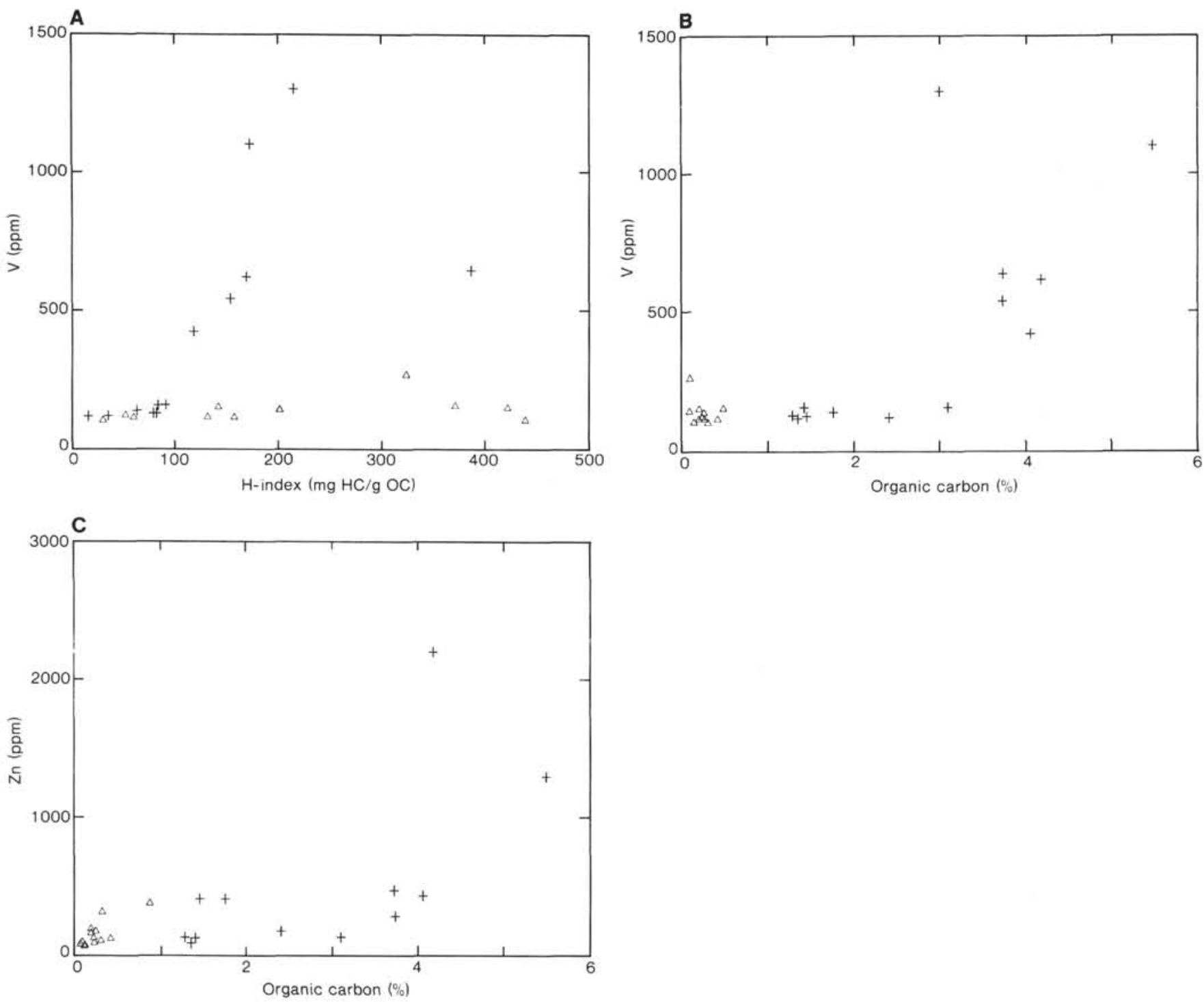

Figure 23. Plots of (A) Rock-Eval hydrogen index versus ppm V; (B) percent organic carbon versus ppm V; and (C) percent organic carbon versus $\mathrm{ppm} \mathrm{Zn}$. All for samples of green and black claystones from lithologic Unit IV, Hole 603B. Symbol designations are the same as in Figure 18. 
fides and (or) carbonates when reduced to $\mathrm{Fe}(\mathrm{II})$ in suboxic or anoxic pore waters. The important feature of trace metal concentrations in the black claystones of Hole $603 \mathrm{~B}$ is that concentrations of most of the redox-sensitive transition metals $(\mathrm{V}, \mathrm{Zn}, \mathrm{Ni}, \mathrm{Cu}$, and $\mathrm{Cr}$ ) are lower than in other Atlantic black claystone or shale sequences that we have analyzed (Fig. 22, Table 12).

\section{Q-Mode Factor Analysis}

We used Q-mode factor analysis to determine if there were any other significant geochemical differences among the claystones of lithologic Unit IV. After experimenting with several different numbers and orientations of factor axes, we chose a 4-factor, orthogonal (varimax) factor model that explained $93 \%$ of the variance in the data after they were normalized to percent of range for each element or oxide. Table 14 lists the correlations between the input chemical variables (percent or ppm oxide or element) and the four composite chemical variables computed by the Q-mode (factor loadings). Factors 1 and 2 are negative and positive organic factors, respectively. Factor 1 expresses a weak negative association between the organic variables (OC, T-S, and T-N) and several terrigenous clastic variables $(\mathrm{Y}, \mathrm{Ti}$, and $\mathrm{K})$. Factor 2 expresses the strong correlation among the organic variables (Table 13; Fig. 19) and weak positive associations

Table 14. Correlation coefficients for Q-mode factor loadings (factors 1-4) versus concentrations of major-element oxides and trace elements in red, green and black claystone samples from lithologic Unit IV, Hole 603B.

\begin{tabular}{|c|c|c|c|c|}
\hline Variable & Factor 1 & Factor 2 & Factor 3 & Factor 4 \\
\hline $\mathrm{Al}_{2} \mathrm{O}_{3}(\%)$ & 0.1797 & -0.5347 & 0.7073 & 0.2251 \\
\hline $\mathrm{Fe}_{2} \mathrm{O}_{3}(\%)$ & -0.2837 & 0.0015 & -0.0440 & 0.1225 \\
\hline $\operatorname{MgO}(\%)$ & 0.0460 & -0.1069 & -0.1896 & 0.6947 \\
\hline $\mathrm{CaO}(\%)$ & -0.0679 & 0.5163 & -0.6219 & 0.4990 \\
\hline $\mathrm{Na}_{2} \mathrm{O}(\%)$ & -0.0773 & 0.3806 & -0.6685 & 0.5722 \\
\hline $\mathrm{K}_{2} \mathrm{O}(\%)$ & 0.3949 & -0.0492 & 0.2671 & 0.0493 \\
\hline $\mathrm{TiO}_{2}(\%)$ & 0.5095 & -0.5100 & 0.6530 & -0.2397 \\
\hline $\mathrm{P}_{2} \mathrm{O}_{5}(\%)$ & 0.3996 & 0.3041 & -0.3879 & -0.3903 \\
\hline $\mathrm{MnO}(\%)$ & 0.1772 & -0.2625 & 0.0857 & -0.2450 \\
\hline Co (ppm) & -0.2199 & -0.2120 & 0.4794 & -0.3158 \\
\hline $\mathrm{Cr}(\mathrm{ppm})$ & -0.4087 & 0.4358 & 0.1995 & -0.1160 \\
\hline $\mathrm{Cu}$ (ppm) & -0.1360 & 0.3165 & 0.0075 & -0.3421 \\
\hline $\mathrm{Ni}(\mathrm{ppm})$ & -0.3983 & -0.0366 & 0.3386 & -0.2668 \\
\hline $\mathrm{Pb}$ (ppm) & -0.5817 & 0.2925 & 0.0701 & 0.1717 \\
\hline$V(p p m)$ & -0.4887 & 0.6517 & -0.2011 & -0.4831 \\
\hline $\mathrm{Zn}$ (ppm) & -0.3738 & 0.4817 & -0.0735 & -0.2884 \\
\hline $\mathrm{Li}(\mathrm{ppm})$ & 0.0380 & -0.5512 & 0.6232 & 0.2266 \\
\hline N-MA $(\%)^{\mathrm{a}}$ & -0.5967 & 0.8651 & -0.3265 & -0.3771 \\
\hline Total S $(\%)$ & -0.6033 & 0.8601 & -0.4618 & -0.0222 \\
\hline OC-MA $(\%)^{\mathrm{b}}$ & -0.6355 & 0.9085 & -0.3970 & -0.2725 \\
\hline $\mathrm{Sc}(\mathrm{ppm})$ & 0.4317 & -0.4334 & 0.7042 & -0.4127 \\
\hline Sc (ppm) & 0.4317 & -0.4334 & 0.7042 & -0.4127 \\
\hline $\mathrm{Sr}(\mathrm{ppm})$ & -0.3094 & 0.6490 & -0.7816 & 0.2603 \\
\hline Y (ppm) & 0.3464 & 0.3899 & -0.5199 & -0.2118 \\
\hline $\mathrm{Ce}$ (ppm) & 0.0986 & -0.4175 & -0.0267 & 0.4629 \\
\hline $\mathrm{Ga}(\mathrm{ppm})$ & 0.2185 & -0.4541 & 0.6498 & 0.1727 \\
\hline $\mathrm{Yb}(\mathrm{ppm})$ & 0.6049 & -0.1280 & 0.0062 & -0.4072 \\
\hline Nd (ppm) & 0.5420 & -0.5390 & 0.2170 & -0.0730 \\
\hline Factor 1 & 1.0000 & -0.5193 & 0.0726 & 0.0029 \\
\hline Factor 2 & -0.5193 & 1.0000 & -0.6017 & -0.1514 \\
\hline Factor 3 & 0.0726 & -0.6017 & 1.0000 & -0.1283 \\
\hline Factor 4 & 0.0029 & -0.1514 & -0.1283 & 1.0000 \\
\hline
\end{tabular}

between the organic variables and carbonate variables $(\mathrm{Ca}$ and $\mathrm{Sr}$ ) and several trace transition elements ( $\mathrm{V}$ and $\mathrm{Zn})$. In other words factor 1 claystone samples have relatively low concentrations of OC, T-N, and T-S and relatively high concentrations of $\mathrm{Y}, \mathrm{Ti}$, and $\mathrm{K}$. Factor 2 claystone samples, in contrast, have relatively high organic contents, minor amounts of carbonate, and high concentrations of $\mathrm{V}$ and $\mathrm{Zn}$.

We expected that most factor 1 samples would be red claystone and most factor 2 samples would be black claystone, with some number of green claystone samples in both factors as intermediate types. Table 15 shows that all red claystone samples do have high loadings for factor 1 , but many samples of green and black claystone al-

Table 15. Factor loadings for each of the four factors used in the Qmode model of the chemical compositions of red, green, and black claystone samples from lithologic Unit IV, Hole 603B. Communalities (COMM) for each sample computed for the 4-factor varimax model, as well as the variance and cumulative variance in the transformed data explained by each of the four factors, also are given.

\begin{tabular}{|c|c|c|c|c|c|c|}
\hline $\begin{array}{l}\text { Core-Section, } \\
\text { interval }(\mathrm{cm})\end{array}$ & Comm. & $\begin{array}{c}\text { Factor } \\
1\end{array}$ & $\begin{array}{l}\text { Factor } \\
2\end{array}$ & $\begin{array}{c}\text { Factor } \\
3\end{array}$ & $\begin{array}{c}\text { Factor } \\
4\end{array}$ & Color \\
\hline $28-1,25-28$ & 0.8498 & 0.4309 & 0.2057 & -0.7624 & -0.2013 & Green \\
\hline $28-3,67-70$ & 0.9537 & 0.6571 & 0.2630 & -0.6042 & -0.2960 & Green \\
\hline $28-3,129-132$ & 0.7875 & 0.6514 & 0.2339 & -0.4999 & -0.2420 & Red \\
\hline $28, \mathrm{CC}(5-8)$ & 0.9136 & 0.5452 & 0.3587 & -0.6748 & -0.1798 & Black \\
\hline $29-1,142-144$ & 0.9568 & 0.5251 & 0.2625 & -0.7366 & -0.2637 & Green \\
\hline $29-4,103-105$ & 0.8884 & 0.6579 & 0.2098 & -0.6179 & -0.1727 & Red \\
\hline $29.4,105-107$ & 0.9097 & 0.7273 & 0.1895 & -0.5526 & -0.1986 & Red \\
\hline $32-1,45-47$ & 0.9636 & 0.7480 & 0.2038 & -0.5617 & -0.2172 & Red \\
\hline $32-1,59-61$ & 0.8824 & 0.4940 & 0.2665 & -0.7311 & -0.1814 & Green \\
\hline $32-1,61-63$ & 0.8562 & 0.2550 & 0.5905 & -0.6583 & -0.0956 & Green \\
\hline $32-1,76-78$ & 0.8618 & 0.4431 & 0.1581 & -0.7792 & -0.1825 & Green \\
\hline $32-1,115-117$ & 0.9630 & 0.7039 & 0.2132 & -0.5934 & -0.2648 & Red \\
\hline $34-2,35-40$ & 0.8849 & -0.0494 & 0.9302 & -0.1255 & -0.0389 & lack \\
\hline $35-1,23-25$ & 0.7805 & 0.3438 & 0.16 & -0.2084 & 0.7700 & ireen \\
\hline $35-1,30-32$ & 0.9658 & 0.51 & 0.39 & -0.5802 & -0.4 & Black \\
\hline $35-1,49-51$ & 0.9370 & 0.4904 & 0.5795 & -0.4549 & -0.3921 & Black \\
\hline $35-2,18-20$ & 0.9433 & 0.3289 & 0.8539 & -0.1832 & -0.2692 & Black \\
\hline $35-2,47-48$ & 0.8736 & 0.5171 & 0.5478 & -0.2761 & -0.4795 & Black \\
\hline $35-2,128-130$ & 0.9340 & 0.6465 & 0.4164 & -0.3293 & -0.4840 & Green \\
\hline $36-1,115-116$ & 0.9812 & 0.7293 & 0.3214 & -0.4899 & -0.3256 & Green \\
\hline $36-1,118-119$ & 0.9057 & 0.5019 & 0.3189 & -0.6281 & -0.3970 & Black \\
\hline $36-1,121-122$ & 0.9857 & 0.7307 & 0.3203 & -0.4896 & -0.3308 & Green \\
\hline $36-3,8-11$ & 0.9785 & 0.6328 & 0.36 & -0.4830 & -0.4572 & Green \\
\hline $36-3,13-16$ & 0.9810 & 0.6379 & 0.3240 & -0.4713 & -0.4970 & Green \\
\hline $36-3,17-19$ & 0.9628 & 0.4774 & 0.3829 & -0.6481 & -0.4101 & Black \\
\hline $36-3,21-23$ & 0.9743 & 0.5180 & 0.3832 & -0.6139 & -0.4268 & Green \\
\hline $36-3,27-29$ & 0.9593 & 0.5181 & 0.4019 & -0.5923 & -0.4226 & Black \\
\hline $36-3,35-37$ & 0.9760 & 0.5607 & 0.5319 & -0.4187 & -0.4510 & Black \\
\hline $36-3,49-50$ & 0.9323 & 0.3979 & 0.7565 & -0.3723 & -0.2513 & Black \\
\hline $36-3,57-59$ & 0.9639 & 0.5076 & 0.7348 & -0.2781 & -0.2983 & Black \\
\hline $36-3,70-72$ & 0.9756 & 0.5451 & 0.4054 & -0.5618 & -0.4456 & Black \\
\hline $37-1,30-32$ & 0.6167 & 0.1130 & 0.3310 & -0.5164 & -0.4772 & Black \\
\hline $37-1,33-35$ & 0.9801 & 0.6101 & 0.3903 & -0.5279 & -0.4205 & Black \\
\hline $37-5,104-106$ & 0.9285 & 0.5816 & 0.4225 & -0.4300 & -0.4763 & Green \\
\hline 37-5. $107-109$ & 0.9830 & 0.6147 & 0.5311 & -0.4274 & -0.3748 & Black \\
\hline $37-5,111-113$ & 0.9770 & 0.5202 & 0.4294 & -0.5470 & -0.4720 & Black \\
\hline $38-1,50-52$ & 0.9566 & 0.7379 & 0.3179 & -0.4380 & -0.3451 & Green \\
\hline $38-1,146-149$ & 0.9068 & 0.4733 & 0.7827 & -0.2375 & -0.1172 & Black \\
\hline $38-2,8-10$ & 0.9708 & 0.5909 & 0.3009 & -0.5841 & -0.4358 & Green \\
\hline $38-2,18-21$ & 0.9679 & 0.5460 & 0.5791 & -0.3946 & -0.4227 & Black \\
\hline $38-2,22-25$ & 0.9830 & 0.6279 & 0.4759 & -0.4852 & -0.3 & Black \\
\hline $38-2,25-28$ & 0.9767 & 0.69 & 0.3 & -0.4419 & -0.3944 & Green \\
\hline $38-2,52-54$ & 0.9681 & 0.7131 & 0.3285 & -0.5023 & -0.3154 & Green \\
\hline $38-3,50-52$ & 0.9322 & 0.7693 & 0.3743 & -0.3824 & -0.2324 & Green \\
\hline $38-4,50-52$ & 0.9729 & 0.8010 & 0.3028 & -0.3737 & -0.3161 & Red \\
\hline $38-5,52-54$ & 0.8920 & 0.5235 & 0.2961 & -0.5650 & -0.4594 & Green \\
\hline $43-2,30-32$ & 0.9737 & 0.8571 & 0.3244 & -0.2939 & -0.2177 & Red \\
\hline $43-2,54-56$ & 0.9741 & 0.8463 & 0.3219 & -0.3179 & -0.2307 & Red \\
\hline $43-2,111-114$ & 0.9645 & 0.7945 & 0.2949 & -0.3840 & -0.3143 & Red \\
\hline $43-3,135-137$ & 0.9415 & 0.6828 & 0.2630 & -0.5510 & -0.3202 & Green \\
\hline $43-4,15-18$ & 0.9095 & 0.6792 & 0.1854 & -0.5815 & -0.2751 & Green \\
\hline \multirow[t]{3}{*}{$43-6,25-27$} & 0.9610 & 0.7322 & 0.2835 & -0.5282 & -0.2557 & Green \\
\hline & Variance & 35.968 & 18.162 & 26.212 & 12.771 & \\
\hline & um. Var. & 35.968 & 54.130 & 80.342 & 93.113 & \\
\hline
\end{tabular}


so have high loadings for factor 1 . All samples having high loadings for factor 2 are black claystones, but only 11 of the 20 samples visually classified as black claystone have the geochemical characteristics of black claystone as defined by factor 2 in the Q-mode model. Most of these 11 samples are from the Cenomanian interval that has a larger contribution of pelagic marine organic matter (Table 15).

Factor 3 is another terrigenous clastic factor, and groups those claystone samples, regardless of color, that contain relatively high concentrations of $\mathrm{Al}, \mathrm{Ti}, \mathrm{Sc}, \mathrm{Li}$, and $\mathrm{Ga}$ and low concentrations of $\mathrm{Ca}, \mathrm{Na}$, and $\mathrm{Sr}$. The combination of factors 1 and 3 defines compositional characteristics of clastic material in Unit IV samples that are similar to compositional characteristics of clastic material in Unit $\mathrm{V}$ factor 1 samples also having relatively high concentrations of $\mathrm{Ti}, \mathrm{K}$, and $\mathrm{Al}$. Factor 4 claystone samples from Unit IV have relatively high concentrations of $\mathrm{Mg}, \mathrm{Na}, \mathrm{Ca}$, and $\mathrm{Ce}$, and in this regard have compositional characteristics similar to those of the high$\mathrm{Mg}$ and -REE samples of Neocomian carbonates from Unit V.

Our interpretation of the geochemical analyses of claystone samples from lithologic Unit IV, and the objective groupings produced by Q-mode factor analysis of these geochemical results, indicate that there are no clear-cut distinctions between the different-colored lithologies. We may be seeing the results of mixing of clastic material derived from two different sources (North America and Northwest Africa), together with minor amounts of hydrogenous and hydrothermal material, just as we inferred for the clastic material in the Neocomian carbonates. For example, Table 12 shows that the red, green, and black claystones from Site 367 off Northwest Africa have, on average, lower concentrations of $\mathrm{Na}$ and $\mathrm{Mg}$ than the red, green, and black claystones of lithologic Unit IV in Hole 603B. Therefore, those samples of Site 603 claystones with low loadings for factor 4 and high loadings for factor 3 may reflect a greater influx of eolian clastic material from an African source.

Another significant variable is the relative proportion of material redeposited from shallower sites of accumulation. The black claystone beds probably contain the highest proportion of redeposited terrigenous organic and inorganic material. The black beds with the most organic characteristics (factor 2 samples) also contain the highest amounts of carbonate, which would also reflect a shallow-water source.

\section{Lithologic Unit III-Multicolored Claystones}

At most DSDP sites in the North Atlantic, the midCretaceous black-shale unit is overlain by a unit of upper Cretaceous to lower Tertiary interbedded green and red clay that corresponds to lithologic Unit III at Site 603. This unit was called the Plantagenet Formation by Jansa et al. (1979), who interpreted the claystones of this unit as having been deposited in an oxygenated, pelagic deep-sea environment similar to the environments presently accumulating pelagic clays in the deep basins of the Pacific and Atlantic oceans. At Site 105 in the North American Basin, just to the southeast of Site 603, the multicolored claystones of the Plantagenet Forma- tion were found by Lancelot et al. (1972) to be enriched in several trace transition elements, especially $\mathrm{Mn}, \mathrm{Zn}$, $\mathrm{Cu}, \mathrm{Pb}, \mathrm{Cr}, \mathrm{Ni}$, and $\mathrm{V}$. Lancelot et al. suggested that this metal enrichment was from volcanic exhalations, and that these claystones were therefore analogous metal-enriched sediments associated with Red Sea hydrothermal brine deposits, or to metal-enriched basal sediments overlying basement along the East Pacific Rise. Figure 24 is a comparison of concentrations of $\mathrm{Zn}, \mathrm{Cu}, \mathrm{Cr}, \mathrm{Ni}$, and $\mathrm{V}$ in Upper Cretaceous multicolored claystones (MCCs) from western North Atlantic Sites 105, 386, and 603 and in hot-brine deposits from the Red Sea. Figure 24 shows that, relative to the Red Sea deposits, the MCCs are enriched in $\mathrm{Cr}, \mathrm{Ni}$, and $\mathrm{V}$, whereas the Red sea deposits are more enriched in $\mathrm{Zn}$ and $\mathrm{Cu}$. Note that the enrichment of transition metals at Site 105 generally is greater (in terms of number of samples at a given concentration) than at Site 603, in keeping with the somewhat higher concentrations of OC in the black shales at Site 105 (e.g., Arthur and Dean, 1986).

Comparisons with other claystones and clays from different environments (Table 12; Fig. 22) provides an even better perspective of metal enrichment in the MCCs. If the MCCs did accumulate in an oxygenated environment equivalent to present deep-sea red-clay environments, then perhaps the best comparison is between the composition of the MCCs and red clay at the top of Lamont-Doherty core V26-157 from the Hatteras Abyssal Plain (Fig. 1). The average oxide and element concentrations in this sample, given in Table 12 and Figure 22, are the arithmetic mean concentrations from seven analyses of the same sample by the analytical laboratories of the U.S.G.S. over a period of about three years; one of these seven analyses was done at the same time as the analyses of the shipboard samples from Site 603. Figure 22 shows that the MCCs from Sites 105 and 603 are enriched in $\mathrm{Ni}$ and $\mathrm{Cr}$ relative to most deep-sea clays, and that the MCCs from Site 603 are enriched in Co. The MCCs are considerably enriched in $\mathrm{Cu}$ and $\mathrm{Ni}$ compared with the V26-157 red clay, but not compared with the average deep-sea clay of Chester and Aston (1976), although we suspect that their average deep-sea clay contains a disproportionately large number of samples of red clay from the central North Pacific, which tend to be enriched in several trace transition elements, especially $\mathrm{Cu}, \mathrm{Ni}$, and Co (compare, e.g., the Chester and Aston [1976] average deep-sea clay with the average Pacific pelagic clay of Bischoff et al. [1979] in Table 12). The concentration of $\mathrm{Cr}$ in the MCCs is slightly higher than in average deepsea clays, but is similar to the $\mathrm{Cr}$ concentration in Upper Cretaceous-lower Tertiary red and green claystones at Site 367 (eastern North Atlantic; Cores 367-15 and 36716 , Table 12 ) that are stratigraphically equivalent to the MCCs in the North American Basin. The concentration of $\mathrm{Cr}$ in the MCCs also is similar to that in red and green claystones interbedded with black shales at Sites 603 and 530. Concentrations of Co are not elevated in the MCCs from Site 105, but are considerably elevated in the MCCs from Site 603 (Table 12; Fig. 22).

Do the high concentrations of several elements, particularly $\mathrm{Ni}, \mathrm{Cu}$, and, $\mathrm{Co}$ at Site 603 , indicate enrichment from hydrothermal sources, as suggested by Lan- 


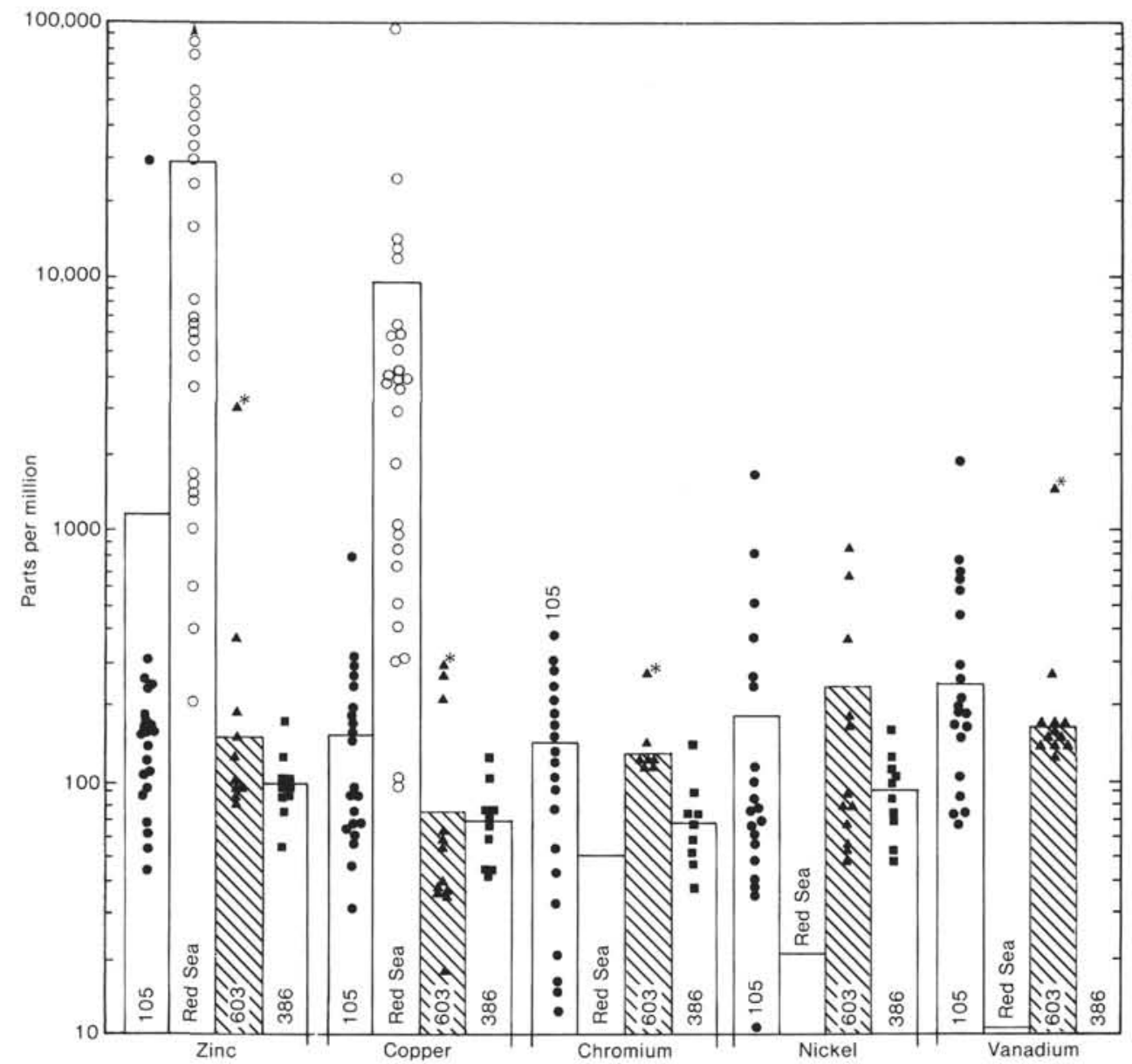

Figure 24. Histograms comparing concentrations of zinc, copper, chromium, nickel, and vanadium in multicolored clays and claystones from DSDP Sites 105, 603, and 386, and hot-brine deposits of the Red Sea. Solid dots are data of Lancelot et al. (1972) for Site 105; open circles are data of Bischoff (1969) and Hendricks et al. (1969) for Red Sea hot-brine deposits; solid triangles are data for Hole 603B (Table 7, this chapter); solid squares are data of Murdmaa et al. (1979) for Site 386. Horizontal bars are mean concentrations. Solid triangle with a star $\left(^{*}\right)$ is Sample 603B-32-1, $61 \mathrm{~cm}$ (Table 7), which has unusually high concentrations of $\mathrm{V}$ and $\mathrm{Zn}$ and was not included in the mean for Hole 603B.

celot et al. (1972)? If they do, then the MCCs should also be enriched in $\mathrm{Mn}$ and $\mathrm{Fe}$ relative to some conservative detrital element such as $\mathrm{Al}$, as is found in the hydrothermal metalliferous sediments of the Bauer Basin and the East Pacific Rise (e.g., Boström and Peterson, 1969; Sayles et al., 1975; Heath and Dymond 1977; Bischoff and Rosenbauer, 1977). Figure 25 shows that the MCCs at Site 603 do not fit this criterion for metalliferous sediments, and that they are similar in composition to normal pelagic clays and most similar to modern red clay on the Hatteras Plain (V26-157). But the high concentrations of some elements and the bands enriched in goethite, manganese oxides, and sphalerite (described by Lancelot et al. [1972] in the MCCs at Site 105), and the high concentrations of $\mathrm{Co}, \mathrm{Ni}$, and $\mathrm{Cu}$ in the MCCs at Site 603 , certainly do require explanation. Because $\mathrm{Fe}, \mathrm{Mn}$, and other elements, particularly the transition elements, are easily mobilized under reducing conditions, Arthur (1979b) hypothesized that much of the excess element concentration in some bands within the MCCs at Site 105 was derived from upward diffusion of dissolved ions and advection of pore waters from compaction of the black shales underlying the MCCs. When the chemically reduced ions derived from the underlying black shales attained a significantly oxidizing interface within the MCCs or at the sediment/water interface, $\mathrm{Fe}$ and/or $\mathrm{Mn}$ oxides precipitated in response to lower solubilities under increased Eh conditions. Arthur (1979b) suggested that sphalerite, which is mainly at the base of the MCCs, also originated by upward diffusion or advection of $\mathrm{Zn}$ in pore waters from the underlying black shales. Sulfur required for sphalerite precipitation could have come from upward-diffusing sulfide from the oxic/suboxic boundary as well.

If the black claystones are the principal source of the metals, and if upward diffusion is the mechanism for transporting these metals, then highest concentrations of metals should be either at the top of the black claystone section or at the base of the overlying MCCs. For example, Dean and Parduhn (1984) presented.evidence that several trace transition elements and $\mathrm{Ba}$ had migrated to the top of the black claystone section at Site 530 in the southern Angola Basin. The section at Site 530 , like that at Site 603 , consists mainly of red and 


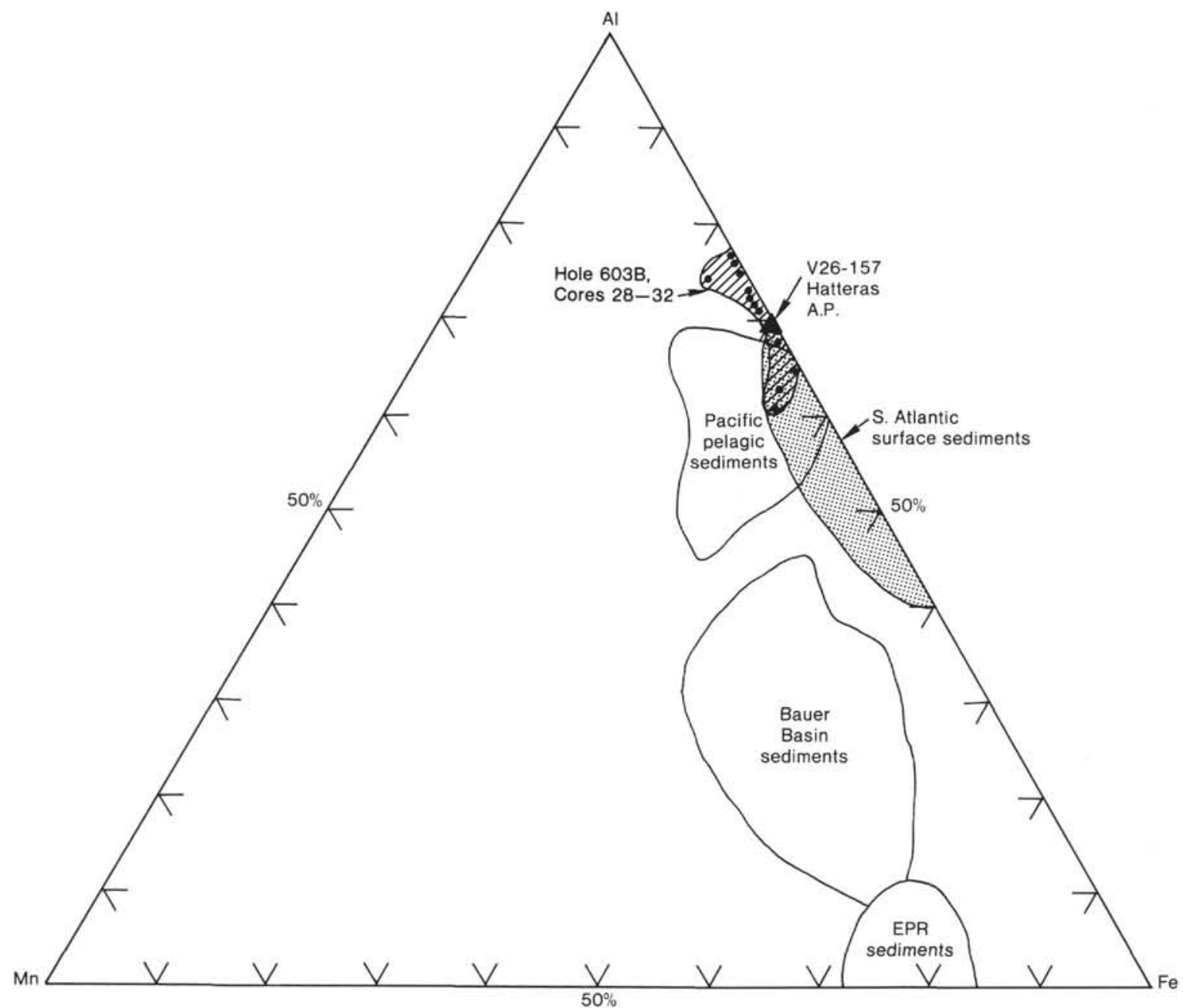

Figure 25. Triangular diagram showing the relative concentrations of $\mathrm{Al}, \mathrm{Mn}$, and $\mathrm{Fe}$ in samples of multicolored claystones from Hole 603B, Cores 28-32 (Table 7, this chapter). Areas representing ranges of concentrations of $\mathrm{Al}, \mathrm{Mn}$, and $\mathrm{Fe}$ in sediments from the Bauer Basin, East Pacific Rise (EPR), and Pacific pelagic sediments are from Bischoff and Rosenbauer (1977). Ranges representing surface pelagic sediments from the South Atlantic are from Boström et al. (1972). A sample of surface red clay (V26-157) from the Hatteras Abyssal Plain southeast of Site 603 is shown for comparison (Table 12; see Fig. 1 for location).

green claystone beds, with some black claystone beds. Dean and Parduhn found that concentrations of $\mathrm{Co}, \mathrm{Cr}$, $\mathrm{Cu}, \mathrm{Mo}, \mathrm{Ni}, \mathrm{V}$, and $\mathrm{Zn}$ generally were higher in black claystone beds in the upper part of the section than in the lower part. The most striking difference was for $\mathrm{Ba}$ concentration, which was considerably higher in all lithologies at the top of the black claystone section. Dean and Parduhn (1984) suggested that the higher concentrations of $\mathrm{Ba}$ and the trace transition elements was due to upward diffusion from the reduced black claystones. Table 3 shows that, with one exception (Sample 603B-28-1, $25 \mathrm{~cm}$ ), the highest concentrations of $\mathrm{Co}, \mathrm{Cu}$, and $\mathrm{Ni}$ occur in samples of green and black claystones at the base of lithologic Unit III (Core 603B-32). Highest concentrations of $\mathrm{V}$ and $\mathrm{Zn}$ also occur in the one black claystone sample from this core (Sample 603B-32-1, 61 $\mathrm{cm})$. These high concentrations of trace transition elements at the base of the MCC section are consistent with reductive remobilization of these sediments as proposed by Arthur (1979b).
If reductive remobilization of metals from the black claystone interval is responsible for the high concentrations of metals in the MCCs, then we are somewhat puzzled that the MCCs at Site 367 (Cape Verde Basin, eastern North Atlantic) are not mineralized and do not contain high concentrations of trace transition elements (Table 12; Fig. 22; Dean and Gardner, 1982), even though the underlying black shales at this site are the richest in marine organic matter and trace elements of any black shales in the Atlantic. This may reflect a sampling problem, however, because the section at Site 367 was only spot cored; the oldest core containing MCCs (Core 36716; Table 12) is separated from the youngest core containing black claystone (Core $367-17$ ) by $66.5 \mathrm{~m}$ of section that was not cored.

\section{Lithologic Unit II-Eocene Radiolarian Claystones}

Lithologic Unit II extends from Core 603B-22 up to Core 603B-15, and includes $63 \mathrm{~m}$ of section. The top $10 \mathrm{~m}$ of this unit (Core 603B-15 and top of Core 603B-16) 
contains particularly brilliant red, orange, and green color variations together with several black beds (Site 603 chapter, this volume). Shipboard observations noted that the black beds were not enriched in OC but rather had high concentrations of manganese. We analyzed four samples from this unit, three from Core 603B-15 and one from Core 603B-16. Table 3 shows that concentrations of most trace elements in these four samples generally are lower than those of the MCCs of lithologic Unit III and the red and green claystones of Unit IV. Sample 603B-15-4, $87 \mathrm{~cm}$ (Table 3 ) does contain higher concentrations of $\mathrm{Co}$ and $\mathrm{Ni}$ (150 and $210 \mathrm{ppm}$, respectively) than most samples listed in Table 12 or plotted in Figure 22 , and would be considered enriched in these elements by most criteria (e.g., the 90th-percentile metal-rich criterion for black shales by Vine and Tourtelot, 1970; Fig. 22). Samples 603B-15-3, $12 \mathrm{~cm}$ and 603B-16-2, $20 \mathrm{~cm}$ contain unusually high concentrations of $\mathrm{Cu}$ (160 and $210 \mathrm{ppm}$, respectively). The one sample of black claystone from Core 603B-16 (Sample 603B-16-2, $20 \mathrm{~cm}$ ) also is enriched in manganese $(1.67 \% \mathrm{MnO})$, which confirms the shipboard observations. We suspect that the high concentrations of several transition elements in several samples from the multicolored claystones of lithologic Unit II were derived from hydrogenous or hydrothermal sources.

\section{CONCLUSIONS}

1. Results of geochemical investigations of the Neocomian carbonates in lithologic Unit V of Hole 603B supported our visual recognition of three lithologic types: bioturbated white limestone; homogeneous, calcareous black claystone; and an intermediate laminated marlstone or limestone. A fourth lithologic type, consisting of coarse clastic turbidites, was not considered in this investigation. The organic matter in the black claystones is low in nitrogen, hydrogen, and phosphorus, and is primarily of terrestrial origin. The carbonate lithologies contain more marine organic matter, as indicated by higher concentrations of hydrogen (higher $\mathrm{HI}$ ) and lighter $\delta^{13} \mathrm{C}$ values. Geochemically, the main distinction between the bioturbated and laminated carbonates is the better degree of preservation of the organic matter in the laminated marlstones and limestones, as manifested by higher $\mathrm{HI}$ values. Comparison of the Neocomian carbonates at Site 603 with those at Site 367 on the other side of the North Atlantic, off Northwest Africa, shows that the organic matter at Site 367 contains more marine organic matter, as indicated by higher values of $\mathrm{HI}$ and lighter values of $\delta^{13} \mathrm{C}$.

2. The Neocomian black claystones have lower $\mathrm{Al}_{2} \mathrm{O}_{3}$ / $\mathrm{TiO}_{2}$ and $\mathrm{Na}_{2} \mathrm{O} / \mathrm{K}_{2} \mathrm{O}$ ratios than either of the carbonate-rich lithologies. These two ratios in the carbonate lithologies at Site 603 trend toward values similar to those for white limestones at Site 367 off Northwest Africa. These compositional differences may reflect mixing of North American and African sources of clastic material in the pelagic carbonates and/or climatic differences between North America and Northwest Africa.

3. The green and black claystones of lithologic Unit IV, like the calcareous black claystones of Unit V, con- tain mostly terrestrial organic matter, as indicated by low values of $\mathrm{HI}$, a $\mathrm{C} / \mathrm{N}$ ratio of 25 , and values of $\delta^{13} \mathrm{C}$ that are mostly between -24 and -26 . The black claystone beds show the expected source trends, in which the more OC-rich beds contain better-preserved, more-marine organic matter with low OI values, high $\mathrm{HI}$ values, and lighter $\delta^{13} \mathrm{C}$ values. The green claystone beds all contain less than $1.0 \%$ OC (and most contain $<0.3 \%$ ), but they are somewhat unusual in that they have a large range of $\mathrm{HI}$ and $\mathrm{OI}$ values. We conclude that the organic matter in the black claystones is more abundant (higher OC content) but generally more degraded (lower HI values and higher $\mathrm{C} / \mathrm{N}$ and $\mathrm{C} / \mathrm{P}$ ratios) than that in the green claystones, and that it is mainly of terrestrial origin, deposited in oxygenated bottom waters. Black claystone beds are most abundant in the Cenomanian part of the section, reaching a maximum at the Cenomanian/Turonian boundary. This period of time is recognized as one of rapid accumulation and burial of OC-rich strata worldwide, in response to increased marine productivity. Before the late Cenomanian, mainly terrestrial organic matter accumulated along the continental margin of North America, and was subsequently redeposited in the deep sea, chiefly by turbidity currents. In response to increased marine productivity worldwide near the $\mathrm{Ce}$ nomanian/Turonian boundary, however, more marine organic matter accumulated in an expanded and intensified oxygen-minimize zone along the continental margin.

4. The black claystone beds at Site 603 are enriched in many trace transition elements relative to average continental crust, average nonblack shale, and average deepsea clay, but they are not enriched in any element relative to Cretaceous black shales from other DSDP sites or from land sections. The samples with highest concentrations of transition metals, especially $\mathrm{V}$ and $\mathrm{Zn}$, occur in the upper Cenomanian part of the section that contains the most marine organic matter.

5. The interbedded black, green, and red claystones of lithologic Unit III are overlain by a unit of only red and green claystones of Late Cretaceous to early Tertiary age, the so-called multicolored claystones of the Plantagenet Formation. This unit is reported to contain high concentrations of several trace transition metals (Lancelot et al., 1972). Compared with metal deposits associated with hot-brine pools in the Red Sea, multicolored claystones from Sites 105 and 603 are enriched in $\mathrm{Cr}, \mathrm{Ni}$, and $\mathrm{V}$, whereas the Red Sea deposits are enriched in $\mathrm{Zn}$ and $\mathrm{Cu}$. Compared with red clay from the adjacent Hatteras Abyssal Plain, the multicolored claystones are enriched in $\mathrm{Cu}$ and $\mathrm{Ni}$. The multicolored claystones are not enriched in Fe and $\mathrm{Mn}$, however, and therefore do not appear to be enriched in metals from hydrothermal sources as was suggested by Lancelot et al. (1972). Excepting the high $\mathrm{Ni}$ and $\mathrm{Cu}$ concentrations, the multicolored claystones are most similar in composition to red clay from the adjacent Hatteras Abyssal Plain. We conclude that the bands of goethite, manganese oxide, and sphalerite described by Lancelot et al. (1972), and any high concentrations of transition metals in the multicolored claystones, are derived from upward diffusion 
from the underlying black claystones of lithologic Unit III.

6. Lithologic Unit II represents a continuation of multicolored clay deposition that began with the deposition of Unit IV. The high concentrations of manganese in the few black claystone beds in this unit, and the particularly brilliant colors of the claystone beds at the top of the unit, suggested that all beds also might be metalrich. Concentrations of most elements in the four samples we analyzed from Unit II generally are lower than those in the multicolored claystones from Unit III or the red claystones of Unit IV. These lower concentrations may be due, in part, to dilution of biogenic silica in the radiolarian claystones of Unit II. One of the four samples we analyzed, however, was enriched in $\mathrm{Co}$ and $\mathrm{Ni}$, and two were enriched in $\mathrm{Cu}$.

\section{ACKNOWLEDGMENTS}

We thank T. A. Daws, C. N. Threlkeld, and A. Vuletich (U.S.G.S.) for providing the Rock-Eval and $\delta^{13} \mathrm{C}$ analyses that appear in Tables 3 and 4; P. Briggs, J. Cornell, and J. Taggert (U.S.G.S.) for providing the XRF and ICP analyses; and S. Hagerty (University of Rhode Island) for performing analyses of OC, T-N, T-S, and $\mathrm{CaCO}_{3}$. M. A. A. acknowledges support from NSF grants OCE 8410178 and 8400622 for part of this study. Critical comments on an the manuscript by $\mathrm{T}$. Anderson, M. Leinen, and G. Claypool are greatly appreciated.

\section{REFERENCES}

Addy, S. K., 1979. Rare earth element patterns in manganese nodules and micronodules from northwest Atlantic. Geochim. Cosmochim. Acta, 43:1105-1115.

Arthur, M. A., 1979a. North Atlantic Cretaceous black shales: The record at Site 398 and a brief comparison with other occurrences. In Sibuet, J.-C., Ryan, W. B. F., et al., Init. Repts. DSDP, 47, Pt. 2: Washington (U.S. Govt. Printing Office), 719-751.

1979b. Origin of Upper Cretaceous multicolored claystones of the western Atlantic. In Tucholke, B. E., Vogt, P. R., et al., Init. Repts. DSDP, 43: Washington (U.S. Govt. Printing Office), 417420.

Arthur, M. A., and Dean, W. E., 1986. Cretaceous paleoceanography of the western North Atlantic Ocean. In Vogt, P. R., and Tucholke, B. E. (Eds.), The Geology of North America (Vol. M): Geol. Soc. Am.

Arthur, M. A., Dean, W. E., Bottjer, D., and Scholle, P. A., 1984. Rythmic bedding in Mesozoic-Cenozoic pelagic carbonate sequences: The primary and diagenetic origin of Milankovitch-like cycles. In Berger, A. L., Imbrie, J., Hays, J., et al. (Eds.), Milankovitch and Climate, Part 1: Amsterdam (Riedel Publishing Co.), pp. 191222.

Arthur, M. A., Dean, W. E., and Claypool, G. E., 1985. Anomalous ${ }^{13} \mathrm{C}$ enrichment in modern marine organic matter. Nature, 315:216218 .

Arthur, M. A., Dean, W. E., and Schlanger, S. O., 1985. Variations in the global carbon cycle during the Cretaceous related to climate, volcanism, and changes in atmospheric $\mathrm{CO}_{2}$. In Sundquist, E. T., and Broecker, W. S. (Eds.), The Carbon Cycle and Atmospheric $\mathrm{CO}_{2}$ : Natural Variations Archean to Present. Am. Geophys. Union Monograph, 32:504-529.

Arthur, M. A., Dean, W. E., and Stow, D. A. V., 1984. Models for the deposition of Mesozoic-Cenozoic fine-grained organic-carbon-rich sediment in the deep sea. In Stow, D. A. V., and Piper, D. J. W. (Eds.), Fine-Grained Sediments: Processes and Products. Geol. Soc. London Spec. Publ., 15:527-559.

Arthur, M. A., and Natland, J. H., 1979. Carbonaceous sediments in the North and South Atlantic: The role of salinity in stable stratification of Early Cretaceous basins. In Talwani, M., Hay, W. W. and Ryan, W. B. F. (Eds.), Deep Drilling Results in the Atlantic Ocean: Continental Margins and Paleoenvironment: Washington (Am. Geophys. Union), Maurice Ewing Ser., 3:297-344.
Arthur, M. A., and Premoli Silva, I., 1982. Development of widespread organic carbon-rich strata in the Mediterannean Tethys. In Schlanger, S. O., and Cita, M. B. (Eds.), Nature and Origin of Cretaceous Carbon-Rich Facies: New York (Academic Press), pp. 7-54.

Arthur, M. A., Schlanger, S. O., and Jenkyns, H. C., 1986. The Cenomanian-Turonian oceanic anoxic event. II. Paleoceanographic controls on organic matter production and preservation. In Brooks, J., and Fleet, A. (Eds.), Marine Petroleum Source Rocks. Geological Soc. London Spec. Publ. 24.

Balistrieri, L., Brewer, P. G., and Murray, J. W., 1981. Scavenging residence times of trace metals and surface chemistry of sinking particles in the deep ocean. Deep-Sea Res., 28A:101-121.

Balistrieri, L. S., and Murray, J. W., 1984. Marine scavenging: Trace metal adsorption by interfacial sediment from MANOP site $\mathrm{H}$. Geochim. Cosmochim. Acta, 48:921-929.

Barron, E. J., 1985. Numerical climate modeling, a frontier in petroleum source rock prediction: Results based on Cretaceous simulations. Am. Assoc. Petrol. Geol. Bull., 69:448-459.

Barron, E. J., and Washington, W. M., 1982. Cretaceous climate: A comparison of atmospheric simulations with the geologic record. Palaeogeogr., Palaeoclimatol., Palaeoecol., 40:103-133.

Beeson, D. C., 1984. The relative significant of tectonics sea-level fluctuations, and paleoclimate to Cretaceous coal distribution in North America [M. S. Thesis]. University of Colorado, Boulder.

Bender, M. L., 1971. Does upward diffusion supply the excess manganese in pelagic sediments? J. Geophys. Res., 76:4214-4215.

Berner, R. A., 1984. Sedimentary pyrite formation-an update. Geochim. Cosmochim. Acta, 48:605-615.

Berner, R. A., and Raiswell, R., 1984. C/S method for distinguishing freshwater from marine sedimentary rocks. Geology, 12:365-368.

Bernoulli, D., 1972. North Atlantic and Mediterranean Mesozoic facies: A comparison. In Hollister, C. D., Ewing, J. I., et al., Init. Repts. DSDP, 11: Washington (U.S. Govt. Printing Office), 801871.

Bischoff, J. L., 1969. Red Sea geothermal brine deposits: Their mineralogy, chemistry and genesis. In Degens, E. T., and Ross, D. A. (Eds.), Hot Brines and Heavy Metal Deposits in the Red Sea: New York (Springer-Verlag), pp. 368-401.

Bischoff, J. L., Heath, G. R., and Leinen, M., 1979. Geochemistry of deep-sea sediments from the Pacific manganese nodule province: DOMES Sites A, B, and C. In Bischoff, J. L., and Piper, D. Z. (Eds.), Marine Geology and Oceanography of the Pacific Manganese Nodule Province: New York (Plenum Press), Marine Science Series, 9:397-436.

Bischoff, J. L., and Rosenbauer, R. J., 1977. Recent metalliferous sediment in the North Pacific manganese area. Earth Planet. Sci. Lett., 33:379-388.

Boström, K., Joensuu, O., and Brohm, I., 1974. Plankton: Its composition and its significance as a source of pelagic sediments. Chem. Geol., 14:255-271.

Boström, K., Joensuu, O., Valdes, S., and Riera, M., 1972. Geochemical history of South Atlantic Ocean sediments since Late Cretaceous. Mar. Geol., 12:85-122.

Boström, K., and Peterson, M. N. A., 1969. The origin of aluminumpoor ferromanganoan sediments in areas of high heat flow on the East Pacific Rise. Mar. Geol., 7:427-447.

Boyle, E. A., 1981. Cadmium, zinc, copper, and barium in Foraminifera tests. Earth Planet. Sci. Lett., 53:11-35.

Boyle, R. W., and Lynch, J. J., 1968. Speculation on the source of zinc, cadmium, lead, copper, and sulfur in Mississippi Valley and similar types of lead-zinc deposits. Econ. Geol., 63:421-422.

Bralower, T. J., and Thierstein, H. R., 1986. Organic carbon and metal accumulation rates in Holocene and mid-Cretaceous marine sediments: Paleoceanographic significance. In Brooks, J., and Fleet, A. (Eds.), Marine Petroleum Source Rocks. Geol. Soc. London Spec. Publ. 24.

Brewer, P. G., and Spencer, D. W., 1974. Distribution of some trace elements in Black Sea and their flux between dissolved and particular phases. In Ross, D. A., and Degens, E. T. (Eds.), The Black Sea-Geology, Chemistry, and Biology. Mem. Am. Assoc. Petrol. Geol., 20:137-142.

Brongersma-Sanders, M., 1965. Metals of Kupferschiefer supplied by normal seawater. Geol. Rundschau, 55:365-375. 
Brongersma-Sanders, M., Stepan, K. M., Kwee, T. G., and de Bruin, M., 1980. Distribution of minor elements in cores from the Southwest Africa shelf with notes on plankton and fish mortality. Mar. Geol., 37:91-132.

Brumsack, H. J., 1980. Geochemistry of Cretaceous black shales from the Atlantic Ocean (DSDP Legs 11, 14, 36, 41). Chem. Geol., 31: $1-25$.

Buffler, R. T., Schlanger, W., et al., 1984. Init. Repts. DSDP, 77; Washington (U.S. Govt. Printing Office).

Calvert, S. E., and Price, N. B., 1970. Minor metal contents of Recent organic-rich sediment off South West Africa. Nature, 227:593-595. 1977. Geochemical variation in ferromanganese nodules and associated sediments from the Pacific Ocean. Mar. Chem., 5:43-74.

Chamley, H., 1979. North Atlantic clay sedimentation and paleoenvironments since the Late Jurassic. In Talwani, M., Hay, W. W., and Ryan, W. B. F. (Eds.), Deep Drilling Results in the Atlantic Ocean: Continental Margins and Paleoenvironment: Washington (Am. Geophys. Union), Maurice Ewing Ser., 3:342-361.

Chamley, H., and Debrabant, P., 1984a. Paleoenvironmental history of the North Atlantic region from mineralogical and geochemical data. Sediment. Geol., 40:151-167.

1984b. Paléoenvironments compares de l'Atlantique nordouest et du Golfe du Mexique oriental, depuis le Jurassic supérieur, d'après les donnes minéralogiques et géochemiques. Bull. Soc. Geol. Fr., 26:71-80.

Chamley, H., Debrabant, P., Candillier, A. M., and Foulon, J., 1983. Clay mineralogical and inorganic geochemical stratigraphy of BlakeBahama Basin since the Callovian, Site 534, Deep Sea Drilling Project Leg 76. In Sheridan, R. E., Gradstein, F. M., et al., Init. Repts. $D S D P, 76$ : Washington (U.S. Govt. Printing Office), 437-451.

Chamley, H., Debrabant, P., Foulou, J., Giroud d'Argoud, G., Latouche, C., Maillet, N., Maillet, H., and Sommer, F., 1979. Mineralogy and quantitative carbonate analysis methods. J. Sediment. Petrol. 50:631-637.

Chester, R., and Aston, S. R., 1976. The geochemistry of deep-sea sediments. In Riley, J. P., and Chester, R. (Eds.), Chemical Oceanography (Vol. 6): New York (Academic Press), 281-390.

Chester, R., Griffiths, A., and Stoner, J. H., 1978. Minor metal contents of surace seawater particulates and organic-rich shelf sediments. Nature, 275:308-309.

Collier, R., and Edmond, J., 1984. The trace element geochemistry of marine biogenic particulate matter. Prog. Oceanogr., 13:113-199.

Corliss, J. B., Lyle, M., Dymond, J., and Crane, K., 1978. The chemistry of hydrothermal mounds near the Galapagos rift. Earth Planet Sci. Lett., 40:12-24.

Cotillon, P., 1984. Tentative world-wide correlation of Early Cretaceous strata by limestone-marl cyclicities in pelagic deposits. Bull. Geol. Soc. Denmark, 33:91-102.

Cotillon, P., and Rio, M., 1984. Cyclic sedimentation in the Cretaceous of Deep Sea Drilling Project Sites 535 and 540 (Gulf of Mexico), 534 (central Atlantic), and in the Vocontian Basin (France). In Buffler, R. T., Schlager, W., et al., Init. Repts. DSDP, 77: Washington (U.S. Govt. Printing Office), 339-376.

Dean, W. E., Arthur, M. A., and Claypool, G. E., $1986 .{ }^{13} \mathrm{C} /{ }^{12} \mathrm{C}$ of organic carbon in Cretaceous deep-sea black shales: Influence of source, diagenesis, and environmental factors. Mar. Geol., 70:119157.

Dean, W. E., Arthur, M. A., and Stow, D. A. V., 1984. Origin and geochemistry of Cretaceous deep-sea black shales and multicolored claystones, with emphasis on Deep Sea Drilling Project Site 530, southern Angola Basin. In Hay, W. W., Sibuet, J.-C., et al., Init. Repts. DSDP, 75, Pt. 2: Washington (U.S. Govt. Printing Office), 819-844.

Dean, W. E., Claypool, G. C., and Thiede, J., 1984. Accumulation of organic matter in Cretaceous oxygen-deficient depositional environments in the central Pacific Ocean. Org. Geochem., 7:39-51.

Dean, W. E., and Gardner, J. V., 1982. Origin and geochemistry of redox cycles of Jurassic to Eocene age, Cape Verde Basin (DSDP Site 367), continental margin of North-west Africa. In Schlanger, S. O., and Cita, M. B. (Eds.), Nature and Origin of Cretaceous Carbon-Rich Facies: New York (Academic Press), pp. 55-78.

Dean, W. E., Gardner, J. V., Jansa, L. F., Cepek, and Seibold, E., 1978. Cyclic sedimentation along the continental margin of North- west Africa. In Lancelot, Y., Seibold, E., et al., Init. Repts. DSDP, 41: Washington (U.S. Govt. Printing Office), 965-986.

Dean, W. E., and Parduhn, N. L., 1984. Inorganic geochemistry of sediments and rocks recovered from the southern Angola Basin and adjacent Walvis Ridge, Sites 530 and 532, Deep Sea Drilling Project Leg 75. In Hay, W. W., Sibuet, J.-C., et al., Init. Repts. DSDP, 75, Pt. 2: Washington (U.S. Govt. Printing Office), 923-958.

Debrabant, P., and Chamley, H., 1982, Influences océaniques et continentales dans les premières dép̂ots de l'Atlantique Nord. Bull. Soc. Geol. Fr., 7:473-486.

Debrabant, P., Chamley, H., and Foulou, J., 1984. Paleoenvironmental implications of mineralogic and geochemical data in the western Florida Straits (Leg 77, Deep Sea Drilling Project). In Buffler, R. T., Schlager, W., et al., Init. Repts. DSDP, 77: Washington (U.S. Govt. Printing Office), 377-396.

Deines, P., 1980. The isotopic composition of reduced organic carbon. In Fritz, P., and Fontes, J. C. (Eds.), Handbook of Environmental Isotope Geochemistry (Vol. 1): Amsterdam (Elsevier), 329 406.

Deroo, G., Herbin, J. P., and Huc, A. Y., 1984. Organic geochemistry of Cretaceous black shales from Deep Sea Drilling Project Site 530, Leg 75, eastern South Atlantic. In Hay, W. W., Sibuet, J.-C., et al., Init. Repts. DSDP, 75, Pt. 2: Washington (U.S. Govt. Printing Office), 983-1000.

Dymond, J., Piper, D. Z., Lyle, M., Finney, B., Murphy, K., Conard, R., and Pisias, N., 1984. Ferromanganese nodules from MANOP Site $\mathrm{H}-$ control of mineralogical and chemical composition by multiple accretionary processes. Geochim. Cosmochim. Acta, 48:931950.

Elderfield, H., and Greaves, M. J., 1982. The rare earth elements in seawater. Nature, 26:214-219.

Elderfield, H., Hawkesworth, C. J., Greaves, M. J., and Calvert, S. E., 1981. Rare earth element geochemistry of oceanic ferromanganese nodules and associated sediments. Geochim. Cosmochim. Acta, 45:513-528.

Espitalié, J., LaPorte, J. L., Madec, M., Marquis, F., Leplat, P., Paulet, J., and Boutefeu, A., 1977. Méthode rapide de caractérisation des roches mères de leur potentiel pétrolier et de leur degré d'évolution. Rev. Inst. Fr. Pet., 32:23-42.

Eugster, H. P., 1985. Oil shales, evaporites, and ore deposits. Geochim. Cosmochim. Acta, 49:619-635.

Floyd, M. A., Fassel, V. A., and D'Silva, A. P., 1980. Computer-controlled scanning monochrometer for the determination of 50 elements in geochemical and environmental samples by inductively coupled plasma-atomic emission spectrometry. Anal. Chem., 52: 2168-2173.

Froelich, P. N., Bender, M. L., Ludetke, N. A., Heath, G. R., and de Vries, T., 1982. The marine phosphorus cycle. Am. J. Sci., 282: 474-511.

Froelich, P. N., Klinkhammer, G. P., Bender, M. L., Luedtke, N. A., Heath, G. R., Cullen, D., Dauphin, P., Hammond, D., Hartman, B., and Maynard, V., 1979. Early oxidation of organic matter in pelagic sediments of the eastern equatorial Atlantic: Suboxic diagenesis. Geochim. Cosmochim. Acta, 43:1075-1090.

Gardner, J. V., Dean, W. E., Klise, D. H., and Baldoff, J. G., 1982. A climate-related oxidizing event in deep-sea sediment from the Bering Sea. Quat. Res., 18:91-107.

Garrison, R. E., 1967. Pelagic limestones of the Oberalm Beds (Upper Jurassic-Lower Cretaceous), Austrian Alps. Bull. Can. Petrol. Geol., 15:21-49.

Glasby, G. P., Keays, R. R., and Rankin, P. C., 1978. The distribution of rare earth, precious metal, and other trace elements in recent and fossil deep sea manganese nodules. Geochem. J., 12:229-243.

Glenn, C. R., and Arthur, M. A., 1985. Sedimentary and geochernical indicators of productivity and oxygen contents in modern and ancient basins: The Holocene Black Sea as the "type" anoxic basin. Chem. Geol., 48:325-354.

Goldberg, E. D., 1957. Biogeochemistry of trace metals. In Hedgepeth, J. W. (Ed.), Treatise on Marine Eology and Paleoeology (Vol. 1). Mem. Geol. Soc. Am., 67:345-357.

Goldberg, E. D., Koide, M., Schmitt, R., and Smith, R., 1963. Rareearth distributions in the marine environment. J. Geophys. Res., 68:4209-4217. 
Goldhaber, M. B., and Kaplan, I. R., 1974. The sulfur cycle in the sea. In Goldberg, E. D. (Ed.), The Sea (Vol. 5): New York (John Wiley), 569-655.

Goldschmidt, V. M., 1958. Geochemistry: London (Oxford Univ. Press).

Goodell, H. G., 1972. Carbon/nitrogen ratio. In Fairbridge, R. W. (Ed.), Encyclopedia of Geochemistry and Environmental Science: New York (Van Nostrand Reinhold), pp. 136-142.

Graciansky de, P. C., Brosse, E., Deroo, G., Herbin, J.-P., Montadert, L., Müller, C., Sigal, J., and Schaaf, A., 1982. Les formations d'âge Crétacé de l'Atlantique Nord et leur matière organique: Paléogéographie et milieux de dépot. Rev. Inst. Fr. Pet., 37: 275-337.

Guichard, F., Church, T. M., Treuil, M., and Jaffrezic, H., 1979. Rare earths in barite: Distribution and effects on aqueous partitioning. Geochim. Cosmochim. Acta, 43:983-97.

Habib, D., 1979. Sedimentary origin of North Atlantic Cretaceous palynofacies. In Talwani, M., Hay, W. W., and Ryan, W. B. F. (Eds.), Deep Drilling Results in the Atlantic Ocean: Continental Margins and Paleoenvironment: Washington (Am. Geophys. Union), Maurice Ewing Ser., 3:420-437.

Hallam, A., 1983. Sedimentation-rate-dependent distribution of organic matter in the North Atlantic Jurassic-Cretaceous. In Sheridan, R. E., Gradstein, F. M., et al., Init. Repts. DSDP, 76: Washington (U.S. Govt. Printing Office), 781-794.

Hallam, A., 1985. A review of Mesozoic climates. J. Geol. Soc. London, 142:433-445.

Haskin, M. A., and Haskin, L. A., 1966. Rare earths in European shales: A redetermination. Science, 154:507-509.

Heath, G. R., and Dymond, J., 1977. Genesis and transformation of metalliferous sediment from the East Pacific Rise, Bauer Deep, and Central Basin, northwest Nazca Plate. Geol. Soc. Am. Bull., 88:723-733.

Hendricks, R. L., Reisbick, F. B., Mahaffey, E. J., Roberts, D. B., and Peterson, M. N. A., 1969. Chemical composition of sediments and interstitial brines from the Atlantis II, Discovery, and Chain deeps. In Degens, E. T., and Ross, D. A. (Eds.), Hot Brines and Recent Heavy Metal Deposits in the Red Sea: New York (SpringerVerlag), pp. 407-440.

Herbin, J. P., and Deroo, G., 1982. Sédimentologie de la matière organique dans les formations du Mésozoic de l'Atlantique Nord. Bull. Soc. Geol. Fr., 7:497-510.

Holland, H. D., 1979. Metals in black shales-a reassessment. Econ. Geol., 74:1676-1680.

1984. The Chemical Evolution of the Atmosphere and Oceans: Princeton (Princeton Univ. Press).

Jacobs, L., Enerson, S., and Skei, J., 1985. Partitioning and transport of metals across the $\mathrm{O}_{2} / \mathrm{H}_{2} \mathrm{~S}$ interface in a permanently anoxic basin: Framvaren Fjord, Norway. Geochim. Cosmochim. Acta, 49: 1433-1444.

Jansa, L. F., Enos, P., Tucholke, B. E., Gradstein, F. M., and Sheridan, R. E., 1979. Mesozoic-Cenozoic sedimentary formations of the North American Basin, western North Atlantic. In Talwani, M., Hay, W. W., and Ryan, W. B. F. (Eds.), Deep Drilling Results in the Atlantic Ocean: Continental Margins and Paleoenvironment: Washington (Am. Geophys. Union), Maurice Ewing, Ser., 3:1-48.

Jansa, L. F., Gardner, J. V., and Dean, W. E., 1978. Mesozoic sequences of the central North Atlantic. In Lancelot, Y., Seibold, E., et al., Init. Repts. DSDP, 41: Washington (U.S. Govt. Printing Office), 991-1010.

Kaplan, I. R., Smith, J. W., and Ruth, E., 1970. Carbon and sulfur concentration and isotopic composition in Apollo 11 lunar samples. Geochim. Cosmochim. Acta, Suppl. 2, pp. 1317-1329.

Katz, B. J., 1983. Limitations of Rock-Eval pyrolysis for typing organic matter. Org. Geochem., 4:195-199.

Kelts, K., and Arthur, M. A., 1981. Turbidites after ten years of Deep Sea Drilling-wringing out the mop? In Warme, J. E., Douglas, R. G., and Winterer, E. L. (Eds.), The Deep Sea Drilling Project: A Decade of Progress. Soc. Econ. Paleontol. Mineral. Spec. Publ., 32:91-127.

Kendrick, J. W., 1979. Geochemical studies of black clays from Leg 43, Deep Sea Drilling Project. In Tucholke, B. E., and Vogt, P. R., et al., Init. Repts. DSDP, 43: Washington (U.S. Govt. Printing Office), 633-642.
Klovan, J. E., and Miesch, A. T., 1976. Extended CABFAC QMODEL computer programs for Q-mode factor analysis of compositional data. Comp. Geosci., 1:161-178.

Knauer, G. A., and Martin, J. H., 1973. Seasonal variations of cadmium, copper, manganese, lead, and zinc in water and phytoplankton in Monterey Bay, California. Limnol. Oceanogr., 18:597-604.

Krauskopf, K. B., 1956. Factors controlling the concentrations of thirteen rare metals in seawater. Geochim. Cosmochim. Acta, 9:1-32.

Krom, M. D., and Berner, R. A., 1981. The diagenesis of phosphorus in a nearshore marine sediment. Geochim. Cosmochim. Acta, 45: 207-216.

Lancelot, Y., Hathaway, J. V., and Hollister, C. D., 1972. Lithology of sediments from the western North Atlantic, Leg 11, Deep Sea Drilling Project. In Hollister, C. D., Ewing, J. I., et al., Init. Repts. DSDP, 11: Washington (U.S. Govt. Printing Office), 901-950.

Leinen, M., and Stakes, D., 1979. Metal accumulation rates in the central equatorial Pacific during Cenozoic time. Geol. Soc. Am. Bull., 90:357-375.

Leventhal, J. S., 1980. Comparative geochemistry of Devonian shale cores from the Appalachian Basin, Mason, Monongalia, and Upsure counties, West Virginia; Illinois Basin, Tazwell County, Clark County, Indiana; and Michigan Basin, Sanilac County, Michigan. U.S. Geol. Surv. Open-File Rept., 80-938.

1983. An interpretation of carbon and sulfur relationships in Black Sea sediments as indicators of environments of deposition. Geochim. Cosmochim. Acta, 47:133-137.

Leventhal, J. S., Briggs, P. H., and Baker, J. W., 1984. Geochemistry of the Chattanooga Shale, DeKalb County, central Tennessee. Southeastern Geol., 24:101-116.

Leventhal, J. S., Crock, J. R., and Malcolm, M. J., 1981. Geochemistry of trace elements and uranium in Devonian shales of the Appalachian Basin. Final report to U.S. Department of Energy for the Eastern Gas Shales Program. U.S. Geol. Surv. Open-File Rept., 81-778.

Leventhal, J. S., and Hosterman, J. W., 1982. Chemical and mineralogical analysis of Devonian black-shale samples from Martin County, Kentucky; Caroll and Washington counties, Ohio; Wise County, Virginia; and Overton County, Tennessee, U.S.A. Chem. Geol., 37:239-264.

Lewan, M. D., and Maynard, J. B., 1982. Factors controlling enrichment of vanadium and nickel in the bitumen of organic sedimentary rocks. Geochim. Cosmochim. Acta, 46:2547-2560.

Li, Y.-H., 1982. Interelement relationship in abyssal Pacific ferromanganese nodules and associated pelagic sediments. Geochim. Cosmochim. Acta, 46:1053-1060.

Li, Y.-H., Bischoff, J. L., and Mathieu, G., 1969. The migration of manganese in the Arctic Basin sediment cores. Earth Planet. Sci. Lett., 7:265-270.

Lynn, D. C., and Bonatti, E., 1965. Mobility of manganese in diagenesis of deep-sea sediments. Mar. Geol., 3:457-474.

McCave, I. N., 1979a. Depositional features of organic black and green mudstones at DSDP Sites 386 and 387, western North Atlantic. In Tucholke, B. E., Vogt, P. R., et al., Init. Repts. DSDP, 43: Washington (U.S. Govt. Printing Office), 411-416.

1979b. Diagnosis of turbidites at Site 386 and 387 by particle-counter size analysis of the silt $(2-40 \mu \mathrm{m})$ fraction. In Tucholke, B. E., Vogt, P. R., et al., Init. Repts. DSDP, 43: Washington (U.S. Govt. Printing Office), 395-405.

Martin, J. H., and Knauer, G. A., 1973. The elemental composition of plankton. Geochim. Cosmochim. Acta, 37:1639-1653.

Meyers, P. A., Brassell, S. C., and Huc, A. Y., 1984. Geochemistry of organic carbon in South Atlantic sediments from Deep Sea Drilling Project Leg 75. In Hay, W. W., Sibuet, J.-C., et al., Init. Repts. DSDP, 75, Pt. 2: Washington (U.S. Govt. Printing Office), 967-981.

Moore, C., and Boström, K., 1978. The elemental composition of lower marine organisms. Chem. Geol., 23:1-9.

Muller, P. J., 1977. C/N ratios in Pacific deep-sea sediments: Effect of inorganic ammonium and organic nitrogen compounds sorbed by clays. Geochim. Cosmochim. Acta, 41:765-776.

Muller, P. S., and Suess, E., 1979. Productivity, sedimentation rate, and sedimentary organic carbon content in the oceans. Deep-Sea Res., 26:1347-1362.

Murdmaa, I. O., Gordeev, V. V., Emelyanov, E. M., Shirshov, P. P., and Bazilevskaya, E. S., 1979. Inorganic geochemistry of Leg 43 
sediments. In Tucholke, B. E., Vogt, P. R., et al., Init. Repts. DSDP, 43: Washington (U.S. Govt. Printing Office), 675-694.

Orr, W. L., 1981. Comments on pyrolytic hydrocarbon yields in sourcerock evaluation. In Advances in Organic Geochemistry: London (John Wiley and Sons), pp. 775-787.

1983. Comments on pyrolytic hydrocarbon yields in sourcerock evaluation, In Advances in Organic Geochemistry: London (John Wiley and Sons), pp. 775-787.

Owen, R. M., and Rea, D. K., 1985. Sea-floor hydrothermal activity links climate to tectonics: The Eocene carbon dioxide greenhouse. Science, 277:166-169.

Parrish, J. T., and Curtis, R. L., 1982. Atmospheric circulation, upwelling, and organic-rich rocks in the Mesozoic and Cenozoic eras. Palaeogeogr., Palaeoclimatol., Palaeoecol., 40:31-66.

Parrish, J. T., Ziegler, A. M., and Schotese, C. R., 1982. Rainfall patterns and the distribution of coals and evaporites in the Mesozoic and Cenozoic. Palaeogeogr., Palaeoclimatol., Palaeoecol., 40:67101.

Pederson, T. F., and Price, N. B., 1982. The geochemistry of manganese carbonate in Panama Basin sediments. Geochim. Cosmochim. Acta., 46:59-68.

Piper, D. Z., 1974. Rare earth elements in ferromanganese nodules and other marine phases. Geochim. Cosmochim. Acta, 38:10071022 .

Piper, D. Z., and Graef, P. A., 1974. Gold and rare-earth elements in sediments from the East Pacific Rise. Mar. Geol., 17:287-297.

Pratt, L. M., 1985. Isotopic studies of organic matter and carbonate in rocks of the Greenhorn marine cycle. In Pratt, L. M., Kauffman, E. G., and Zelt, F. B. (Eds.), Fine-grained Deposits and Biofacies of the Cretaceous Western Interior Seaway: Evidence of Cyclic Sedimentary Processes. Soc. Econ. Paleontol. Mineral., Fieldtrip Guidebook, No. 4:38-48.

Pratt, L. M., and Threlkeld, C. N., 1984. Stratigraphic significance of ${ }^{13} \mathrm{C} /{ }^{12} \mathrm{C}$ ratios in mid-Cretaceous rocks of the western interior, U.S.A. In Stott, D. F., and Glass, D. J. (Eds.), Mesozoic of Middle North America. Mem. Can. Petrol. Geol., 9:305-312.

Robertson, A. H. F., and Bliefnick, D. M., 1983. Sedimentology and origin of Lower Cretaceous pelagic carbonates and redeposited clastics, Blake-Bahama Formation, Deep Sea Drilling Project Site 534, western equatorial Atlantic. In Sheridan, R. E., Gradstein, F. M., et al., Init. Repts. DSDP, 76: Washington (U.S. Govt. Printing Office), 795-828.

Sayles, F. L., Ku, T. K., and Bowker, P. C., 1975. Chemistry of ferromanganoan sediment of the Bauer Deep. Geol. Soc. Am. Bull., 86:1423-1431.

Schlanger, S. O., Arthur, M. A., Jenkyns, H. C., and Scholle, P. A., 1986. The Cenomanian-Turonian oceanic anoxic event, 1. Stratigraphy and distribution of organic-carbon-rich beds and the marine $\delta^{13} \mathrm{C}$ excursion. In Brooks, J., and Fleet, A. (Eds.), Marine Petroleum Source Rocks. Geol. Soc. London Spec. Publ. 24.

Schlanger, S. O., and Jenkyns, H. C., 1976. Cretaceous oceanic anoxic events-causes and consequences. Geol. Mijnbouw, 55:179-184.

Scholle, P. A. (Ed.), 1977. Geological studies on the COST No. B-2 well, U.S. Mid-Atlantic outer continental shelf area. U.S. Geol. Surv. Circ., 750.

1979. Geological studies of the COST GE-1 well, United States South Atlantic outer continental shelf area. U.S. Geol. Surv. Circ., 800 .

1980. Geological studies of the COST No. B-3 well, United States Mid-Atlantic continental slope area. U.S. Geol. Surv. Circ., 833.

Scholle, P. A., and Arthur, M. A., 1980. Carbon isotope fluctuations in Cretaceous pelagic limestones: Potential stratigraphic and petroleum exploration tool. Am. Assoc. Petrol. Geol. Bull., 64:67-87.

Scholle, P. A., and Wenkam, C. R. (Eds.), 1982. Geological studies of the COST Nos. G-1 and G-2 wells, United States North Atlantic outer continental shelf. U.S. Geol. Surv. Circ., 861.

Schwarzacher, W., and Fischer, A. G., 1982. Limestone-shale bedding and perturbations of the earth's orbit. In Seilacher, A., and Einsele, G. (Eds.), Cyclic and Event Stratification: Berlin (SpringerVerlag), pp. 72-95.
Shearme, S., Cronan, D. S., and Rona, P. A., 1983. Geochemistry of sediments from the TAG hydrothermal field, M. A. R. at latitude $26^{\circ}$ N. Mar. Geol., 51:269-291.

Suess, E., 1979. Mineral phases in anoxic sediments by microbial decomposition of organic matter. Geochim. Cosmochim. Acta, 43: 339-352.

1981. Phosphate regeneration from sediments of the Peru continental margin by dissolution of fish debris. Geochim. Cosmochim. Acta, 45:577-588.

Summerhayes, C. P., 1981. Organic facies of middle Cretaceous black shales in the deep North Atlantic. Am. Assoc. Petrol. Geol. Bull., 65:2364-2380.

1986. Organic-rich Cretaceous sediments from the North Atlantic. In Brooks, J., and Fleet, A. J. (Eds.), Marine Petroleum Source Rocks. Geol. Soc. London Spec. Publ., 24.

Summerhayes, C. P., and Masran, T. C., 1983. Organic facies of Cretaceous and Jurassic sediments from DSDP Site 534 in the BlakeBahama Basin, western North Atlantic. In Sheridan, R. E., Gradstein, F. M., et al., Init. Repts. DSDP, 76: Washington (U.S. Govt. Printing Office), 469-480.

Taggert, J. E., Wahlberg, J. S., and Taylor, H. E., 1980. X-ray spectrometric major-element analyses of tephra samples from the May 18, 1980 eruption of Mount St. Helens-samples collected from Washington, Idaho, and Montana. U.S. Geol. Surv. Open-File Rept., $80-1130$.

Thierstein, H. R., 1979. Paleoceanographic implications of organic carbon and carbonate distribution in Mesozoic deep-sea sediments. In Talwani, M., Hay, W. W., and Ryan, W. B. F. (Eds.), Deep Drilling in the Atlantic Ocean: Continental Margins and Paleoenvironment: Washington (Am. Geophys. Union), Maurice Ewing Ser., 3:249-274.

Tissot, B. P., Demaison, G., Masson, P., Delteil, J. R., and Combaz, A., 1980. Paleoenvironment and petroleum potential of middle Cretaceous black shales in the Atlantic basin. Am. Assoc. Petrol. Geol. Bull., 64:2051-2063.

Tissot, B. P., Deroo, G., and Herbin, J. P., 1979. Organic matter in Cretaceous sediments of the North Atlantic: Contribution to sedimentology and palaeogeography. In Talwani, M., Hay, W. W., and Ryan, W. B. F. (Eds.), Deep Drilling Results in the Atlantic Ocean: Continental Margins and Paleoenvironment: Washington (Am. Geophys. Union), Maurice Ewing Ser., 3:362-374.

Tissot, B. P., and Welte, D. H., 1978. Petroleum Formation and Occurrence: New York (Springer-Verlag).

Tourtelot, H. A., 1964. Minor-element composition and organic carbon content of marine and nonmarine shales of Late Cretaceous age in the western interior of the United States. Geochim. Cosmochim. Acta, 28:1579-1604.

Tucholke, B. E., and Mountain, G. S., 1979. Seismic stratigraphy, lithostratigraphy and paleosedimentation patterns in the North American Basin. In Talwani, M., Hay, W. W., and Ryan, W. B. F. (Eds.), Deep Drilling Results in the Atlantic Ocean: Continental Margins and Paleoenvironment: Washington (Am. Geophys. Union), Maurice Ewing Ser., 3:58-86.

Tucholke, B. E., and Vogt, P. R., 1979. Western North Atlantic: Sedimentary evolution and aspects of tectonic history. In Tucholke, B. E., Vogt, P. R., et al., Init. Repts. DSDP, 43: Washington (U.S. Govt. Printing Office), 791-825.

Turekian, K. K., 1972. Chemistry of the Earth: New York (Holt, Rinehart, and Winston).

Turekian, K. K., Katz, A., and Chan, L., 1973. Trace elements trapping in pteropod tests. Limnol. Oceanogr., 18:240-249.

Uchupi, E., 1971. Bathymetric atlas of the Atlantic, Caribbean, and Gulf of Mexico, Woods Hole Oceanographic Inst. Ref. No. 71-72 (unpublished manuscript).

Vine, J. D., and Tourtelot, E. B., 1969. Geochemical investigations of some black shales and associated rocks. U.S. Geol. Surv. Bull., 1314-A.

1970. Geochemistry of black shale deposits-a summary report. Econ. Geol., 65:253-272.

Vinogradov, A. P., 1953. The elementary composition of marine organisms. Mem. Sears Found. Mar. Res., 2. 
Volkov, I. I., and Fomina, L. S., 1974. Influences of organic materials and processes in deep-water sediments of the Black Sea. In Degens, E. T., and Ross, D. A. (Eds.), The Black Sea-Geology, Chemistry, and Biology. Mem. Am. Assoc. Petrol. Geol., 20:457476 .

Walsh, J., Premuzic, E. T., Gaffney, J. S., Rowe, G. T., Harbottle, G., Stoenner, R. W., Balsam, W. L., Betzer, P. R., and Macko, S. A., 1985. Organic storage of $\mathrm{CO}_{2}$ on the continental slope off the MidAtlantic bight, the southeastern Bering Sea, and the Peru coast. Deep-Sea Res., 32:853-883.

Waples, D. W., 1985. Organic and inorganic nitrogen in sediment from Leg 80, Deep Sea Drilling Project. In Graciansky, P. C. de, Poag, C. W., et al., Init. Repts. DSDP, 80: Washington (U.S. Govt. Printing Office), 993-998.
Wedepohl, K. H., 1964. Untersuchung am Kupferschiefer in nordwest Deutschland; ein Beitrag zur Deutung der Genese bituminoger Sediment. Geochim. Cosmochim. Acta, 28:305-364. ston).

1971. Geochemistry: New York (Holt, Rienhart, and Win-

Weissert, H., 1982. The environment of deposition of black shales in the Early Cretaceous: An ongoing controversy. In Warme, J. E., Douglas, R. G., and Winterer, E. L. (Eds.), The Deep Sea Drilling Project; A Decade of Progress. Soc. Econ. Paleontol. Mineral. Spec. Publ., 32:547-560.

Date of Initial Receipt: 23 July 1985 Date of Acceptance: 25 February 1986 